Luiz Francisco Sanfilippo

\title{
EPIDEMIOLOGIA E CARACTERIZAÇÃO MOLECULAR DO VÍRUS DA INFLUENZA EM QUATRO ESPÉCIES DE PINGUINS NA REGIÃo ANTÁRTICA
}

Tese apresentada ao Programa de PósGradação em Microbiologia no Instituto de Ciências Biomédicas da Universidade de São Paulo para obtenção do Título de Doutor em Ciências.

São Paulo

2010 


\section{EPIDEMIOLOGIA E CARACTERIZAÇÃO MOLECULAR DO VÍRUS DA INFLUENZA EM QUATRO ESPÉCIES DE PINGUINS NA REGIÃo ANTÁRTICA}

Tese apresentada ao Programa de Pós Graduação em Microbiologia no Instituto de Ciências Biomédicas da Universidade de São Paulo, para obtenção do Título de Doutor em Ciências.

Área de Concentração: Microbiologia Orientador: Prof. Dr. Walderez Gambale 
DADOS DE CATALOGAÇÃO NA PUBLICAÇÃO (CIP)

Serviço de Biblioteca e informação Biomédica do

Instituto de Ciências Biomédicas da Universidade de São Paulo

(c) reprodução total

Sanfilippo, Luiz Francisco.

Epidemiologia e caracterização molecular do vírus da influenza em quatro espécies de pinguins na região antártica / Luiz Francisco Sanfilippo.- São Paulo, 2010.

Orientador: Walderez Gambale.

Tese (Doutorado) - Universidade de São Paulo. Instituto de Ciências Biomédicas. Departamento de Microbiologia. Área de concentração: Microbiologia. Linha de pesquisa: Virologia.

Versão do titulo para o inglês: Epidemiology and molecular characterization of the influenza virus in four penguin species of the antartic region.

Descritores: 1. Influenza aviária 2. Vigilância epidemiológica 3. Caracterização molecular 4.Virologia molecular 5. Antártica 6. Pinguim I. Gambale Walderez II. Universidade de São Paulo. Instituto de Ciências Biomédicas. Programa de Pós-Graduação em Microbiologia. III. Título 


\section{UNIVERSIDADE DE SÃO PAULO \\ INSTITUTO DE CIÊNCIAS BIOMÉDICAS}
Candidato(a):
Luiz Francisco Sanfilippo
Título da Tese:
Epidemiologia e caracterização molecular do vírus da influenza em quatro espécies de pinguins da região antártica.

Orientador(a): $\quad$ Dr. Walderez Gambale

.A Comissão Julgadora dos trabalhos de Defesa da Tese de Doutorado, em sessão pública realizada a ..................., considerou

\section{( ) Aprovado(a) \\ ( ) Reprovado(a)}

Examinador(a): Assinatura:

Nome:

Instituição:

Examinador(a): Assinatura:

Nome:

Instituição:

Examinador(a): Assinatura:

Nome:

Instituição:

Examinador(a): Assinatura:

Nome:

Instituição:

Presidente: Assinatura:

Nome:

Instituição: 
Universidade de São Paulo Instituto de Ciências Biomédicas

Departamento de Microbiologia Laboratório de Virologia Clínica e Molecular
Av. Prof, Lineu Prestes, 1374

05508-900 - Säo Paulo - SP Brasil

Tel: (011) 3091-7293

Fax. (011) $3091-7354$

São Paulo, 15 de Março de 2010

IImo. Sr

Prof Dr. José Cipolla Neto

Presidente da Comissão de Pós-Graduação ICB/USP

EU, LUIZ FRANCISCO SANFILIPPO, $n^{\circ}$ USP 1143102 , aluno regularmente matriculado do Curso de Pós-Graduação em Microbiologia do Instituto de Ciências Biomédicas, nível DOUTORADO, venho por meio desta solicitar, para efeitos de exame geral de qualificação e de defesa de Tese, a equivalência das licenças 201/2006 da CGFAUIBAAMA com certificado concedido pela Comissão de Ética em Pesquísas com Animais número CEP $122 / 04$ para o projeto intíulado SSOROEPIDEMIOLOGIA E CARACTERIZAGÃO MOLECULAR DO VIRUS DA FEBRE DO OESTE DO MLO "WEST NILE FEVER VIRUS" NAS REGIÖES TROPICAL E SUB-TROPICAL DO BRASIL, e licencas do Programa Antártico Brasileiro - PROANTAR do período de $14 / 11 / 2006$ a 08/03/2007 para o projeto em QXecUÇão EPIDEMIOLOGIA E CARACTERIZAGEOO MOLECULAR DO VIRUS DA 


\section{INFLUENZA EM QUATRO ESPÉCIES DE PINGUINS NA REGIÃO ANTARTICA",}

em virtude da mudança do local de coleta das amostras e do objetivo previamente definido para a referida tese.

Outrossim ressaltamos que a metodologia utilizada para a coleta do material permaneceu a mesma, com coleta de sangue, swab oral e cloacal e que não houve sacrificio dos animais As licenças pertinentes à coleta do material a ser estudado encontram-se anexas a este oficio.

\section{Atenciosamente,}

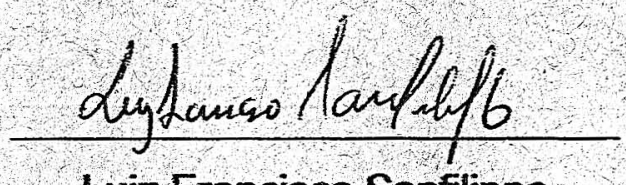

Luiz Francisco Sanfilippo No USP 1143102

Instituto de Ciências Biomédicas

Universidade de São Paulo

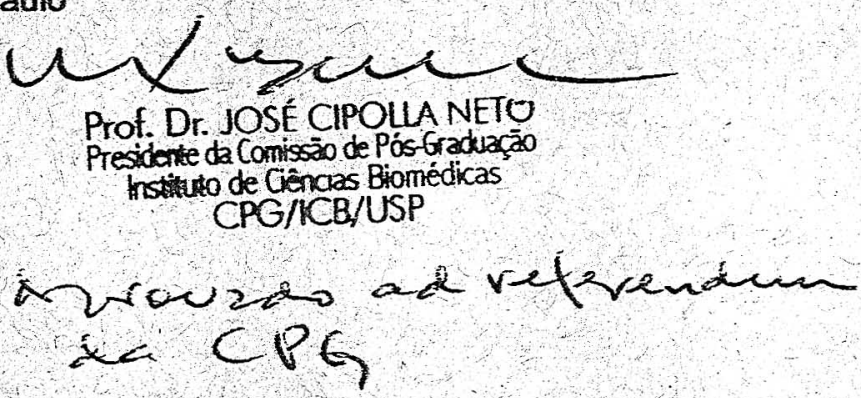




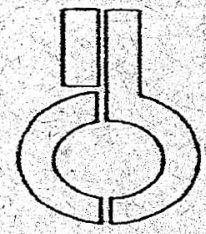

\section{Certificado}

Certificamos que o protocolo registrado sob $n^{\circ} 122$ nas fls. 10 do livro 2 para uso de animais em experimentação, sob a responsabilidade do Prof. Dr. Edison Luiz Durigon, Coordenador da Linha de Pesquisa "Soroeptderniologia e caractelzacão molecular do virus da febre do Oeste do Nilo "West Nile Fever Vírus" nas regiōes tropical e subtropical do Brasit do qual participou(aram) o(s) aluno(s): Luiz Francisco Sanfilippo está de acordo com os Princípios Éticos de Experimentaşão Animal adotado pelo Colégio Brasileiro de Experimentação Animal (COBEA) e foi aprovado pela COMISSÃO DE ÉTICA EM EXPERMENTAÇĀO ANMAL (CEEA) em 23.11.2004.

São Paulo, 24 de novembro de 2004.

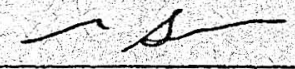

Profa. Dra. Marilia C. Leite Seelaender Coordenadora da CEEA

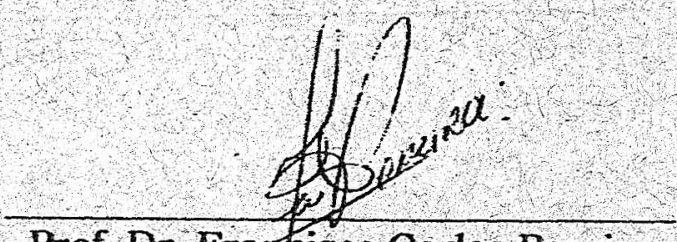

Prof. Dr. Francisco Carlos Pereira Secretário da CEEA

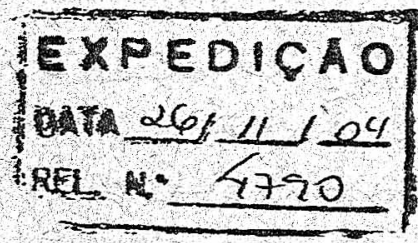




\section{PROGRAMA ANTÁRTICO BRASILEIRO - PROANTAR}

\section{LICENÇA}

Em conformidade com o Art.3 do Anexo II ao Protocolo do Tratado da Antártica sobre Proteção ao Meio Ambiente e com as Medidas para Conservaçāo da Fauna e Flora Antárticas adotadas pela ATCM, esta LICENGA autoriza os pesquisadores do projeto Microbiologia Antártica: Biodiversidade, Ecologia e Aplicasóos Tecnológicas, listados abaixo a proceder a captura e coleta de material biológico de aves antárticas: Pinguins Gentoo (Pygoscelis papua), Adelie (Pygoscelis adeliae) e Antártico (Pygoscelis antarctica); Skua (Chataracta sp); e Gaivotóes (Larus dominicanus). Os pesquisadores também estżo autorizados a coletar animais (aves e mamiferos marinhos) que venham a ser encontrados mortos por causas naturais, para a detecçao de virus de importancia zoonótica.

VIVIAN HELENA PELLIZARI

CRISTINA ROSSI NAKAYAMA

IARSEN DE ARAÚJO

LEANDRO HELGUEIRA DE ANDRADE

LUIZ FRANCISCO SANFILIPPO

RUBENS DUARTE

UA CARDOSO R. SARAIVA TEIXEIRA

LUZ HENRIQUE ROSA

MÁRIO LUIS FIGUEIREDO

ROSALINDA CARMELA MONTONE

Local: Bata do Almirantado, Itha Rei George

Periodo: $14 /$ NOVI2006 a 08INAR/2007
RUBENS CÉSAR LOPES FIGUEIRA

ALEXANDRE SOARES ROSADO

ANDRES OCHOA

CESAR DE CASTRO MARTINS

RAFAEL ANDRÉ LOURENCO

WILI IAM JOSÉ FERREIRA

LUIS RENATO DE SOUZA

GERALDO JOSÉ SAMZANEZ

JULIANA NODA BECHARA BELO

IRARCELO KRINGS

Brasilia - DF, 19 de outubro de 2006
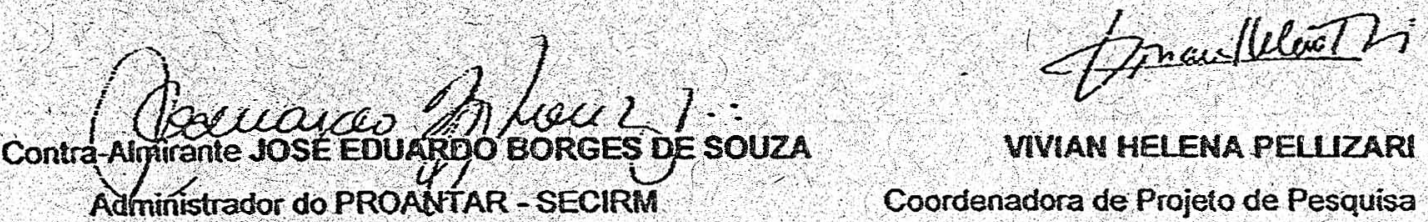

Coordenadora de Projeto de Pesquisa

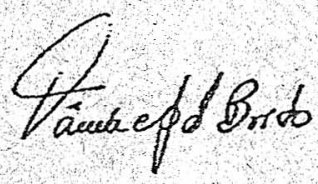

TANIA APARECIDA SILVA BRITO

Coordenadora do Grupo de Avaliação Ambiental - MMA 
O solicitante declara ser responsável por todas as informaçōes prestadas neste formulário. Declara também conhecer os lermos do Plano de Gerenciamento da Área Antártica Especialmente Protegida, assim como está cienie da exigéncia de portar uma cópía da presente Licenfa, enquanto permanecer no interior da Área, e de apresentar um Relatório de Visita no término da mesma, de acordo com o Protocolo do Tratado da Aníúrtida sobre Proteção do Meio Ambiente, internalizado na legislação nacional pelo Decreto Legislativo $N^{\circ} 8811995$.

Data: São Paulo, 29 de setembro de 2006.

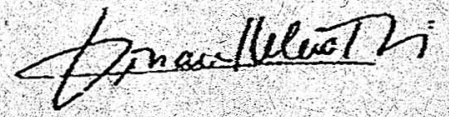

Dra. Vivian Helena Pellizari

Responsável pelo Projeto de Pesquisa

Autorização:

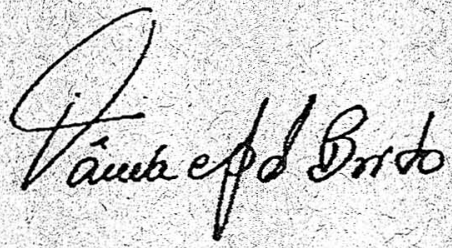

Dra Tânia Aparecida Silva Brito

Coordenadora

Grupo de Avaliação Ambiental do PROANTAR - GAAm/MMA

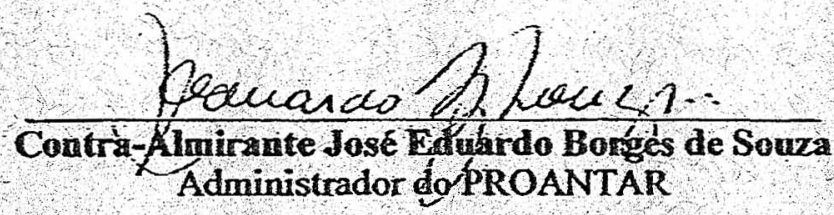




\section{Área Antártica Especialmente Protegida \\ LICENÇA PARA VISITACĀO}

13. Comentários ou informaçōes adicionais, se necessárias:

1. Para o preenchimento do presente formulario foram consultados os seguintes documentos:

- Scar Code of Conduct for the use of animals for scientific purposes in Antarctica

- Protocol on Environmental Protection to the Antarctic Treaty (1991) - anexo 2, artigo 3 ("Protection of native fauns and flora').

- Management Plan for Site of Special Scientific Interest Number 8

2. O especialista em aves que compáe a equipe é o pesquisador Luiz Francisco Sanfilippo, que possui extensa experiência na área, tendo trabalhado em diversos ecossistemas no Brasil e no exterior, incluindo pingtineiras.

O solicitanle declara ser responsável por todas as informaföes prestadas neste formulário. Declara lambém conhecer os termos do Plano de Gerenciamento da Area Antártica Especialmente Protegida, assim como está ciente da exigéncia de portar uma cópia da presente lícença, enquanto permanecer no interior da Área, e de apresentar um Relatório de Visita no término da mesma, de acordo com o Protocolo ao Tratado da Antártida sobre Protecão do Meio Ambiente, internalizado na legislação nacional pelo Decreto Legislativo $N^{\circ} 88 / 1995$.

O solicitante está autorizado a coletar animais mortos (aves e mamiferos marinhos) para amostragem de tecidos e a visitar as d́reas de nidificação das aves para procurar e coletar ovos gorados, bem como filhotes mortos, desde que seja acompanhado por especialístas da área e desde que todo cuidado seja tomado para não perturbar os animais das colônias visitadas.

Data: São Paulo, 29 de setembro de 2006.

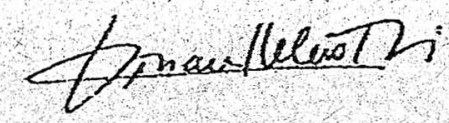

Dra. Vivian Helena Pellizari

Responsável pelo Projeto de Pesquisa

Autorização:

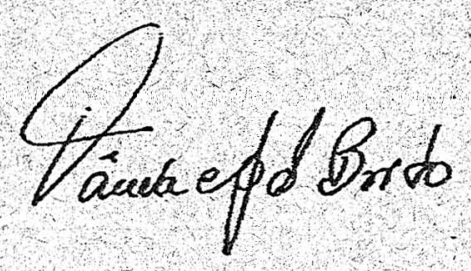

\section{Dra Tânia Aparecida Silva Brito}

Coordenadora do GAAm/MMA

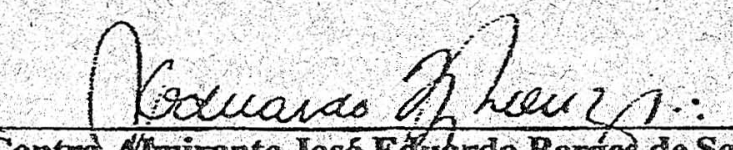

Contra- fhairante Jose Ed dusirdo Borges de Souza

Administrador do PROANTAR 


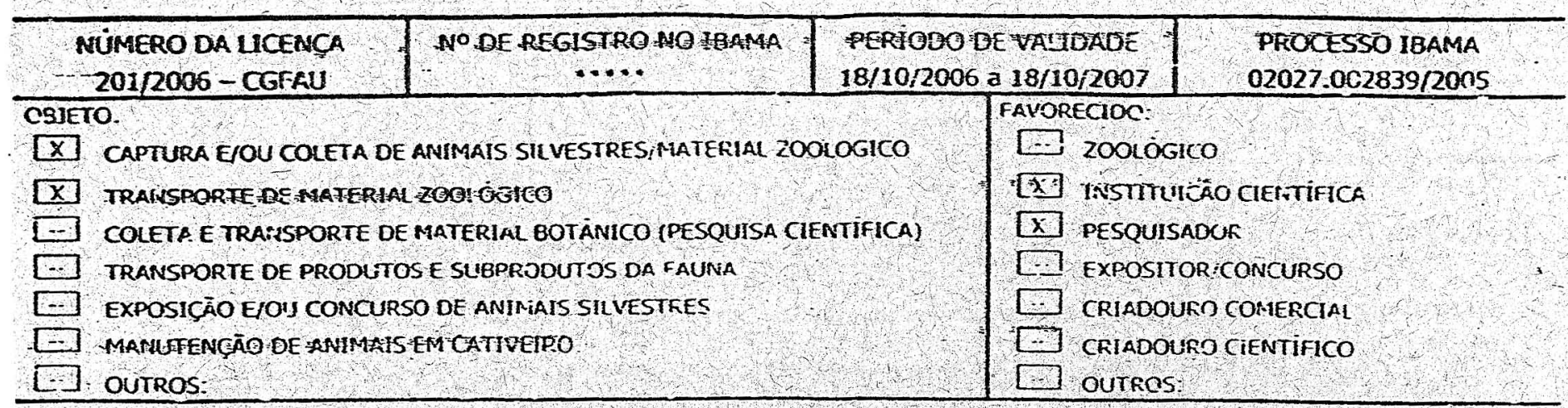

\section{FAVORECIDOS}

NOME(S): Edison Luiz Durigon, Luiz Francisco Sanfiqpo. Iilgue! Auquslo Golone, Jangen de Aräijo. Felipe Atves Morais e Carolina de Souza Ferreira.

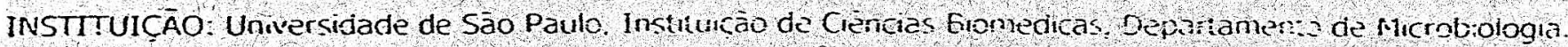

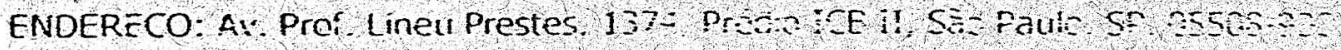

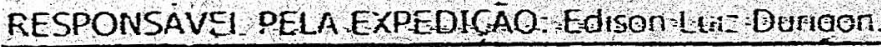

- NSPORTADOR: PESquisadores favorecidos.

1-IEIO DE TRRNSPORTF: Terrestre/ AEREO : Fluvia:

PROCEDÉNCIALLOCAL DA CAPTURAILOLAL DA PESQUJiSÁ: ESTado de Sä́ PaulC E Fondäne

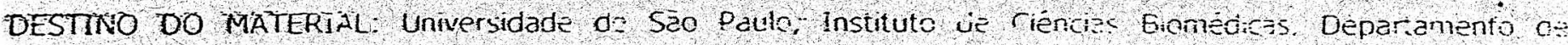
Microbiología.

LISTA DAS ESFECIES
QUANTIDADE I TIPO

Captura, marcação e coleta ' " " Inderteminado

Captura sejuida de soltura para marcacão e coleta de dados

biométricos, sangue e fezes / $\wedge$ Irderteminado

Copitora seguiáa de soltura para coleta de dados biométricos. tnque fezes e secrecão oral e doacal / $\mathrm{N}^{\circ}$ Inderteminado

\section{NOME CISNTIFICC}

HORIE COR IUH

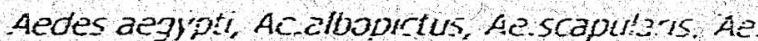
seitatus, Culex quinquéasciaxus, Cx. Nigripalpus.

Cxmelanoconion, Cogulettria senezuelensis, Mensonia sn. psoropho.atero.

Rodentie, Harsetia's = Quroptere

Fordures, marsupiais 6 morcegos

Avitaune

fives

\section{OBSERUACOEES E CONOTCTONANTES:}

1. A autorizacão de anilhamento deverá ser solicitada peló aniliador sénior, membro da expedicão, ao centro Lacional de Pesouisa para Conservacāo das Aves Sivestres (CEMAVE) atraves do Sistema liacional d. Anilhamento SNA net hitp:www ibama.gov.br/cemave

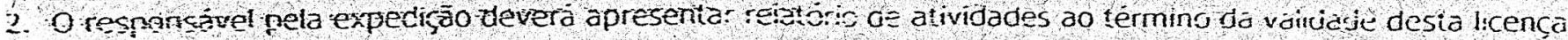

3. O responsável pela expedicäo devera encaminhar ao lueme cajia dos frontispicios das publicasöes, rasultante.,

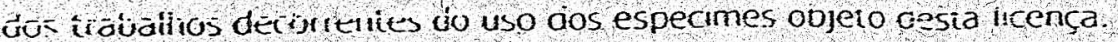

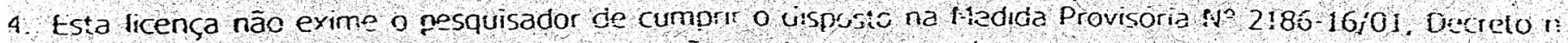
$3945 / 2001$ e Decreto $\AA^{\circ} 4.946 / 2003$ que dispocm sobrc o acesso de comporiente do patrimönio geneico.

5. Esta licença permite o transporte de amostras de Flavivirus, Alphavjrós e Bunyavirus da faculdade de Medicina da USP de Ribeirão Preto e do Instituto Evandro Chagas. Fuñeá̧āo Nácional de Saude, Belém, Pará para u Instituto de Ciéncias Biomédicas, USP.

OUAL CDAADE ETISSTS

3rasilia (DF). 18 de outubro de 2006 
Aos meus pais Miguel e Therezinha, que sempre me incentivaram e apoiaram em todas as decisões e projetos da minha vida.

Aos meus irmãos Antônio, Maria e Lúcia por estarem sempre ao meu lado.

A minha querida futura esposa Celina por seu apoio constante em todos os momentos.

Ao meu avô Manoel por ter me guiado sempre pelos difíceis caminhos. 


\section{AGRADECIMENTOS}

Agradeço a todas as pessoas que direta ou indiretamente contribuíram para a execução deste trabalho, em especial,

Minha mãe Therezinha Domingos Sanfilippo meu pai Miguel Sanfilippo, meus irmãos Antônio, Maria e Lúcia, meus cunhados Claudio, Armin e Maria Helena, meus sobrinhos Rafael, Vinícius, Mariana e Gabriela que além da dedicatória têm minha eterna gratidão.

Aos meus grandes amigos Carlos Yamashita e Antonio Audi por terem sempre me guiado.

Ao prof. Edison L. Durigon que mais do que um orientador, se mostrou um grande amigo.

A todos os integrantes da equipe de campo do Laboratório de Virologia Clínica e Molecular do Instituto de Ciências Biomédicas da Universidade de São Paulo (ICB-USP): Jansen de Araújo, Carolina Ferreira, Renata Hurtado, Tatiana Ometto, José Maria Lopes, Miguel Golono, Cristiane Demetrio, Mário Figueiredo, Luciano Thomazelli, Ricardo Lieutaud, e a equipe de suporte: Dani, Lílian e Juliana.

Aos amigos pesquisadores Silvana Favoretto, Adélia Kawamoto, Luiz Eloy Pereira pelo exemplo que sempre tentarei seguir.

A amiga Angélica Cristine de Almeida Campos, pela enorme força e paciência.

A Jacinta pelos vários puxões de orelha.

Aos meus amigos Emanuelle e Azis por sempre terem me ajudado.

Aos Ilmos. membros da minha banca examinadora de qualificação:

Todos os amigos do Laboratório de Virologia - USP: Andréa, Ariane, César, Claudionor, Danila, Eduardo, Maria Paula, Cláudia, Dyana, Fábio, Felipe, Gustavo, Hildener, Jean, Larissa, Lilia, Patrícia, Thereza, Raquel, Vivian,Daniele, Camila, Raquel...

Ao meu orientador Prof. Dr.Walderez Ganbale, pelo apoio e amizade.

Ao amigo Joaquim O. Branco, pela ajuda durante as Expedições Antárticas.

À marinha do Brasil e o programa PROANTAR pelo suporte à Expedição Antártica.

Á Gaia Consultoria pela compreensão.

Aos secretários da pós Graduação da USP, Alice e Bruno

Às funcionárias da Biblioteca do ICB, Monica e Eva.

Aos profissionais da secretaria de microbiologia pelo apoio em tudo.

E por fim, por tudo, à mulher da minha vida Celina Keiko Yoshihara. 
"Procuram-se homens para perigosa viagem. Salário reduzido. Frio penetrante. Muitos meses de completo escuro. Constante perigo. Regresso são e salvo duvidoso. Honra e reconhecimento em caso de êxito"

Ernest Shackleton 


\section{RESUMO}

Sanfilippo LF. Epidemiologia e caracterização molecular do vírus da influenza em quatro espécies de pinguins da região antártica [tese (Doutorado em Microbiologia)]. São Paulo: Instituto de Ciências Biomédicas da Universidade de São Paulo; 2010.

O vírus da influenza, apesar de todas as epidemias e pandemias referirem-se a infecções em seres humanos, não está restrito a espécie humana e é capaz de causar debilidade ou mortalidade em várias outras espécies, incluindo cavalos, suínos, mamíferos marinhos e aves, entre outros. Estudos ecológicos das viroses por influenza conduziram à hipótese que todas as que acometem mamíferos derivam de reservatórios destes vírus em aves. Mesmo com programas de monitoramento contínuo de aves silvestres em alguns países do mundo que possuem casos originados pelos vírus aviário $\mathrm{H} 5 \mathrm{~N} 1$, pouco foi feito na Antártica, e por isso, o presente trabalho foi realizado nas estações de verão antártico de 2006, 2007 e 2008 em duas localidades no território Antártico, a Península Keller, localizada na Ilha Rei George e na ilha Elefante $61^{\circ} 08^{\prime} \mathrm{S}, 55^{\circ} 07^{\prime} \mathrm{W}$, a primeira onde está situada a Estação Antártica Comandante Ferraz-EACF e a segunda onde está localizada uma base de apoio a estudos avançados. Para este estudo foi realizada a coleta de 283 amostras de quatro diferentes espécies de pinguins: Pygoscelis adeliae; P. papua; P. antarctica; Aptenodytes patagonicus. Para o diagnóstico das amostras colhidas, foi aplicada a detecção direta dos produtos amplificados pelo método de RT-PCR em gel de agarose confirmados pelo método de Real-Time PCR (Applied Biosystems) e pelo RT-PCR-GeneScan no laboratório de Virologia Clínica e Molecular, do Departamento de Microbiologia, da Universidade de São Paulo. Os resultados obtidos em nosso estudo foram 8 amostras positivas em pinguins para o vírus Influenza A. As amostras positivas por RT-PCR, e as outras amostras coletadas, foram encaminhadas para o laboratório de Influenza do Department of Infectious Diseases, St. Jude Children's Research Hospital, Memphis, TN, USA, para isolamento em ovos embrionados, não havendo crescimento de vírus da influenza A. Quatro destas amostras positivas puderam ser sequenciadas e comparadas com sequências de Influenza A depositadas no GenBank apresentando uma identidade de $96,8 \%$ a $100 \%$ entre elas e o controle tendo este último uma identidade de $100 \%$ com as do banco de dados, confirmando a presença do vírus nestas aves.

Palavras-chave: Influenza aviária. Vigilância Epidemiológica. Caracterização Molecular. Virologia Molecular. Antártica. Pinguim. 


\begin{abstract}
Sanfilippo LF. Epidemiology and molecular characterization of the influenza virus in four penguin species of the antartic region. [Ph. D. thesis (Microbiology)]. São Paulo: Institute of Biomedical Sciences of the University of São Paulo; 2010.

Epidemics and pandemics of influenza usually refer to infections in human beings. The influenza virus is not, however, restricted to humans and can cause infirmity and death in other species-including horses, swine, marine mammals, birds, and others. Ecological studies of viral infections have led to the hypothesis that the influenza viruses that attack mammals have their origin in the accumulation of these viruses in birds (avian flu). In some countries with influenza cases caused by the avian H5N1 virus, there was monitoring of wild birds but little had been done in Antarctica. The present work was therefore carried out during the Antarctic summer seasons of 2006, 2007, and 2008 in two Antarctic locations: The Commander Ferraz Antarctic Station, on the Keller Peninsula of King George Island, and at the Base of Advanced Studies located on Elephant Island $\left(61^{\circ} 08^{\prime} \mathrm{S}, 55^{\circ} 07^{\prime} \mathrm{W}\right)$. Two hundred eighty-three (283) samples from four different penguin species-Pygoscelis adeliae, Pygoscelis papua, Pygoscelis antarctica; and Aptenodytes patagonicus-were collected for this study. Diagnoses of the samples were performed not only by application of direct detection and amplification according to the RT-PCR method in agar-gel, but also by RealTime PCR (Applied Biosystems), and by RT-PCR gene scan at the Laboratory of Clinical and Molecular Virology of the Department of Microbiology of the University of Sao Paulo. Eight of the penguin samples tested positive for the Influenza-A virus. The positive samples, as determined by RT-PCR, and the others samples, were sent to the Influenza Laboratory of the Department of Infectious Diseases of the St. Jude Research Hospital in Memphis, Tennessee, USA, to be isolated in egg embryos - where no further growth of the Influenza-A virus took place. Four of these positive samples could be sequenced and compared with those of Influenza-A on deposit at the GenBank and ranged from 96.85 to $100 \%$-when compared with the control samples (100\% positive), thus confirming the presence of the virus in the tested birds.
\end{abstract}

Key words: Avian flu. Epidemiological. Surveillance. Molecular. Characterization. Molecular virology. Antartic. Penguin. 


\section{LISTA DE ILUSTRAÇÕES}

Figura 1- Micrografia eletrônica de transmissão do vírus de Influenza................................ 18

Figura 2- Mapa demonstrando a pandemia de influenza em 1918 ...................................... 19

Figura 3 - Modelo estrutural do vírus da influenza do tipo A...........................................21

Figura 4 - Ciclo de vida do vírus da Influenza. ............................................................. 23

Figura 5 - Reservatórios do vírus de influenza A. ............................................................. 27

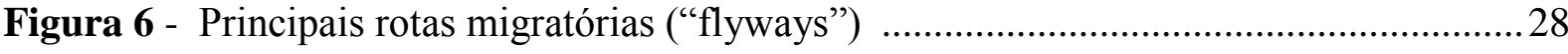

Figura 7 - Distribuição das espécies de pinguins no continente ............................................30

Figura 8 - Estrutura colocada a disposição pelo Programa Antártico Brasileiro utilizada para a

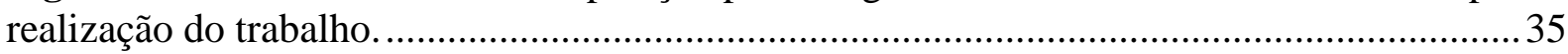

Figura 9 - Imagem de satélite mostrando a localização da Estação Brasileira Comandante Ferraz, na Ilha Rei George, ponta da grande Península Antártica......................................... 36

Figura 10 - Mapa da Ilha Rei George mostrando a localização da Estação Brasileira Comandante Ferraz e os pontos de coleta de material em Punta Plaza, Punta Heinnequin,

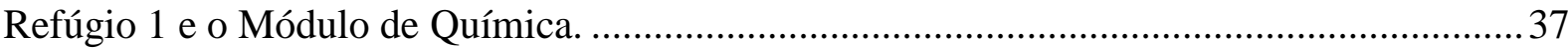

Figura 11 - Imagem de satélite mostrando a localização da Ilha Elefante ............................ 38

Figura 12 - Mapa da Ilha Elefante mostrando a localização do Refúgio para Estudos e o

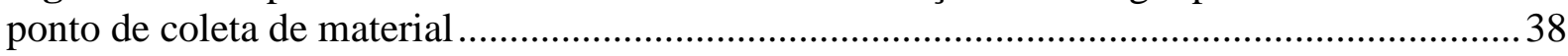

Figura 13 - Vista parcial da Ilha Elefante quando da chegada com o helicóptero..................39

Figura 14 - Captura de exemplar de pinguim, próximo ao módulo de química.....................40

Figura 15 - Utilização de zaragatoa para coleta de material oral.......................................... 41

Figura 16 - Retirada de sangue da artéria femoral............................................................ 41

Figura 17 - Laboratório do módulo de química, Ilha Rei George........................................42

Figura 18 - Barraca laboratório (vermelha e branca) próximo ao refúgio, Ilha Elefante........ 42

Figura 19 - Pinguim marcado antes da soltura com tinta atóxica..........................................43

Figura 20 - Sequência completa do gene NS do segmento 8. ................................................ 45 
Figura 21 - Sequência completa dos genes M1 e M2 contidos no segmento 7 46

Figura 22 - Ovos marcados e prontos para a inoculação.

Figura 23 - A- Lixadeira portátil utilizada para fazer a abertura na casca dos ovos e permitir a entrada da agulha na cavidade alantóica. B- Inoculação de ovos embrionados com $2 \mu \mathrm{L}$ de amostra.

Figura 24 - Placas de Petri contendo ágar sangue para a execução dos testes de esterilidade dos cultivados.

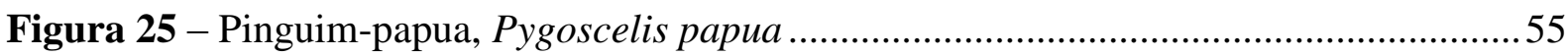

Figura 26 - Pinguim-adélia, Pygoscelis adeliae .............................................................56

Figura 27 - Pinguim-antártico, Pygoscelis antarctica. .......................................................56

Figura 28 - Pinguim- rei, Aptenodytes patagonicus. .......................................................57

Figura 29- Proporção entre as espécies de pinguins amostradas durante o verão Antártico de 2006/2007.

Figura 30 - Proporção entre as espécies de pinguins amostradas durante o verão Antártico de $2007 / 2008$

Figura 31 - Proporção entre as espécies de pinguins amostradas durante o verão Antártico de $2008 / 2009$

Figura 32 - Proporção entre as espécies de pinguins amostradas nos três verões antárticos..61

Figura 33 - Resultado positivo do RT - PCR com leitura em gel de agarose (amostra 16/06 de Pygoscelis adeliae).

Figura 34 - Resultado do PCR em Tempo Real da amostra 86/06, demonstrando em vermelho a curva de amplificação do controle positivo e em azul a curva de amplificação da amostra. 65

Figura 35 - Resultado do PCR GeneScan da amostra 16/06, demonstrando em vermelho a curva de amplificação do controle positivo e em azul a curva de amplificação da amostra. ...66

Figura 36 - Comparação entre as sequências de nucleotídeos indicam uma similaridade entre as sequências obtidas e as do controle.

Figura 37 - Árvore filogenética de máxima verossimilhança (maximum likelihood), 68

Figura 38 - Resultados obtidos em uma das placas realizadas para o teste de hemaglutinação.

Figura 39 - Teste rápido para a amostra 35. 


\section{LISTA DE TABELAS}

Tabela 1 - Sequencias obtidas no GeneBank do segmento 8 do vírus da influenza A utilizadas para comparação com as amostras positivas de pinguins.

Tabela 2 - Número de pinguins amostrados por espécie no verão antártico de 2006/2007. ...57

Tabela 3 - Número de pinguins amostrados por espécie no verão antártico de 2007/2008 ...58

Tabela 4 - Número de pinguins amostrados por espécie no verão antártico de 2008/2009. ...59

Tabela 5 - Número de pinguins amostrados por espécie nas três estações de verão antártico.60

Tabela 6 - Amostras com resultado positivo testadas pelo método de PCR com visualização em gel de agarose

Tabela 7 - Tabela das 35 amostras que apresentaram bandas fracas e foram novamente testadas pelo método de PCR com visualização em gel de agarose.

Tabela 8 - Matriz comparativa da identidade verificada entre as amostras positivas para influenza A e o controle positivo H1N1. 


\section{LISTA DE ABREVIATURAS E SIGLAS}

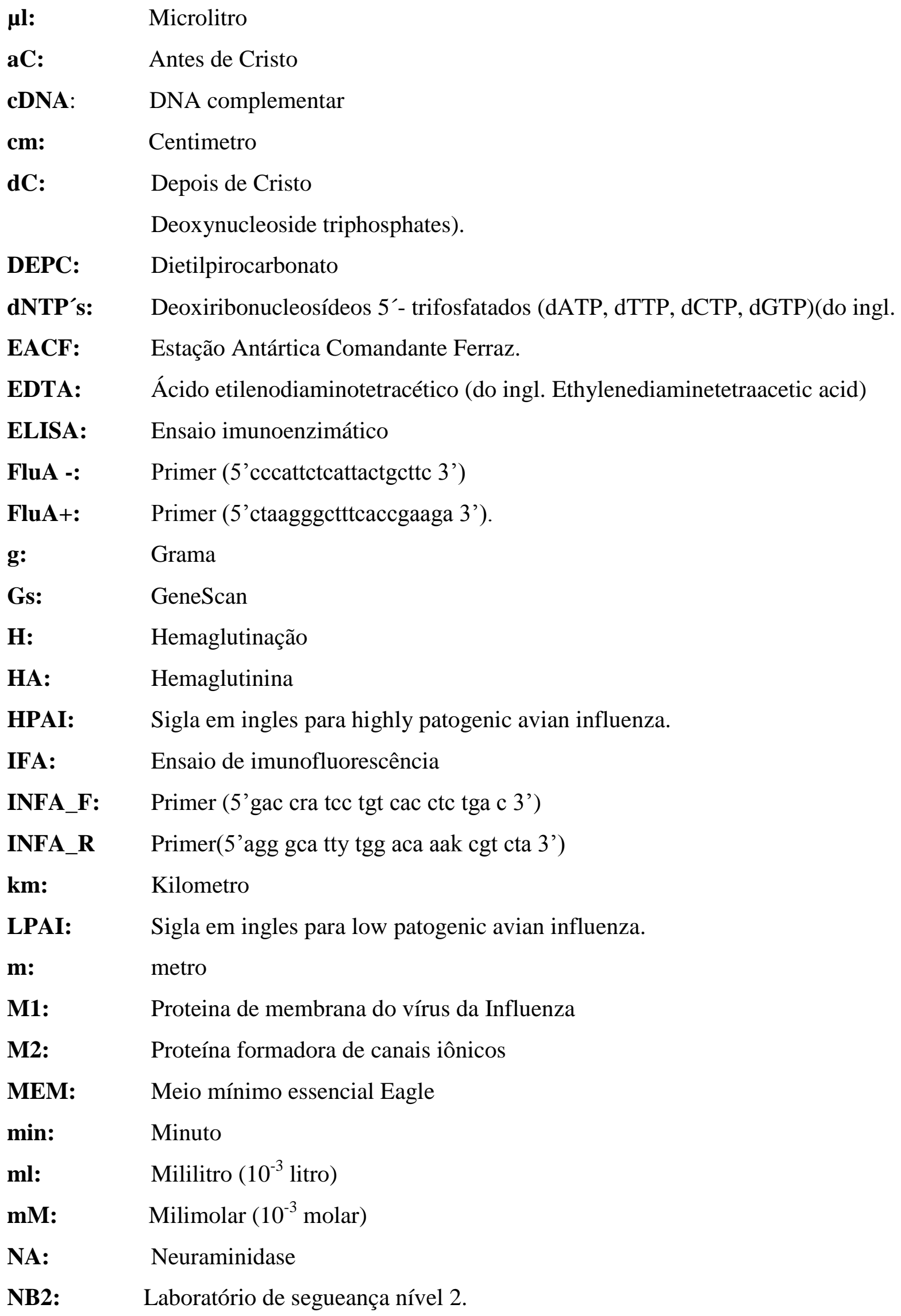

IFA: $\quad$ Ensaio de imunofluorescência

INFA_F: Primer (5' gac cra tcc tgt cac ctc tga c 3')

INFA_R Primer(5'agg gca tty tgg aca aak cgt cta 3')

km: $\quad$ Kilometro

LPAI: $\quad$ Sigla em ingles para low patogenic avian influenza.

m: metro

M1: $\quad$ Proteina de membrana do vírus da Influenza

M2: Proteína formadora de canais iônicos

MEM: $\quad$ Meio mínimo essencial Eagle

min: $\quad$ Minuto

ml: $\quad$ Mililitro $\left(10^{-3}\right.$ litro $)$

mM: $\quad$ Milimolar $\left(10^{-3}\right.$ molar $)$

NA: Neuraminidase

NB2: $\quad$ Laboratório de segueança nível 2. 
NP: Nucleoproteína

NS1: Proteína viral com função não estrutural, mas sim tradutora e transportadora.

NS2: Proteína viral com função desconhecida.

nt: $\quad$ Nucleotídeos

pb: $\quad$ Pares de bases

PB1: $\quad$ Proteína viral transcriptase de alongamento, codificada pelo seguimento 2

PB2: $\quad$ Proteína viral transcriptase de ligação, codificada pelo seguimento 1

PBS: $\quad$ Solução salina tamponada com fosfatos

PCR: $\quad$ Reação em cadeia pela polimerase

pH: Potencial hidrogeniônico

pmoles: Picomol $\left(10^{-12} \mathrm{~mol}\right)$

primer: $\quad$ Oligonucleotídeo iniciador

q.s.p: $\quad$ Quantidade sufuciente para

RNA: $\quad$ Ácido Ribonucléico

RNAc: $\quad$ RNA complementar

RNAm: $\quad$ RNA mensageiro

RNAse: $\quad$ Ribonuclease

RNAv: $\quad$ Ácido Ribonucléico viral

RNAv: $\quad$ RNA viral

RT: $\quad$ Transcrição reversa

RT-PCR: Reação em cadeia pela polimerase após transcrição reversa

S: Segundo

TAE: $\quad$ Solução tampão com 40 mM Tris-acetato pH 8,0,1 mM EDTA- Ácido etilenodiaminotetracético

Tris: $\quad$ Tris (hydroxymethyl) aminomethane

U: $\quad$ Unidade

URF: $\quad$ Unidade Relativa de Fluorescência

USP: $\quad$ Universidade de São Paulo

UV: Ultravioleta

V: $\quad$ Volts 


\section{LISTA DE SÍMBOLOS}

Bases nitrogenadas dos nucleotídeos

Adenina...

a

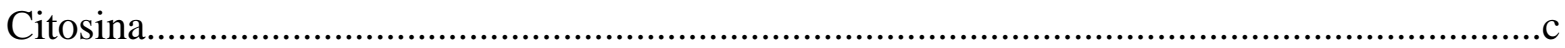

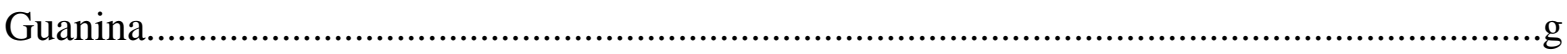

Timina 


\section{SUMÁRIO}

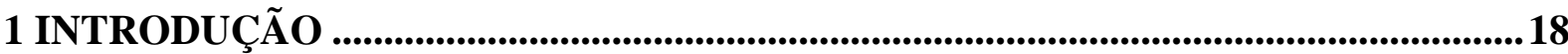

2 JUSTIFICATIVA E RELEVÂNCIA ........................................................................... 32

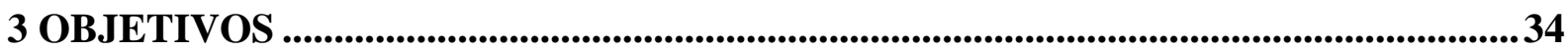

4 MATERIAL E METODOS

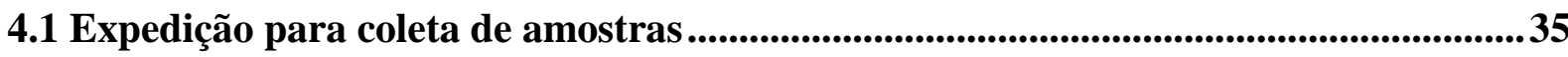

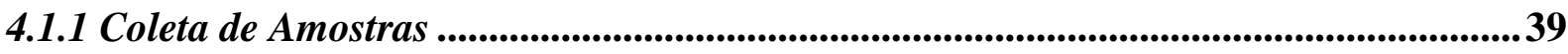

4.2 Extração de RNA das Amostras Virais ..................................................................................43

4.3 Transcrição Reversa.................................................................................................................43

4.4 Reacões de PCR para a Detecção Viral ........................................................................ 44

4.5 Eletroforese em Gel de Agarose ......................................................................................................45

4.6 PCR em Tempo Real .............................................................................................................................. 45

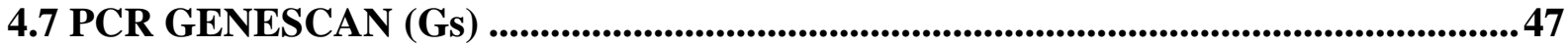

4.7.1 Detecção dos Produtos Amplificados .............................................................................................. 47

4.8 Sequenciamento do Material Genético ...................................................................48

4.8.1 - Processamento e alinhamento das sequências obtidas com as do segmento 8 do vírus da influenza $A$.............................................................................................................................................. 48

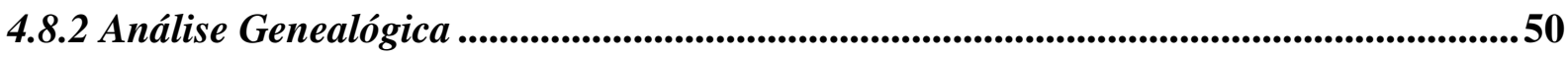

4.9 Inoculação em ovos embrionados...................................................................................5

4.9.1 Preparação dos Antibióticos ..................................................................................................50

4.9.2 Preparação dos Ovos e Inoculação .......................................................................................51

4.9.3 Colheita do material incubado ....................................................................................52

4.9.4 Teste de esterilidade ...................................................................................................................52

4.9.5 Teste de Hemaglutinação ......................................................................................................53

4.9.6 Teste rápido para detecção de influenza ............................................................................54

5 RESULTADOS ..................................................................................................................................55

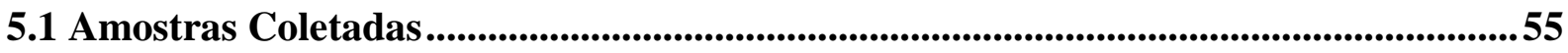

5.2 Detecção Viral Através da Reação de PCR ........................................................................61

5.3 Detecção Viral Através do PCR em Tempo Real .....................................................664

5.4 Detecção Viral Através de Técnica de GeneScan ..........................................................65 
5.5 Sequenciamento ……….......................................................................................................................66

5.5.1 Analise genealógica .......................................................................................................................67

5.6 Inoculação em Ovos Embrionados........................................................................................69

5.6.1 Teste de esterilidade ........................................................................................................................69

5.6.2 Teste de hemaglutinação ...........................................................................................................69

5.6.3 Teste rápido para detecção de influenza ................................................................................70

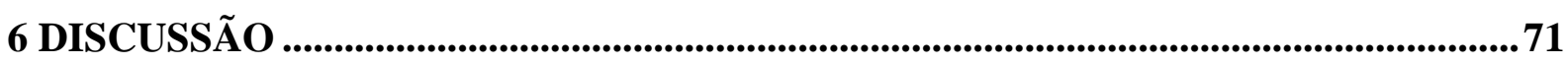

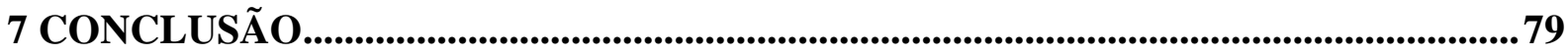

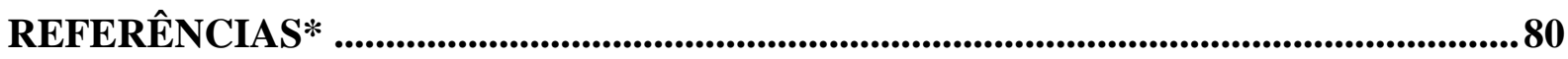

APÊNDICE A - Tabela do resultado do total de amostras testadas pelo método de PCR com visualização em gel de agarose, PCR em Tempo Real, GeneScan e confirmadas por sequenciamento.............................................................................................................................86 


\section{INTRODUÇÃO}

A gripe, uma doença respiratória aguda causada pelo vírus da influenza, foi disseminada pelas populações humanas há muitos séculos. É definida como uma doença de alta patogenicidade, particularmente atacando o sistema respiratório sendo transmitida pela inalação de perdigoto proveniente de organismos infectados, causando periódicas epidemias e pandemias (Kuszewski e Brydak, 2000).

A Influenza é considerada um paradigma das doenças virais, principalmente por possuir características que proporcionam uma continua evolução do vírus causador e primordialmente pela sua importância em gerar epidemias anuais - ocasionalmente pandemias - em animais e na população humana. (Webster et al., 1992)

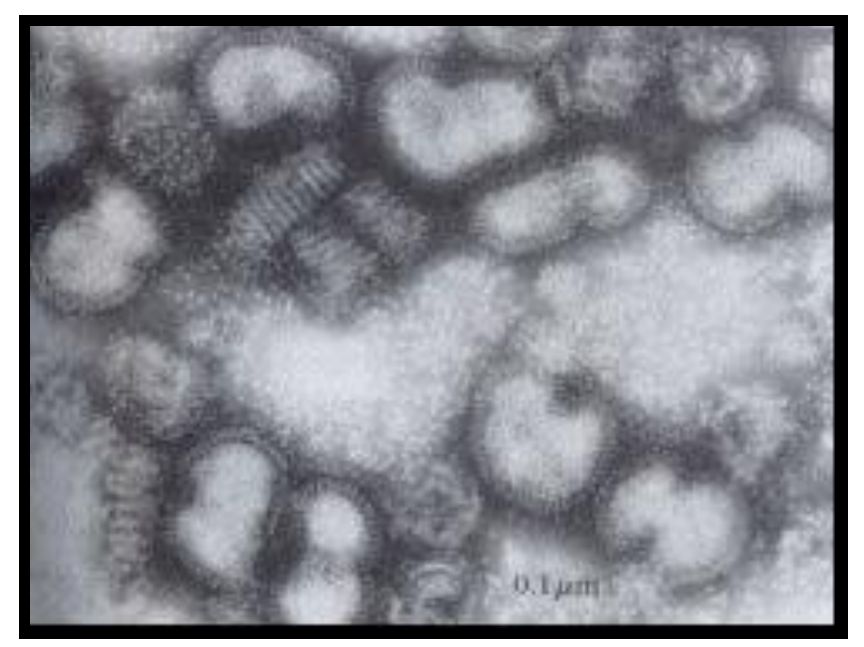

Figura 1- Micrografia eletrônica de transmissão do vírus de Influenza. FONTE: adaptado de Goldsby et al. (2000).

Data de 412 a.C. os primeiros registros de sua ocorrência que se tem conhecimento. Há relatos de epidemias em seres humanos ocorridas na Europa em 1414, 1557, 1675-1676, 1788 1790 e em 1830-1832. (Smith, 1995). No século XX, quatro pandemias acometeram o mundo em 1918, 1957, 1968 e 1977, sendo a de 1918 - denominada de gripe espanhola (H1N1) considerada a pandemia mais grave que se tem notícia, matando mais de 40 milhões de pessoas em todo o planeta (Taubenberger et al., 2001).

Em 1933 o vírus foi identificado por Wilson Smith, Cristopher Andrewes e Patrick Laidlow do National Institute for Medical Reseach em Londres após uma epidemia. Atualmente 
este vírus é classificado como sendo do tipo A. Em 1940 e 1950, respectivamente foram descobertas a existência de um tipo B e C do vírus da Influenza (Hilleman, 2002). Dos tipos virais descritos, somente o tipo A pode acometer o homem e animais silvestres e domésticos. Os tipos B e C atacam somente o ser humano sendo o primeiro capaz de promover epidemias e o segundo apenas sintomas subclínicos.

Em 1957 um novo vírus da influenza apareceu no sudeste da China. Tratava-se de uma influenza do tipo A e subtipo H2N2 causando uma nova pandemia denominada "gripe asiática". Neste período as cepas de H1N1 desapareceram completamente da população humana. No ano de 1968 uma nova pandemia apareceu na China, a chamada "gripe de Hong Kong”. O vírus responsável era do subtipo H3N2 (Cox e Subbarao, 2000).

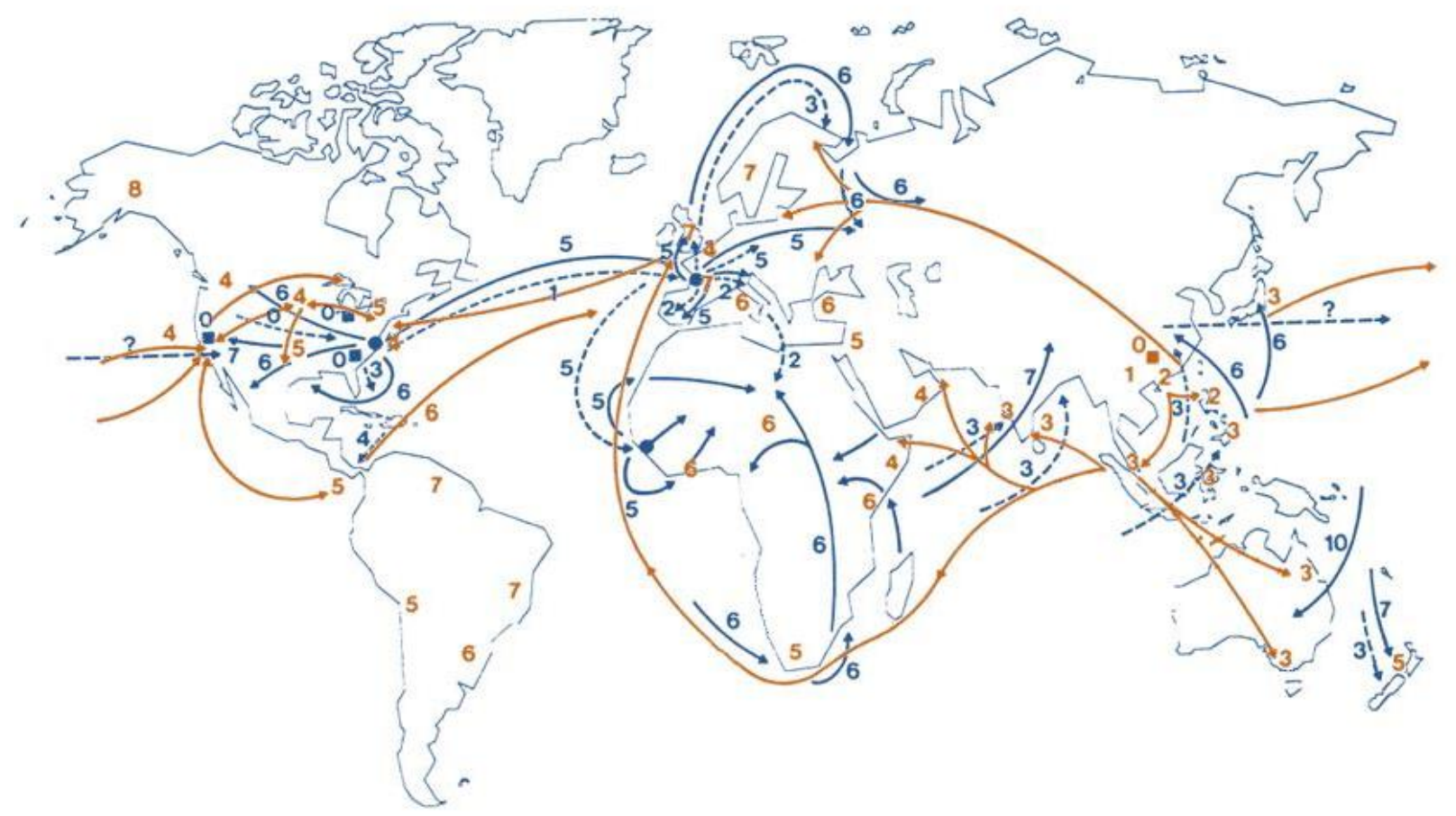

Figura 2- Mapa demonstrando a pandemia de influenza em 1918. Primeiras manifestações ( $\square$ ) Março de 1918; linhas de propagação da primeira onda de infestação $\left(M^{\prime}\right.$ ), linhas de propagação da segunda onda de infestação $(\longrightarrow)$; pontos focais da segunda onda de infestação $(\bullet)$ : Pandemia de 1957 (setas vermelhas), ponto de origem em fevereiro de 1957 ( $\square$ ) linhas de propagação da onda de infestação $(\rightarrow)$ ).

FONTE : adaptado de Potter (2001). 1 
A pandemia de 1977, denominada gripe Russa, foi marcada pelo reaparecimento do Subtipo H1N1 e o desaparecimento das cepas de H3N2 das populações humanas. Esta pandemia foi caracterizada pela capacidade do vírus da Influenza em infectar principalmente crianças e jovens, sendo as pessoas de mais de 50 anos pouco afetadas. Mais de 50\% das crianças em idade escolar em todo o mundo foram infectadas, porém com baixas taxas de mortalidade (Laver e Garman, 2002; Cox e Subbarao, 2000).

Todos os vírus da influenza conhecidos pertencem à família Orthomyxoviridae,sendo que este táxon abriga 5 gêneros diferentes, 3 de influenza (Influenzavirus A, Influenzavirus $B$ e Influenzavirus $C$ ) além dos Thogotovirus (transmitidos por carrapatos ao homem não causando os sintomas de influenza) e Isavirus (responsáveis pela anemia infecciosa em salmão, sendo transmissão feita de peixe para peixe pela água). O vírus da influenza A, B e o Vírus causador da anemia infecciosa em salmões tem seu genoma composto por 8 segmentos de RNA de polaridade negativa (complementar ao RNA mensageiro). Os vírus da Influenza C e o Dhori Vírus (um Thogotovirus) tem 7 segmentos enquanto o vírus Thogoto tem 6 segmentos de RNA (Büchem e Osmond, 2003; Calisher, 2009).

Cada segmento do RNAv está associado à nucleoproteína NP (Klumpp et al., 1997) e a um complexo de polimerase viral (Brown, 2000).

Os segmentos 1, 2 e 3 codificam respectivamente as proteínas PB2 (com função de transcriptase de ligação a qual inicia o processo de transcrição), PB1 (transcriptase com função de alongamento, responsável pelo processo de elongação RNA mensageiro viral) e PA, uma protease de atividade ainda incerta, mas que é necessária para a transcrição e replicação do RNAv. (Hay, 1998; Calisher, 2009.).

A hemaglutinina (HA) é codificada pelo segmento 4 sendo a glicoproteína de superfície viral mais imunogênica. Essa proteína permite o vírus ter acesso ao citoplasma celular. A HA se liga ao receptor de ácido siálico existente na superfície celular e age na fusão da partícula viral com a membrana endossomica permitindo o acesso viral ao citoplasma celular (Skehel e Wiley, 2002; Webster, 1992).

O segmento 5 é o codificador da nucleoproteína NP a qual tem a função no núcleo da célula hospedeira de encapsidar o RNA viral tornando-o estável e protegendo-o da ação de RNAses (ribonucleases) (Mena et al., 1999).

No segmento 6 é codificada a neuraminidase (NA) que através da degradação do ácido 
siálico do muco extracelular, auxilia na dispersão do vírus através da destruição dos receptores de HA da superfície celular.

As proteínas M1, que faz parte da matriz protéica formando uma camada elétron-densa logo abaixo do envelope viral, e M2 - que tem a função de formar os canais iônicos os quais permitem a acidificação do interior dos vírions favorecendo o desempacotamento viral - são codificadas pelo segmento 7. O segmento 8 codifica as proteínas não estruturais NS1 com função de transporte, tradução e entrelaçamento do RNAv e NS2 ainda de função desconhecida (Calisher, 2009).

Este genoma está envolvido em uma matriz protéica constituída por proteína M1, a qual está envolta por uma bicamada lipídica derivada da célula hospedeira (Braakman e Anken, 2000). Projetam-se através da bicamada lipídica do envelope viral duas glicoproteínas de superfície, codificadas pelo genoma do vírus, denominadas HA e a NA. Ainda, uma terceira proteína, formadora de canais (M2), encontra-se inserida na bicamada lipídica (Mould et al., 2000).

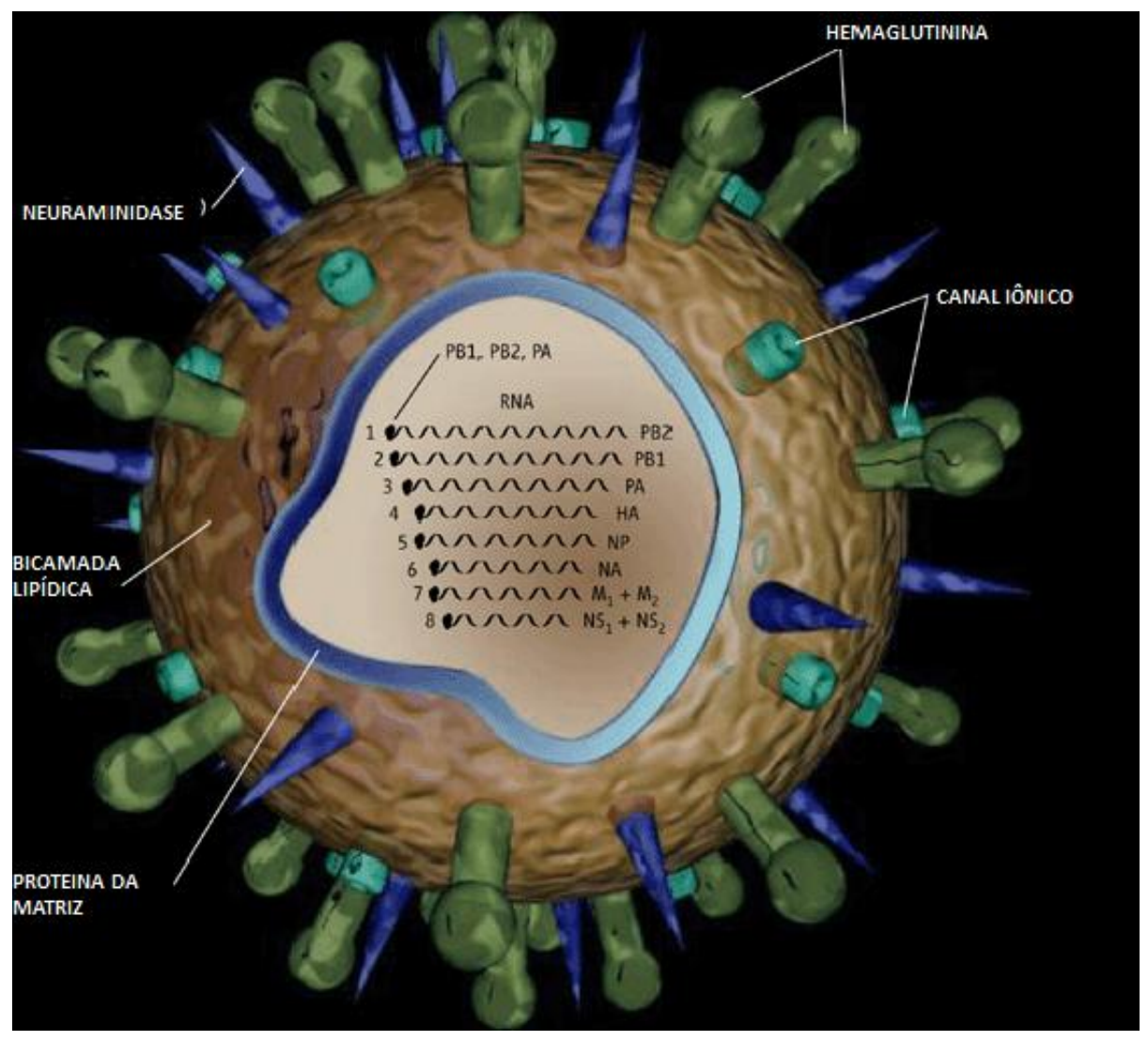

Figura 3 - Modelo estrutural do vírus da influenza do tipo A. FONTE: adaptado de Kaiser (2006). 
O vírus do tipo A pode ser subdividido em outros subtipos com diferenças nas propriedades antigênicas de suas duas glicoproteínas de superfície denominadas hemaglutinina (HA) e neuraminidase (NA). Por alguns anos foram classificados 15 subtipos de hemaglutininas e nove subtipos de neuraminidases (Laver, 2002). Um décimo sexto subtipo de hemaglutinina foi recentemente descoberto em amostras de gaivota-de-cabeça-negra (Larus ridibundus) no norte da Europa (Fouchier et al., 2005).

Dois mecanismos principais são responsáveis pela mudança contínua na antigenicidade dos vírus da influenza, e são denominados "shift" antigênico e "drift" antigênico (Zambon, 1999).

O "drift" resulta do acumulo de mutações que alteram o tipo de aminoácidos que compõe as proteínas, ocorrendo tanto na hemaglutinina como na neuraminidase, resultando na alteração gradual do vírus. Estas alterações vão reduzir a ligação dos anticorpos do organismo infectado e diminuir assim a imunidade que já poderia existir devido ao contato deste organismo com outros vírus da influenza, facilitando a disseminação do vírus com as modificações. Dependendo do tipo de modificação estabelecida pode ocorrer imunidade parcial. (Nakajima et al., 2000).

O "shift" pode ser definido como o aparecimento de um vírus da influenza A contendo um novo subtipo de HA ou de HA e NA, resultado da alteração drástica destas proteínas, uma vez que todo um segmento genético viral é substituído por outro segmento que codifica a mesma proteína. Este processo pode ocorrer quando duas estirpes virais de diferentes origens infectam a mesma célula hospedeira. Durante o encapsulamento do material genético pode haver rearranjos levando ao surgimento de um vírus contendo segmentos genéticos de duas estirpes diferentes (Cox e Subbarao, 2000).

A maioria da população não apresenta imunidade para estas novas estirpes podendo surgir assim novas pandemias. Além dos mecanismos de "shift" e "drift", o ressurgimento de uma estirpe antiga do vírus pode causar por si só um novo surto. Recentemente descobriu-se que pode acontecer outro tipo de "shift" antigênico, quando um tipo de Influenza animal consegue transpor a barreira da espécie (Cox e Subbarao, 2000).

Através da HA as partículas virais ligam-se a receptores de ácido siálico localizados superfície celular e assim ocorre a endocitose do vírion. Esse é então liberado no citoplasma da célula hospedeira. Após a entrada viral, os nucleocapsídeos migram para o núcleo da célula e, as 
proteínas com atividade de polimerase iniciam a transcrição das partículas de RNA do vírion (RNAv) em RNA mensageiro (RNAm) (Yewdell e García-Sastre, 2002). Compõem o complexo de transcriptase viral, as proteínas PB1, PB2 e PA. A polimerase PB2 inicia o processo de transcrição. A PB1 é responsável pelo processo de elongação do RNAm viral. A função da polimerase PA na transcrição primária ainda não é conhecida, no entanto este polipeptídio é necessário para a transcrição e replicação do RNAv (Nakagawa et al., 1996).

Os transcritos produzidos são utilizados na tradução das proteínas virais. Acredita-se que o aumento da concentração de NP livre dispare a mudança da síntese de RNAm (transcrição) para a síntese de RNAc (RNA complementar) e RNAv (replicação). A replicação do RNAv começa com a mudança de síntese de RNAm para RNAc e culmina com a síntese do RNAv genômico que utiliza moléculas de RNAc como molde (Honda et al., 2001).

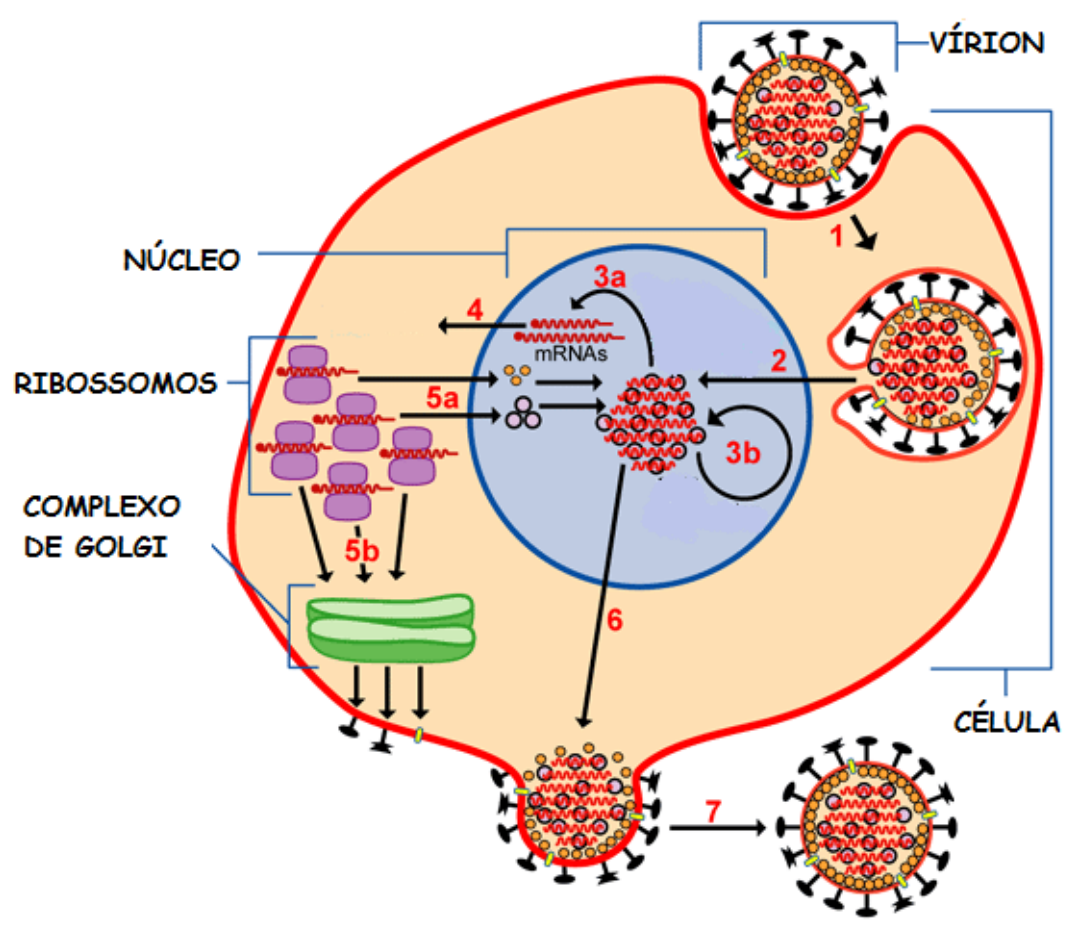

Figura 4 - Ciclo de vida do vírus da Influenza.Passo 1- formação do endossomo. Passo 2 - migração dos nucleocapsídeos ao núcleo da célula. Passo 3a - transcrição realizada pelo complexo de polimerase viral. Passo 3b - replicação do RNAv. Passo 4- migração do RNAm para o citoplasma. Passo 5a - migração das proteínas NP,NS1 e M1 sintetizadas nos ribossomos para o núcleo celular Passo 5 b - Transporte da NA,HA e proteína M via Complexo de Golgi para a membrana celular. Passo 6 - migração dos nucleocapsídeos formados no núcleo celular para a membrana na região de fixação das HA, NA e M. Passo 7 --Saída dos novos vírions.

FONTE: Modificada de NCBI([2010]). 
Pouco se sabe a respeito do processo de montagem dos vírus da influenza. Acredita-se que nucleocapsídeos envolvidos por uma cápsula de proteína M1 migrem para a face interna da membrana plasmática, para onde já foram transportadas as glicoproteínas HA, NA e M2. Foi proposto que a interação de M1 com os domínios citoplasmáticos dessas 3 glicoproteínas sinalize o processo de brotamento (Hilleman, 2002).

A detecção do vírus da influenza pode ser realizada através de várias metodologias. O método laboratorial padrão para o diagnóstico de Influenza é baseado no isolamento do vírus em cultura de células (Harmon, 1992). Este método, seguido da detecção dos antígenos virais utilizando anticorpos específicos, é uma metodologia sensível e específica, mas requer infraestrutura e pessoal especializado, sendo também uma técnica demorada [cerca de 10 dias] (Murphy e Webster, 2001). Porém, outros métodos de detecção dos antígenos virais, diretamente das amostras clínicas podem ser utilizados ensaios de imunofluorescência (IFA) e imunoenzimático (ELISA) (Reina et al., 1996) e reação de hemaglutinação (Herrmann et al.,2001). Esta última permite a detecção e tipagem utilizando anticorpos específicos contra HA e NA, (Wright et al., 1995).

A reação em cadeia pela polimerase (PCR) é um método alternativo, que permite a detecção do ácido nucléico viral, sendo mais rápido e sensível, que o método padrão (Cherian et al., 1994). A utilização da reação em cadeia pela polimerase após a transcrição reversa (RT-PCR) é descrita por vários autores para detecção, tipagem e subtipagem dos vírus Influenza (Besselaar et al., 2004; Herrmann et al., 2001; Stockton et al., 1998; Ellis et al., 1997). A multiplex PCR, com primers (oigonucleotídeo iniciador) específicos para os genes da $\mathrm{H}$ e/ou $\mathrm{N}$, é utilizada na detecção dos Influenzavirus A, B, C e na subtipagem do Influenzavirus A (Besselaar et al., 2004; Pontoriero et al., 2003; Poddar et al., 2002; Choi et al., 2002; Ellis et al., 1997). Já o Real-Time PCR gerou uma maior aceitação que a PCR, por ser um método que apresenta maior rapidez, sensibilidade, reprodutibilidade e redução do risco de contaminação durante o processo (Mackay et al., 2002; Van der Vries et al., 2010).

Estudos ecológicos do vírus de influenza conduziram a hipótese que todas os que acometem mamíferos derivam de reservatórios destes vírus nas aves. O suporte desta teoria vem das análises filogenéticas das sequiências de ácidos nucléicos da influenza A. Análises do gene da nucleoproteina (NP) demonstram que os vírus da influenza aviária estão em cinco linhagens hospedeiros-específicas: eqüina antiga, que não foi isolado nos últimos 15 anos; equina recente; 
gaivota; suína; e do ser humano. Os vírus humanos e os clássicos suínos, são considerados geneticamente grupos irmãos, demonstrando que tem uma origem comum. $\mathrm{O}$ antepassado do vírus humano e dos suínos parece ter sido um vírus aviário parecido com o vírus de influenza que circulou em porcos domésticos na Europa. Esse possui todos seus genes idênticos aos das fontes aviárias (Gorman et al., 1990; Garmelin et al., 1990).

Até mesmo a pandemia mais devastadora que se tem notícia, a gripe espanhola em 1918, teve sua origem no vírus aviário do tipo A subtipo H1N1 (Taubenberger et al., 2001).

A influenza aviária, também chamada de peste aviária, foi descrita no ano de 1878 pelo pesquisador italiano Perroncito, que a diferenciou das doenças causadas por bactérias. Em 1901 foi identificada sendo causada por um agente filtrável (vírus) por Centanni e Savunozzi. Nos Estados Unidos, a doença foi diagnosticada em Nova York infectando frangos de corte em 1924, disseminando-se por vários estados norte americanos. Outro surto ocorreu em Nova Jersey, no ano de 1929. Mas, foi apenas em 1955, que a chamada peste aviária foi identificada como sendo causada por um vírus da influenza, que atualmente é descrito com sendo do tipo A. Nos anos seguintes, vários surtos da doença com amostras de alta patogenicidade do vírus foram descritos em muitos lugares do mundo, entre eles a América do Sul e do Norte, Norte da África, Oriente Médio e Europa, incluindo a Inglaterra e o leste europeu (Berchieri Jr e Macari, 2000).

Os pools genéticos de todos os vírus de influenza aviária aparecem primariamente nas aves aquáticas, que são responsáveis pela perpetuação deste vírus na natureza. (Alexander, 2000).

$\mathrm{O}$ vírus da gripe, normalmente não provoca doença ou sintomas em aves aquáticas, consideradas como reservatórios dos 16 subtipos de hemaglutininas (HA) e 9 subtipos de neuraminidase (NA). Sua replicação é preferencialmente realizada em células do trato gastrointestinal (Webster et al., 1992).

As aves aquáticas, em sua maioria, costumam se agrupar em dormitórios e áreas de nidificação, onde há a deposição de grandes quantidades de fezes. Vírus de influenza aviária tem sido isolado do material fresco de fezes colhidas nestas localidades, bem como na água dos lagos, o que indica um eficiente método de transmissão da influenza. A não virulenta natureza da infecção do vírus da influenza em aves aquáticas pode ser resultado de uma adaptação que vem ocorrendo há séculos do vírus ao hospedeiro, criando-se assim um reservatório para a perpetuação do vírus (Webster, 1998).

O vírus da influenza de origem aviária tem sido encontrado em várias infestações de 
influenza em mamíferos marinhos (como nas baleias e focas), em porcos, cavalos, cachorros e em outras espécies de aves silvestres e domesticas, como no caso das criações de frango (Geraci et al., 1982; Hinshaw et al., 1986; Scholitssek et al., 1983; Horimoto et al., 1995; Capua e Alexander, 2002).

Dois grupos (de acordo com sua habilidade de provocar doença e a gravidade dos sintomas que causam) podem ser reconhecidos para o vírus de influenza do tipo A. O primeiro denominado vírus da influenza altamente patogênicos para aves (HPAI, sigla em inglês para highly pathogenenic avian influenza) pode exterminar uma criação de aves domésticas. Estes vírus estão restritos aos subtipos H5 e H7. Todos os outros subtipos conhecidos causam apenas sintomas brandos, em sua maioria atacam o sistema respiratório e são designados como vírus pouco patogênicos para aves (LPAI, sigla em inglês para low pathogenic avian influenza). O vírus da HPAI tem sido combatido nas populações de aves domésticas em todo o mundo, porém pode ser novamente reintroduzido por contato das criações com aves domésticas importadas ou ainda aves de estimação ou silvestres. (The Center for Food Segurity \& Public Health, 2010).

Apesar das infecções virais do tipo LPAI serem brandas, não podem ser ignoradas do ponto de vista comercial, pois, provocam expressiva queda na produção de ovos no período em que as aves poedeiras ficarem debilitadas (Alexander, 2000). Entre 1959 a 2004 foram registrados 24 eventos de HPAI em todo o mundo com milhões de aves domésticas indo a óbito ou sacrificadas, acarretando prejuízos de bilhões de dólares (Capua e Alexander, 2004).

Após o surgimento de um subtipo que ainda não havia infectado seres humanos ou aves, mamíferos marinhos e mamíferos domésticos suscetíveis, ocorrem normalmente epidemias devido à rápida expansão deste vírus através das populações de aves (Bridges et al., 2003). Depois de estabelecido nestas populações, um subtipo do vírus da influenza precisa alterar as propriedades antigênicas de suas duas glicoproteínas de superfície (hemaglutinina e a neuraminidase), para que possa escapar do sistema imune do hospedeiro e assim, continue a gerar novos surtos ou epidemias.

Uma das formas naturais de disseminação do vírus da influenza pelo globo poderia estar ligada então ao carreamento destas estirpes do vírus da Influenza tipo A por intermédio de aves migratórias, principalmente as aquáticas, em que várias espécies não adoecem quando em contato com o vírus, servindo apenas como reservatório (Capua e Alexander, 2002). 


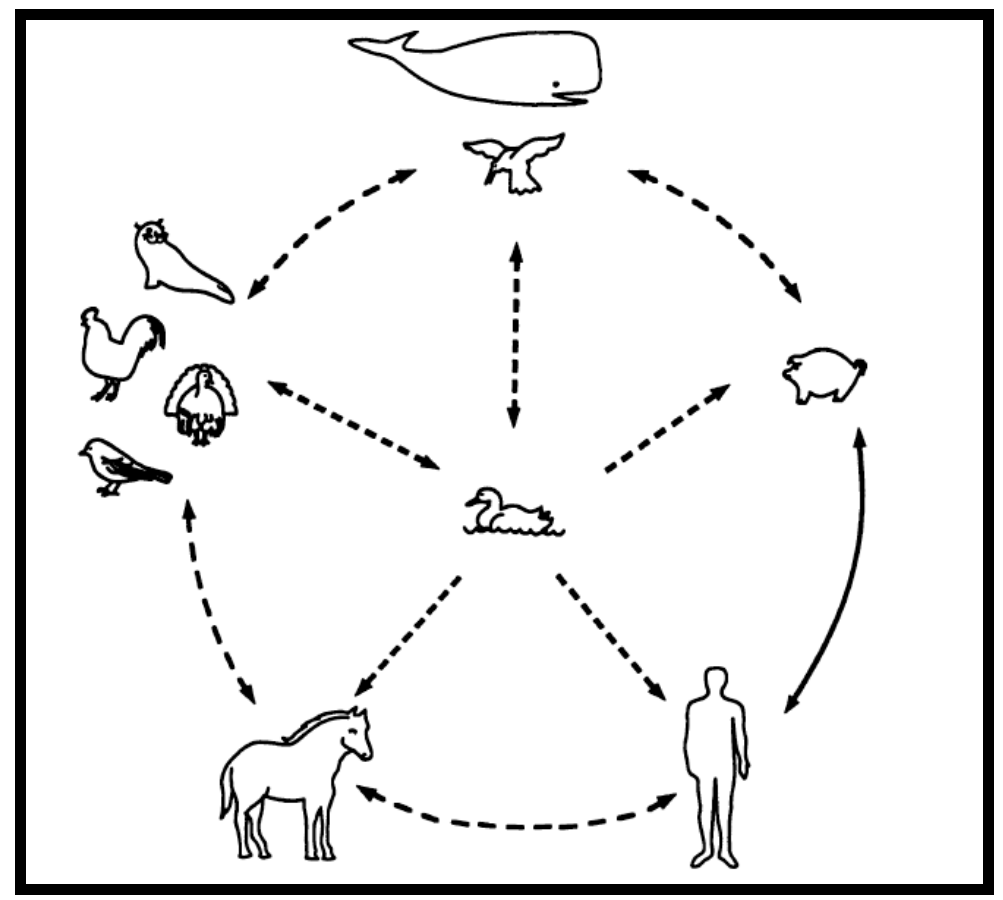

Figura 5 - Reservatórios do vírus de influenza A. As aves aquáticas são os reservatórios primordiais de todas as viroses que acometem várias espécies de mamíferos e aves.

FONTE: modificada de Webster (1992).

O tamanho considerável da população mundial de aves silvestres, a ausência de fronteiras, a liberdade de movimentos das aves migratórias, os vários pontos de encontro para reprodução, alimentação ou descanso entre várias espécies, a rapidez com que estes movimentos são realizados em alguns casos e o contato com o homem em situações de campo ou urbanas, fazem com que esse grupo seja considerado extremamente importante de disseminação viral. Ainda não é conhecida qual a suscetibilidade de cada uma dessas espécies migrantes de se tornar um potencial reservatório, condutor e transmissor do vírus. Para que isso fosse possível seria necessário um maior conhecimento sobre a epidemiologia do vírus da influenza em diferentes grupos de aves, informações sobre a ecologia e comportamento, além dos padrões migratórios das espécies (Soares et al., 2005).

Algumas rotas migratórias aviárias são bem conhecidas e foram agrupadas e denominadas como flyways (Figura 2) para facilitar os esforços internacionais de manejo e conservação. A definição de uma flyway pode ser descrita como "a completa extensão na qual uma espécie migratória aviária (ou grupos, ou espécies relacionadas, ou populações distintas de 
uma mesma espécie) se locomove anualmente de uma área de reprodução para uma área de nãoreprodução, incluindo lugares intermediários de descanso e alimentação, bem como áreas de ocorrência das mesmas" (Boere e Stroud, 2006).

O monitoramento, outro ponto importante, facilitaria na obtenção de dados dos subtipos prevalentes nas populações aviárias, suas características patogênicas e antigênicas. Além disso, é essencial para a identificação de subtipos com capacidade de gerar epidemias ou até mesmo uma pandemia (Soares et al., 2005). Por intermédio do monitoramento torna-se possível formar painéis de cepas de referência que poderão ser utilizadas na fabricação de vacinas para eventuais epidemias ou pandemia causadas na população por vírus de origem aviária.

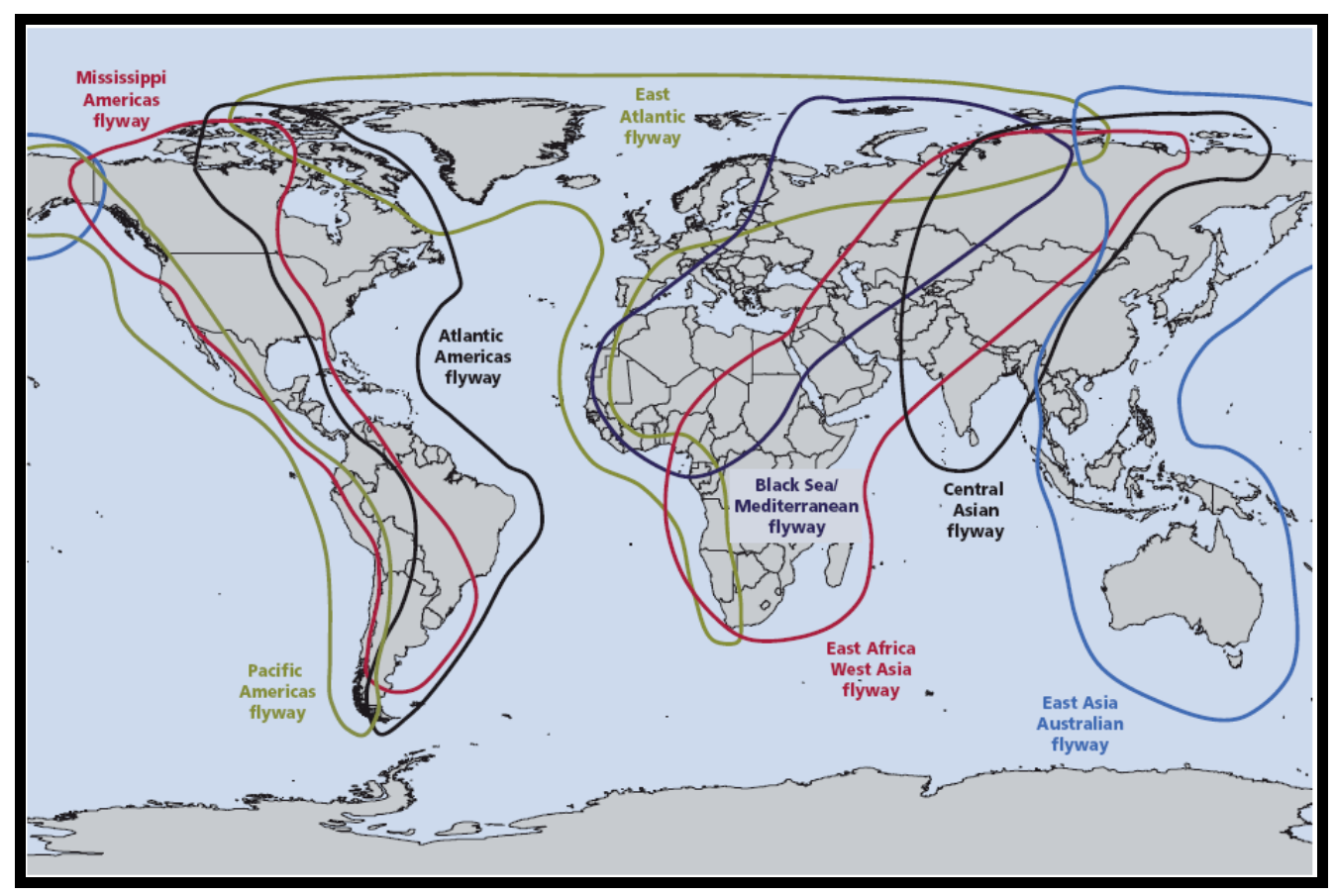

Figura 6 - Principais rotas migratórias (“flyways”) de aves que se deslocam entre as áreas de reprodução no verão e as áreas de invernada, ligando os hemisférios norte e sul. FONTE : Boere e Stroud (2006).

O monitoramento das aves silvestres deve incluir as espécies migratórias, que em sua rota passam por vários países do mundo e assim, podem transportar vírus da influenza infectando populações de aves residentes e vice-versa. Apesar de 105 espécies de aves pertencentes a 15 famílias diferentes serem comprovadamente portadoras de vírus da influenza ou suscetíveis a infecções causadas pelo vírus, apresentando sintomas ou não, a maior variedade de subtipos e a maioria dos isolados foram obtidos dos Anseriformes, como patos, marrecos, gansos e afins 
(Alexander, 2000; Olsen et al., 2006).

O vírus da influenza tem sido isolado em aves de todos os continentes, com exceção da Antártica. Até o momento existem quatro estudos que sugerem a presença deste vírus na avifauna antártica, porém esses estudos referem-se apenas a dados sorológicos (Wallensten et al., 2006b)

A Antártica é um dos menores continentes em superfície (14 milhões de quilômetros quadrados) e o mais meridional deles. Está posicionado no Pólo Sul e encontra-se quase que completamente recoberto por enormes geleiras (glaciares). Foi formado na separação do antigo continente Gondwana há aproximadamente 65 milhões de anos e seu resfriamento ocorreu nos últimos quarenta milhões de anos. Todas as adaptações da fauna antártica existente ocorreram então nesses últimos quarenta milhões de anos (Hunford, 2002).

A avifauna antártica é composta por 35 espécies de diferentes aves marinhas aquáticas das quais 19 se reproduzem no próprio continente. $\mathrm{O}$ restante se reproduz em ilhas oceânicas, todas pertencentes à região sub antártica. Estima-se que mais de 100 milhões de aves aquáticas marinhas vivem na costa da Antártica e ilhas adjacentes.

Os pinguins estão representados por 17 espécies no mundo, das quais 4 tem seus sítios de reprodução no próprio continente antártico, o pinguim - papua (Pygoscelis papua), o pinguim antartico (Pygoscelis antartica), o pinguim - adélia (Pygoscelis adeliae) e o pinguim imperador (Aptenodytes forsteri) Todas as outras espécies antarticas tem sua área de vida circunscrita na região subantartica (Williams, 1995). 


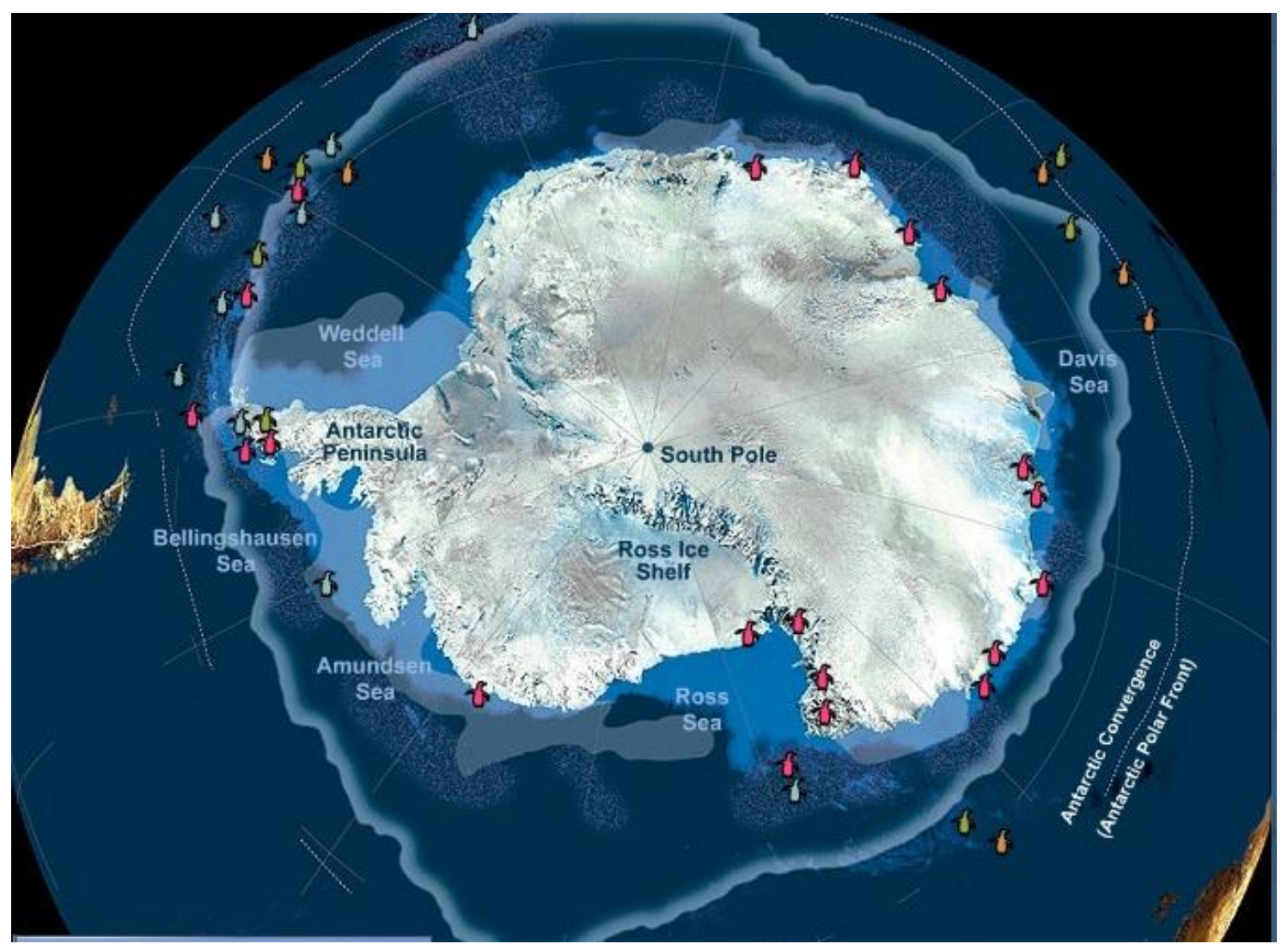

Figura 7 - Distribuição das espécies de pinguins no continente antártico Em rosa pinguim - adélia, em azul pinguim - antártico, em verde pinguim - papua e em laranja pinguim -rei. FONTE: National Geographic Society ([2010]).

A chegada do ser humano no continente antártico foi bastante recente. Há relatos do reconhecimento da Antártica pela tribo Aush da Terra do Fogo que em suas crenças sempre citavam o "país de gelo". O chefe Maori (tribo que conquistou a atual Nova Zelândia) Ui-TeRangiora teria atingido a região em 650 d.C. A passagem destas duas tribos aparenta ser somente sazonal e circunscrita as ilhas ao redor, pois até o momento nenhum vestígio significativo de sua permanência foi encontrado.

A ocupação humana definitiva começa na primeira metade do século XIX, quando navios baleeiros chegavam à região das Ilhas Sandwich do Sul. Foi ainda nesse período que James Weddell e James Clark Ross descobriram os mares que hoje levam seus nomes (Izaguirre, 2000).

Nos últimos tempos o contato de seres humanos com os animais antárticos vem aumentando, não só devido às bases de pesquisas instaladas por quase todo continente, mas 
também pelo aumento desenfreado do turismo, trazendo um número cada vez maior de pessoas de diversas localidades do mundo.

Desta forma, devido o número muito grande de aves aquáticas marinhas, bem como ao crescente avanço da população humana no continente antártico, o monitoramento do vírus da influenza nas populações das aves antárticas deve ser cada vez mais intensificado, como forma de se entender a dinâmica envolvida nos processos epidemiológicos desse vírus. 


\section{JUSTIFICATIVA E RELEVÂNCIA}

A recente ocupação do continente antártico pelo homem causa preocupação, não só pelas interferências provocadas neste frágil ambiente de baixas temperaturas, mas também pelo desconhecimento de quais são os possíveis consequências que esta nova frente de ocupação causará à própria população humana.

Estima-se que vivam no continente antártico e ilhas periféricas mais de 100 milhões de aves aquáticas marinhas. Seus hábitos de nidificação são geralmente grupais sendo que alguns ninhais podem passar de dezenas de milhares de indivíduos. Este tipo de situação, devido à aglomeração de aves e o inevitável contato com o guano que se acumula nos ninhais, propiciariam em qualquer outro local do mundo condições quase que perfeitas para a disseminação do vírus da influenza.

Até o momento, indícios da presença deste vírus na Antártica foram obtidos através de dados sorológicos de material coletado de pinguins (Wallensten et al., 2006b). A dificuldade de acesso ao continente, o deslocamento sempre muito complicado em terra, as condições inóspitas a vida humana, o específico manejo dos animais para coleta das amostras e o demorado transporte dos materiais coletados, podem estar contribuindo de forma decisiva ao não isolamento deste vírus nas populações de aves antárticas.

Alguns pesquisadores acreditam que a presença do vírus da influenza nas aves e mamíferos aquáticos na Antártica pode estar mais ligada ao carreamento deste patógeno pela migração realizada por algumas espécies de aves às zonas temperadas do planeta (Morgan, 1981; Wallensten et al., 2006a; Morgan, 1988) do que propriamente pelo contato humano.

Ocorre que, nos últimos tempos, o continente antártico tem sido cada vez mais ocupado pelo ser humano, com a instalação de bases de pesquisas e refúgios e pelo aumento desenfreado do turismo, trazendo um número cada vez maior de pessoas de diversas localidades do mundo. Este fato pode estar mudando de forma decisiva a relação de transmissão do vírus circulante, bem como os tipos de variantes envolvidas.

A necessidade de estudos que possam mapear as cepas virais que estão circulantes no ecossistema Antártico faz-se então necessário, já que o pouco conhecimento destas traz incertezas sobre a possibilidade de transmissão das cepas comuns ao ser humano para os organismos antárticos, bem como a possibilidade de variantes desconhecidas para as populações humanas que 
estiveram restritas a este ambiente passem as ser carreadas e a circular por outras localidades do mundo. 


\section{OBJETIVOS}

1. Detectar o vírus da influenza do tipo A através da RT - PCR em pinguins residentes da região Antártica.

2. Testar diferentes técnicas moleculares para a validação dos resultados positivos encontrados através da RT- PCR utilizada na detecção dos vírus da influenza tipo A em material oral e cloacal colhido de pinguins da região Antártica

3. Determinar os subtipos de influenza A nas amostras positivas para o conhecimento do pool viral existente nestas aves e comparar suas semelhanças aos pools circulantes em outras populações de animais e humanas. 


\section{MATERIAL E METODOS}

\subsection{Expedição para coleta de amostras}

Foram realizadas três expedições à região Antártica nas estações de verão do ano 20062007, 2007-2008 e 2008-2009 com a finalidade de coletar amostras. A chegada ao local, bem como a estrutura para coleta e manutenção na área de estudo, foi provida pelo Programa Antártico Brasileiro.

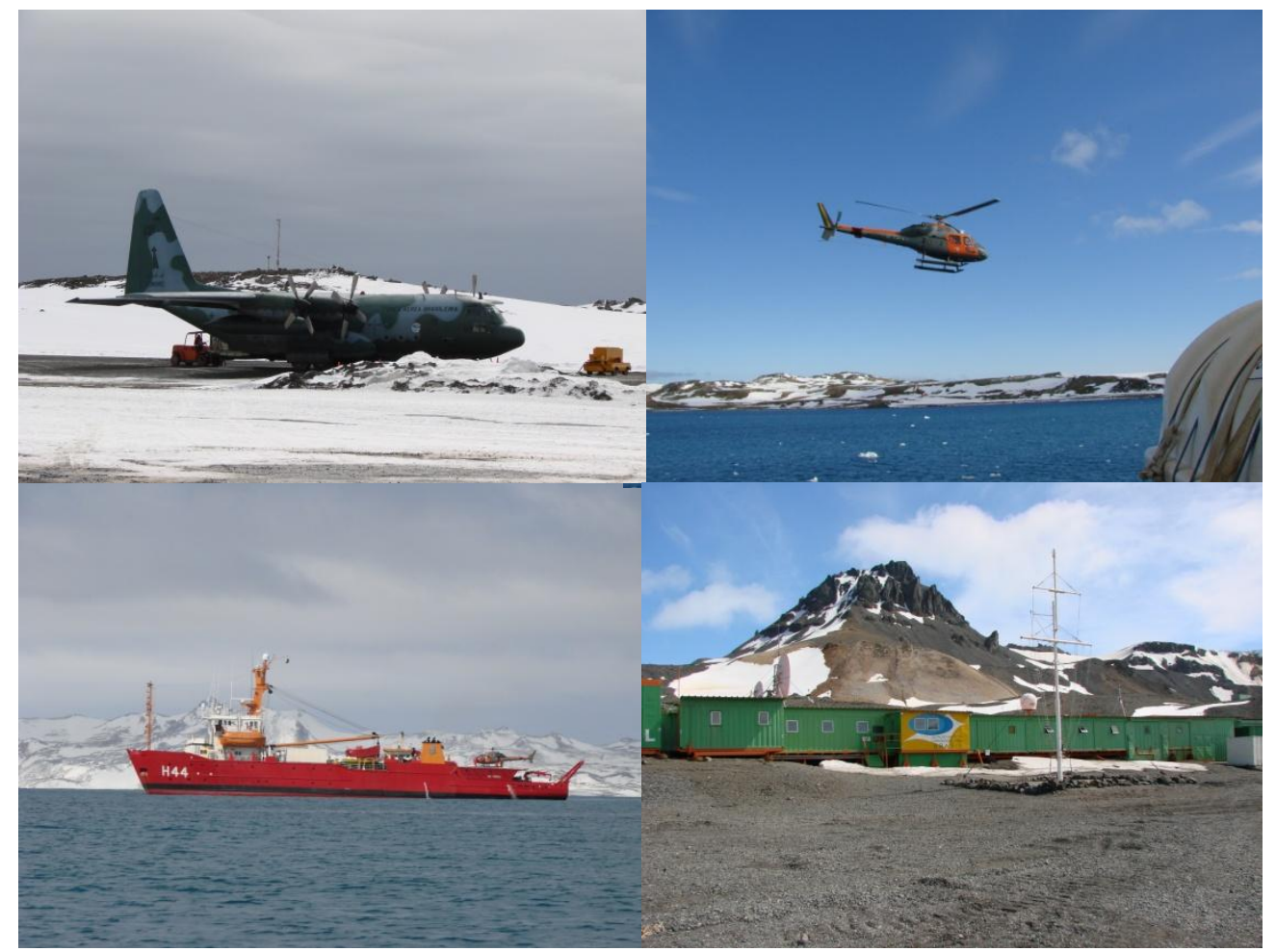

Figura 8 - Estrutura colocada a disposição pelo Programa Antártico Brasileiro utilizada para a realização do trabalho.

Durante as três estações de verão antártico foram realizadas coletas de material de 283 pinguins de quatro espécies diferentes. As amostras cloacais e orais foram colhidas em duplicata, uma em Trizol e outra em meio mínimo essencial Eagle (MEM), sendo o soro e o hematócrito remanescente coletado somente em uma única amostra por ave, perfazendo um total de 1132 amostras. 
No ano de 2006 a coleta de amostras foi toda concentrada na península Keller, local onde se encontra sediada a Base Antártica Brasileira Comandante Ferraz (62 $\left.08^{\circ} \mathrm{S}, 58^{\circ} 25^{\prime} \mathrm{W}\right)$ que se localiza na Baía do Almirantado, na ponta da grande península Antártica. A Ilha Rei George é a maior da região, distante $120 \mathrm{~km}$ da costa da Antártica e $900 \mathrm{~km}$ do continente Americano. O período de coleta para essa expedição foi de 20 de novembro a 6 de dezembro.

A área costeira da ilha é habitada por focas-de-weddell, lobos e lobos-marinhos, e diversas espécies de aves incluindo pinguins. A ocupação humana da Ilha Rei George limita-se às estações de pesquisa pertencentes à Argentina, Brasil, Chile, China, Coréia do Sul, Peru, Polônia, Rússia e Uruguai. A maioria das estações é permanente e realizam pesquisas principalmente nas áreas de biologia, ecologia, geologia e paleontologia (Scar, 2008).

As amostras dos pinguins manejados no ano de 2006 foram colhidas nas proximidades do Módulo de Química (container laboratório situado a aproximadamente a $800 \mathrm{~m}$ da Estação Antártica Comandante Ferraz), na Punta Plaza (localidade ao sul da EACF), na Punta Hennequin (localidade ao norte da EACF) e no Refúgio 1 (container abrigo localizado ao sul da EACF) ou durante o deslocamento da equipe entre as localidades citadas.

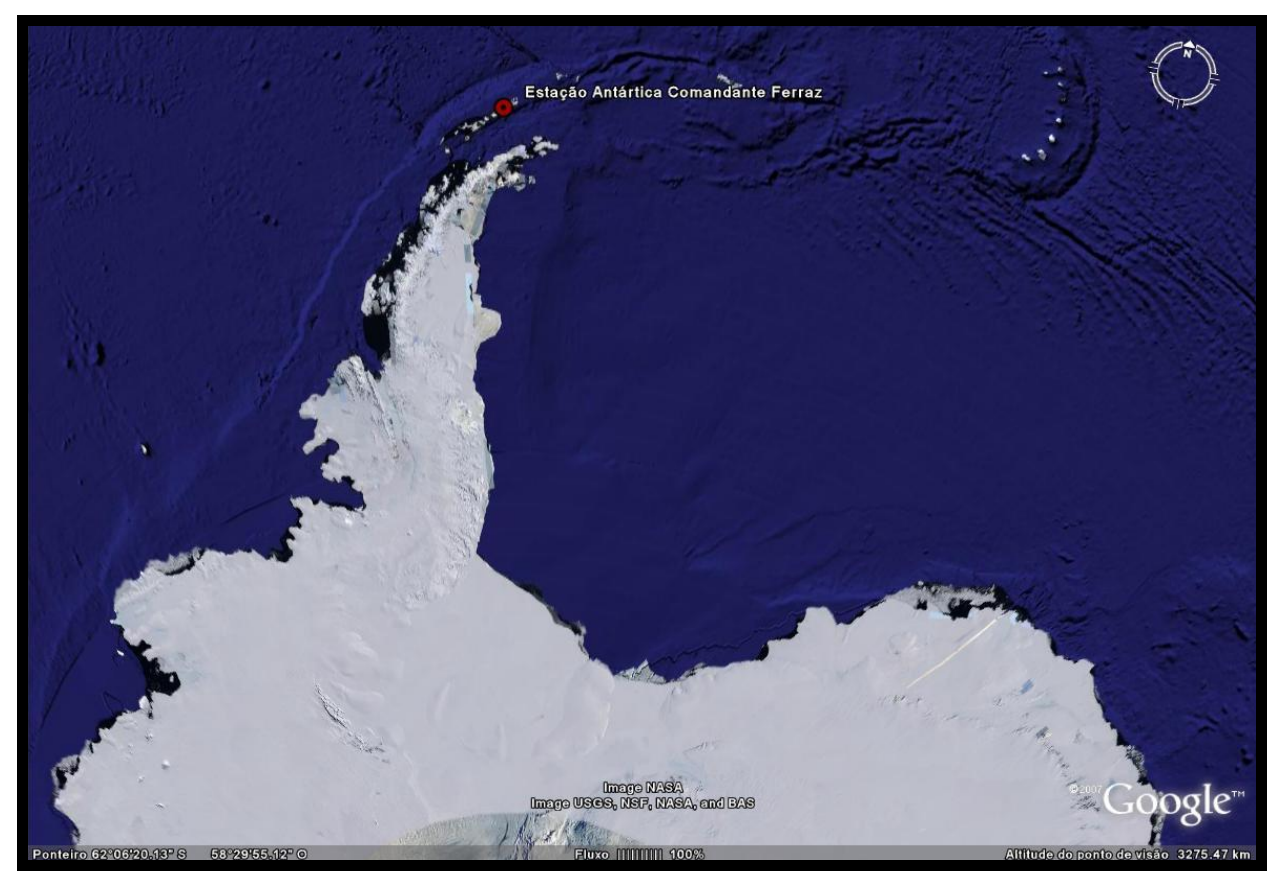

Figura 9 - Imagem de satélite mostrando a localização da Estação Brasileira Comandante Ferraz, na Ilha Rei George, ponta da grande Península Ántártica.

FONTE: Programa GoogleEarthTM ([2010]). 


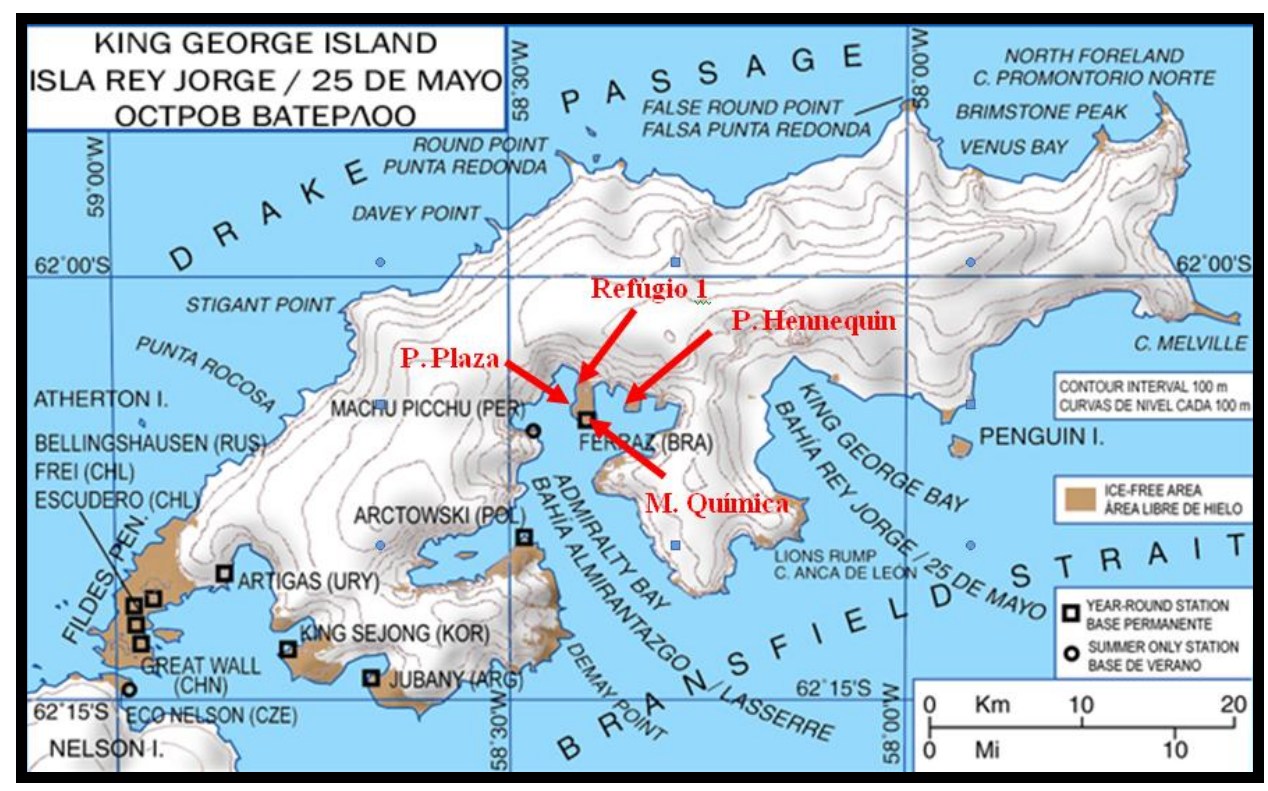

Figura 10 - Mapa da Ilha Rei George mostrando a localização da Estação Brasileira Comandante Ferraz e os pontos de coleta de material em Punta Plaza, Punta Heinnequin, Refúgio 1 e o Módulo de Química.

FONTE: modificado de Wikipedia ([2010]).

A Ilha elefante $\left(61^{\circ} 08^{\prime} \mathrm{S}, 55^{\circ} 07^{\prime} \mathrm{W}\right)$, que faz parte do território Britânico da Antártica, é uma ilha montanhosa e coberta de gelo localizada ao largo da costa da Antártica e pertencente ao arquipélago das Ilhas Shetland do Sul, no Oceano Antártico. Situa-se a 1.209 km a oeste-sudoeste das Ilhas Geórgia do Sul e Sandwich do Sul, 940 km das Ilhas Malvinas e 890 km a sudeste do Cabo Horn. Neste local foram coletadas as amostra no verão de 2007/2008 no período de 04 de dezembro a 21 de dezembro de 2007.

Sua fauna é bastante rica, podendo ser encontrados com facilidade em suas praias, animais como elefantes-marinhos, focas-de-weddell, lobos- marinhos e focas-caranguegeiras. Sua avifauna é também bastante variada com a presença de espécies como pinguim-papua, pinguimantártico, pinguim- rei, pinguim-macaroni, biguas, albatrozes, skuas, trinta-reis e pombas-docabo entre outras.

Nesta ilha foi montado um container refúgio brasileiro com capacidade para abrigar 6 pesquisadores. As atividades de preparação e acomodação do material coletado foram realizadas em barraca laboratório construída próximo ao refúgio para este fim. 


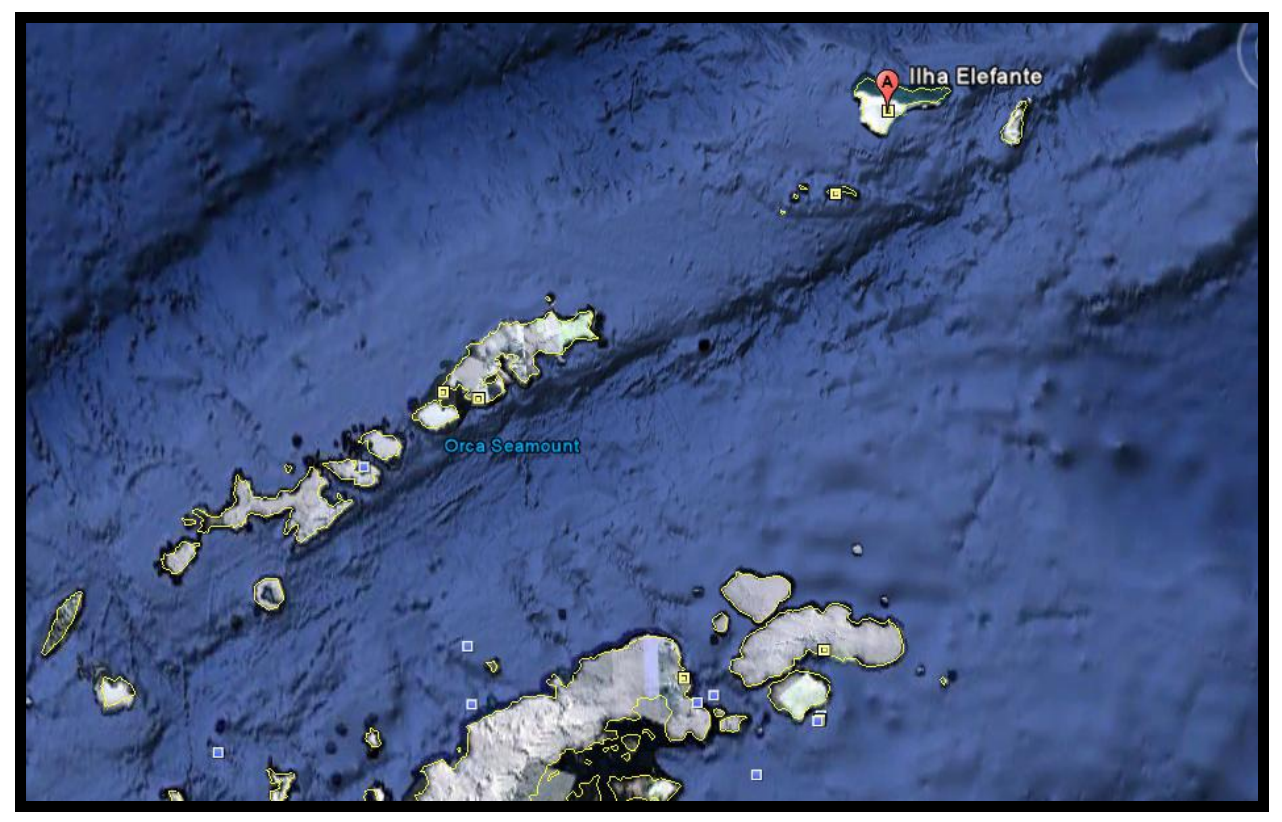

Figura 11 - Imagem de satélite mostrando a localização da Ilha Elefante (A). FONTE: programa GoogleEarthTM ([2010]).

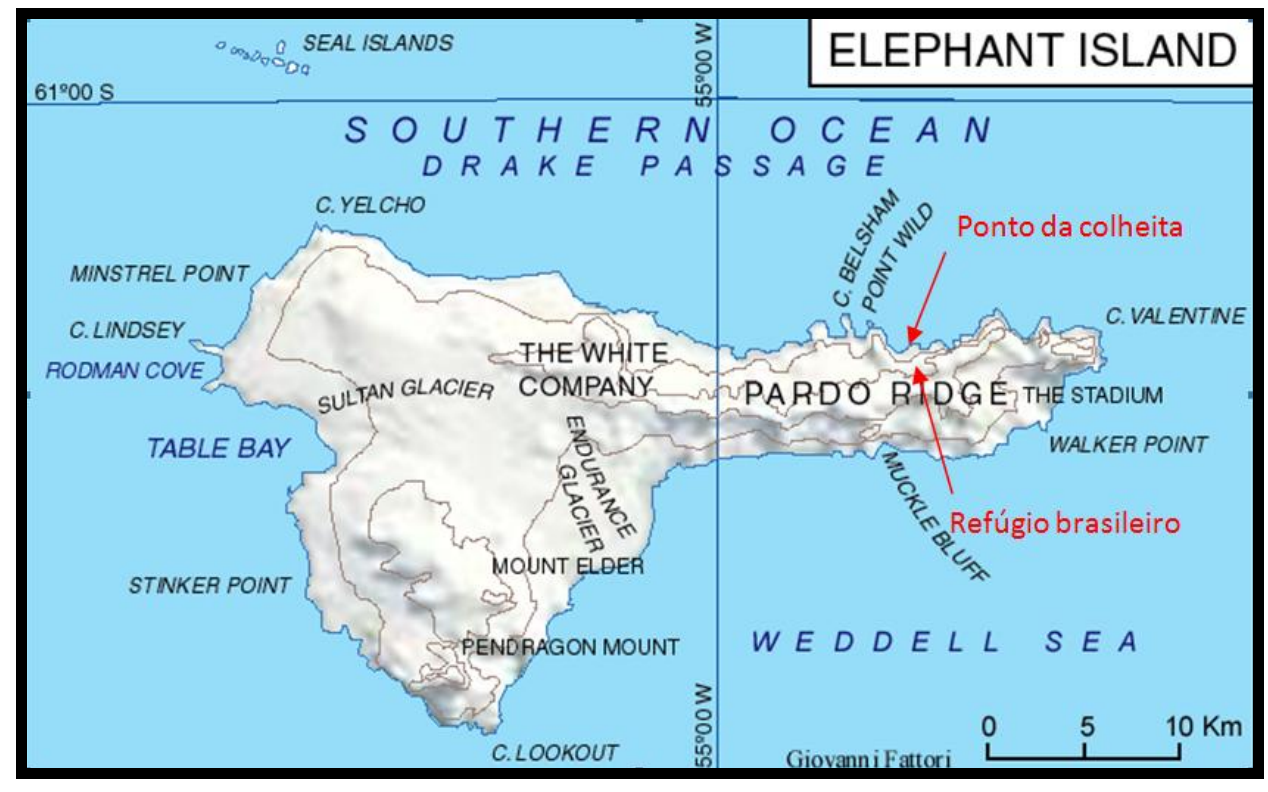

Figura 12 - Mapa da Ilha Elefante mostrando a localização do Refúgio para Estudos e o ponto de coleta de material FONTE: modificado de Wikipedia ([2010]). 


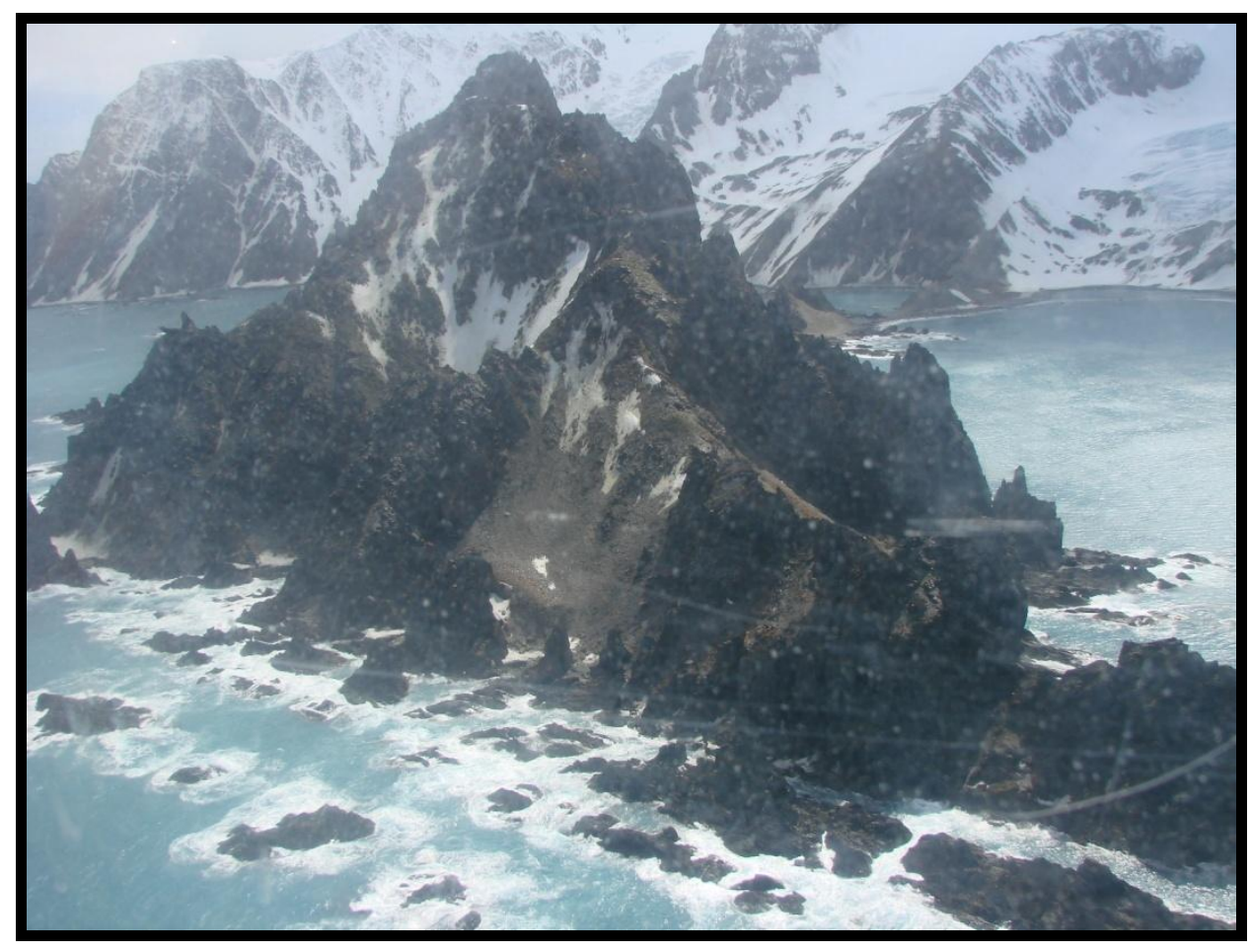

Figura 13 - Vista parcial da Ilha Elefante quando da chegada com o helicóptero.

No verão de 2008/2009 a coleta de amostras foi toda concentrada novamente na península Keller, local onde se encontra sediada a Base Antártica Brasileira Comandante Ferraz (62 $08^{\prime}$ S, $58^{\circ} 25^{\prime} \mathrm{W}$ ) nos mesmos pontos utilizados durante o ano de 2006. Alguns pinguins foram também capturados neste período durante o deslocamento da equipe entre as áreas de coleta. O período de coleta para a expedição do verão de 2008/2009 foi de 03 de dezembro de 2008 a 17 de março de 2009.

\subsubsection{Coleta de Amostras}

Durante as três expedições para coleta de material foram amostrados 283 pinguins. Essas aves foram capturadas com a utilização de puçás com boca de $60 \mathrm{~cm}$ de diâmetro, saco de $1 \mathrm{~m}$ de comprimento e cabo de $1,8 \mathrm{~m}$.

As capturas foram direcionadas apenas a indivíduos vagantes, ou seja, aves que não estavam nas proximidades de ninhais e que passavam a maior parte do tempo em atividades de alimentação ou de secagem seguida por arrumação das penas. Este cuidado foi tomado devido à 
época da coleta coincidir com a de acasalamento dessas aves, minimizando assim possíveis impactos negativos a atividade reprodutiva.

Após a captura os pinguins eram imediatamente manejados e as amostras coletadas. Antes da soltura os animais receberam uma marcação na região peitoral com a utilização de tinta atóxica que permitiu assim o reconhecimento das aves que já haviam passado pelo processo de coleta de material, evitando repetições.

Toda a coleta de amostras de material cloacal e oral foi realizada com auxílio de zaragatoas. Após a coleta, as amostras foram acondicionadas em criotubos com meio Eagle para transporte, este contendo 1,0\% de albumina bovina, 2000 unidades de penicilina $\mathrm{G}, 2,5 \mu \mathrm{g}$ de estreptomicina, $25 \mu \mathrm{g}$ de fungisona e $20 \%$ de glicerina.Uma duplicata destas mesmas amostras foi acondicionada e transportada em Trizol (Invitrogem Life Technologies, Carsbad, California, Estados Unidos). As amostras contendo conteúdo oral e cloacal foram acondicionadas em tambores de nitrogênio líquido no momento da coleta em campo até o transporte para o laboratório. Os tambores de nitrogênio foram acondicionados na câmara fria do porão do navio a - $10{ }^{\circ} \mathrm{C}$ para melhor conservação até chegada ao Brasil. Quando da chegada ao laboratório foram transferidas para freezer $-70^{\circ} \mathrm{C}$.

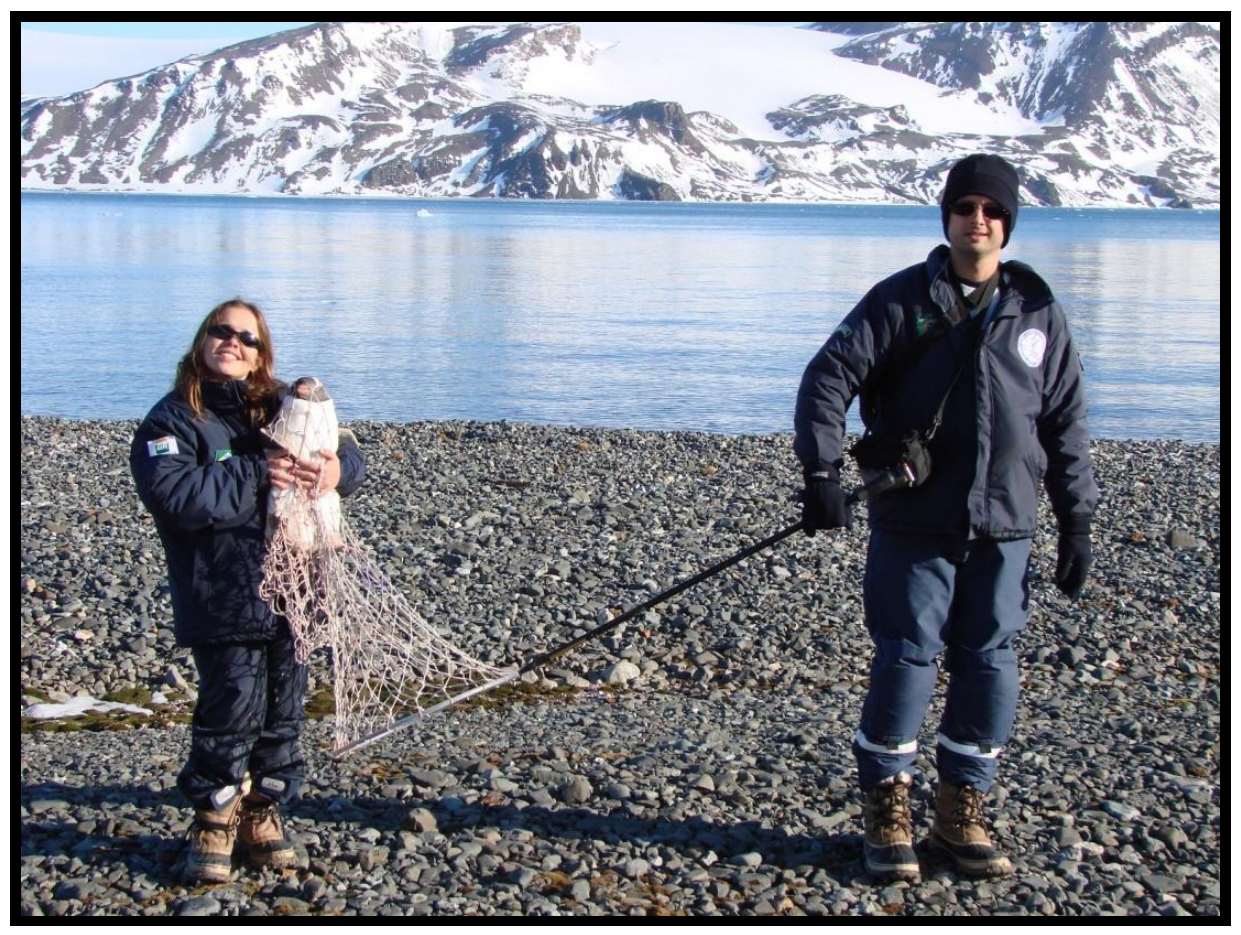

Figura 14 - Captura de exemplar de pinguim, próximo ao módulo de química. 


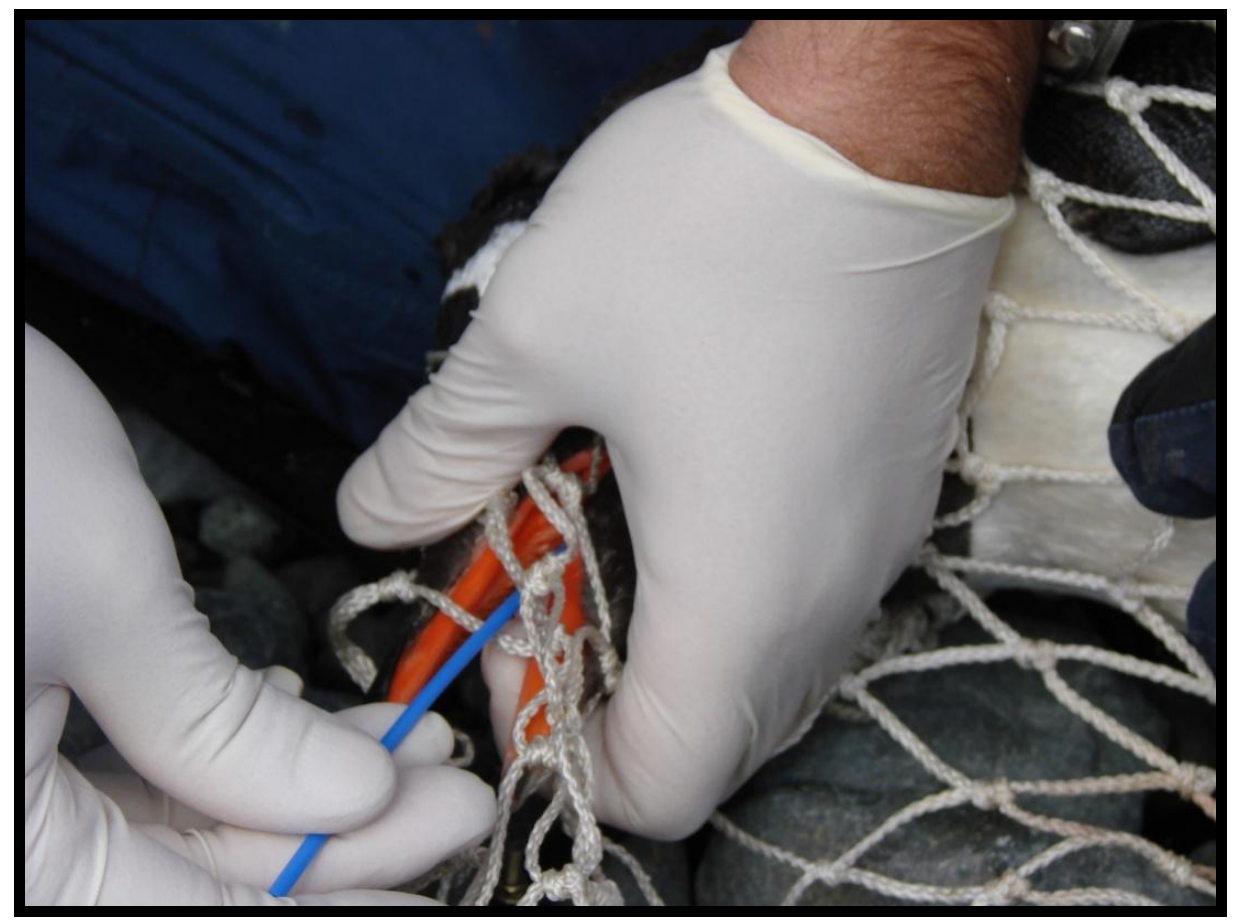

Figura 15 - Utilização de zaragatoa para coleta de material oral.

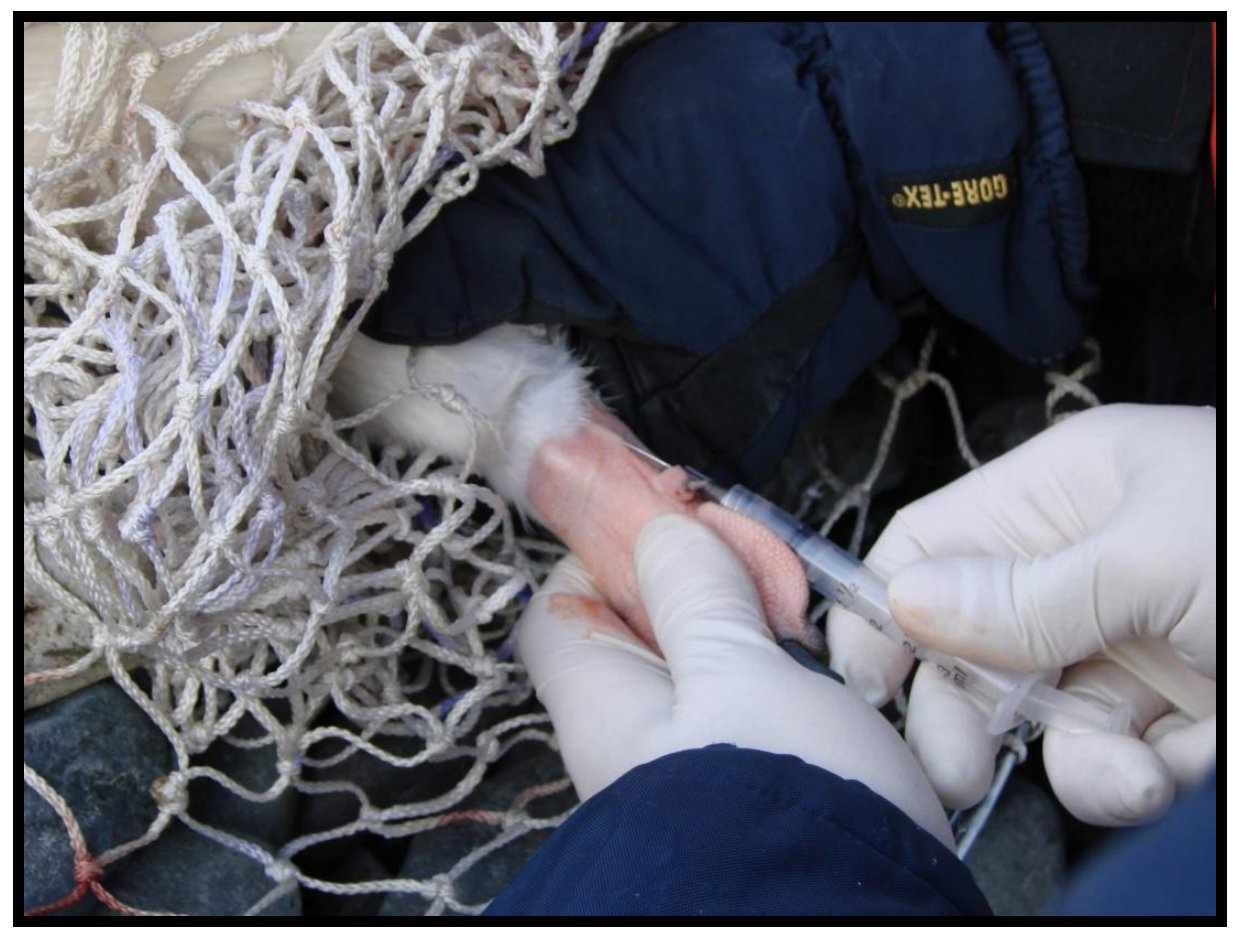

Figura 16 - Retirada de sangue da artéria femoral. 


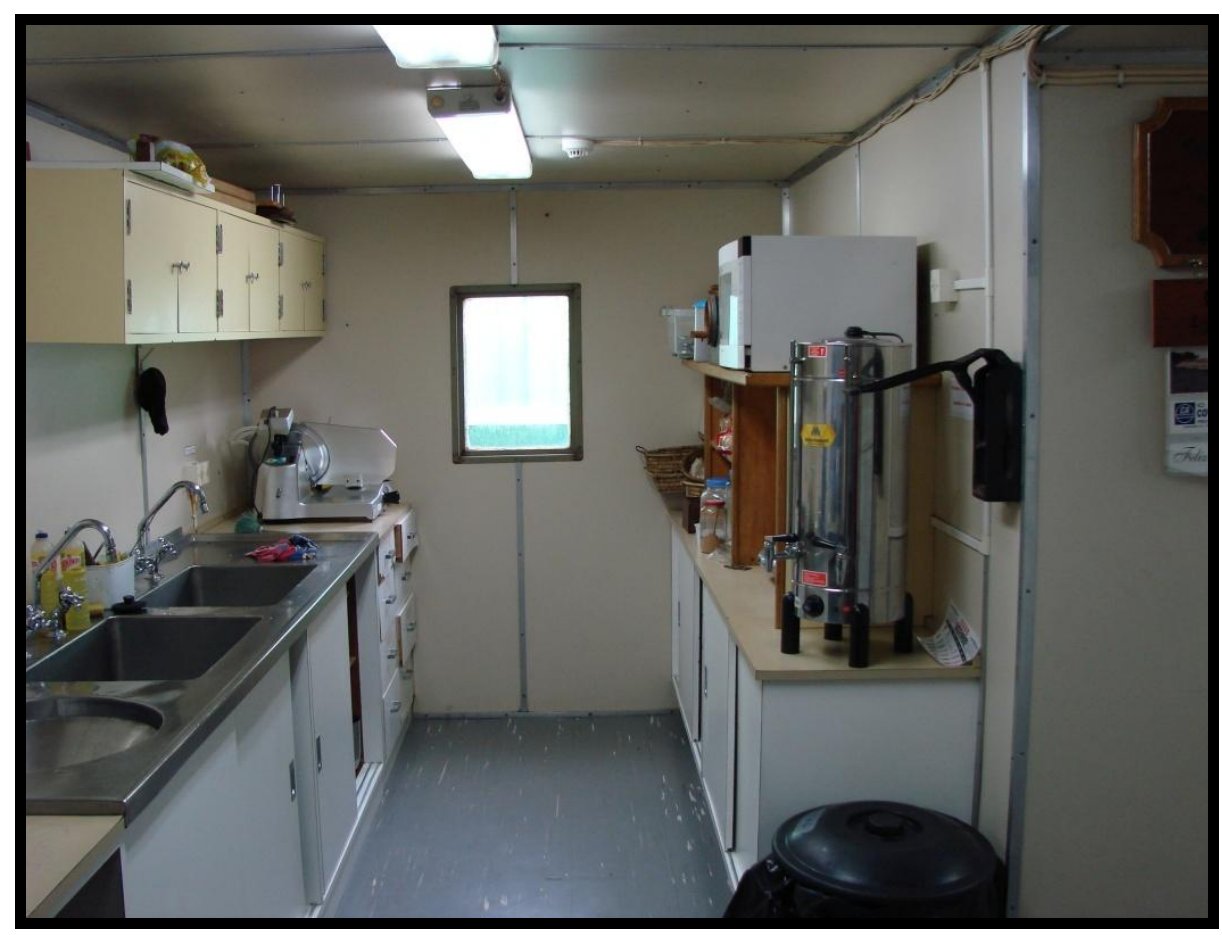

Figura 17 - Laboratório do módulo de química, Ilha Rei George.

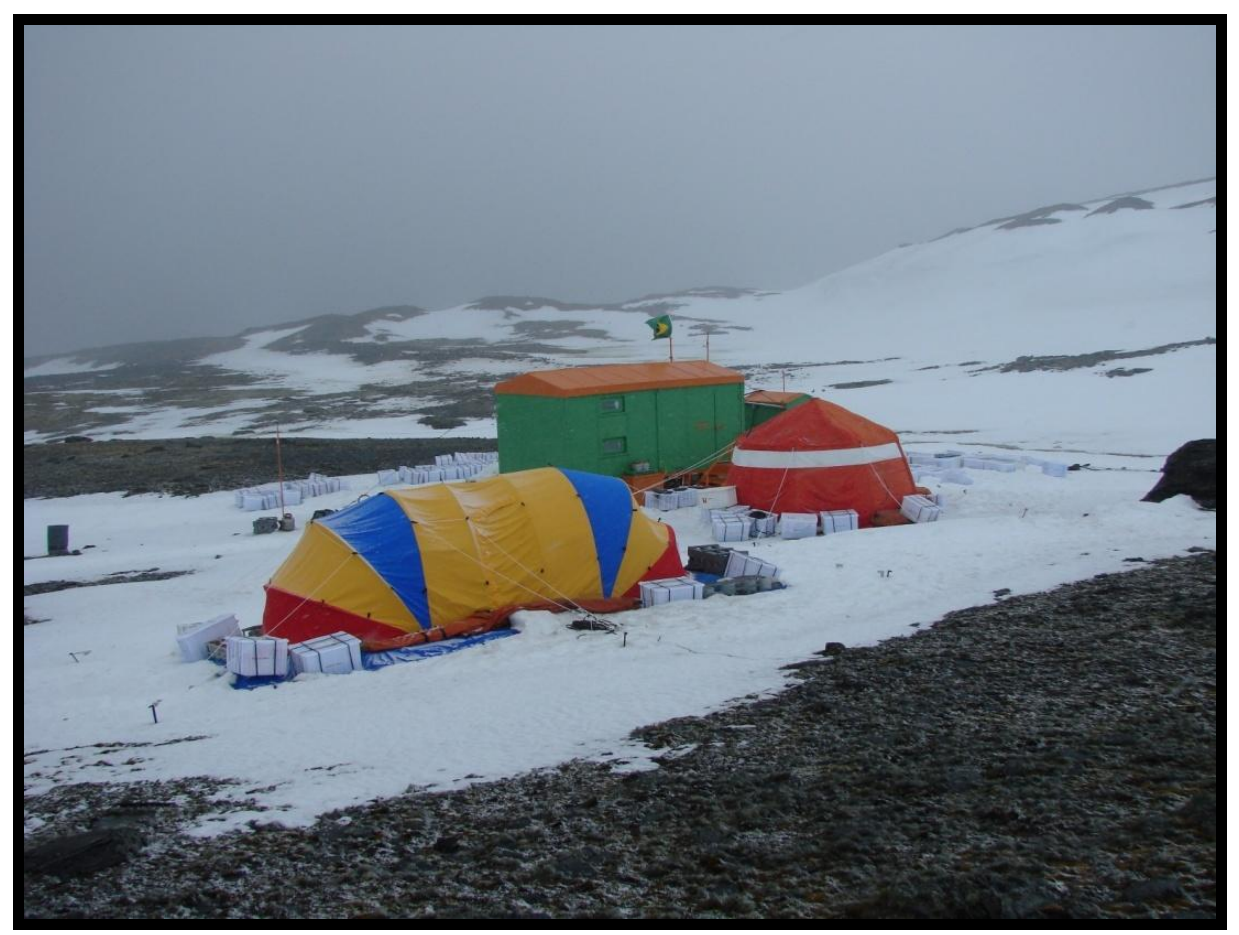

Figura 18 - Barraca laboratório (vermelha e branca) próximo ao refúgio, Ilha Elefante. 


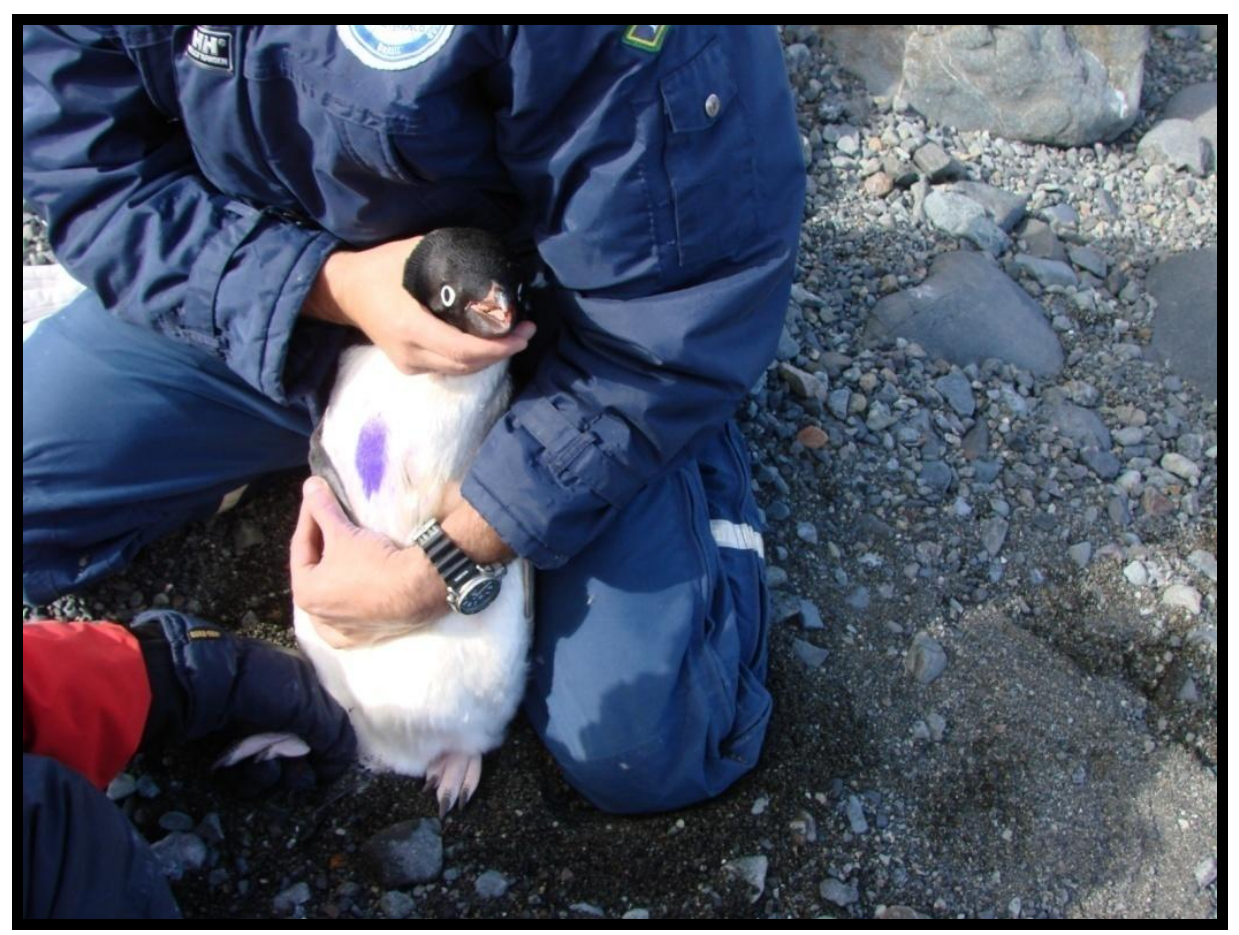

Figura 19 - Pinguim marcado antes da soltura com tinta atóxica.

\subsection{Extração de RNA das Amostras Virais}

A extração das 100 primeiras amostras colhidas no ano de 2006 foi realizada no laboratório do Módulo de Química da Estação Antártica Comandante Ferraz.

A extração de RNA das 183 amostras do ano de 2007 e 2008 foi feita no laboratório NB-2 (Laboratório de Biossegurança Nível 2) do Instituto de Ciências Biomédicas da Universidade de São Paulo. Após o descongelamento e homogeneização de cada amostra de material cloacal e oral transportadas em meio Eagle uma alíquota de $200 \mu 1$ foi retirada. A extração do material genético viral de cada alíquota foi realizada com a utilização do NucliSENS ® Iso Kit (bioMérieux, Lyon, France) com o protocolo on - board conforme instruções do fabricante.

\subsection{Transcrição Reversa}

Para a obtenção do cDNA (DNA complementar) foi utilizado o kit Hight Capacity cDNA Archive seguindo as orientações do fabricante (Appied Biosystems, Carlsbad, California, Estados Unidos), no qual, $50 \mu \mathrm{l}$ de RNA extraído foi diluído em tampão contendo 50 pMoles (Picomol 
$10^{-12} \mathrm{~mol}$ ) de Random primers e demais reagentes, obtendo-se um tampão de reação com $50 \mathrm{mM}$ (milimolar) de Tris-HCl [ com Potencial hidrogeniônico (pH) 8.3 a $25^{\circ} \mathrm{C} / 75 \mathrm{mM}$ de $\mathrm{KCl} / 3$ $\mathrm{mM}$ de $\mathrm{MgCl}_{2}$ (10x RT Buffer), $10 \mathrm{mM}$ de Dithiothreitol, $50 \mathrm{U}$ de MultiScribe RT enzyme, $02 \mathrm{U}$ de Inibidor de Ribonuclease, $1.5 \mathrm{mM}$ de dNTP (Deoxiribonucleosídeos 5’- trifosfatados) e água UltraPure (Gibco, Carlsbad, California, Estados Unidos) q.s.p (quantidade suficiente para). 100 $\mu$ 1. A mistura foi incubada a $25^{\circ} \mathrm{C}$ por 10 minutos (min) e $37{ }^{\circ} \mathrm{C}$ por 120 min no termociclador GeneAmp PCR System 9700 (Applied Biosystems). O cDNA foi armazenado em freezer $-70{ }^{\circ} \mathrm{C}$ até o momento de sua amplificação.

\subsection{Reacões de PCR para a Detecção Viral}

A amplificação foi realizada a partir de $5 \mu \mathrm{l}$ de cDNA acrescido de 25 pMoles dos primers FluA + (5'ctaagggetttcaccgaaga 3') e FluA - (5'cccattctcattactgcttc 3') (Claas et al.,1992), 2,5 U de taq DNA polimerase (Biotools, Madrid, Espanha), $10 \mathrm{mM}$ de cada dNTP e água ultra pura tratada com DEPC (dietilpirocarbomnato). A sequência alvo para os primers FluA+ e FluA - é uma região conservada do segmento genômico 8 (NS), para todos os subtipos virais do tipo A com 192 pares de base. As amostras foram amplificadas no termociclador 9700 (Applied Biosystems). O programa de ciclagem utilizado consistiu de 35 ciclos de 45 s a $94{ }^{\circ} \mathrm{C}$, $45 \mathrm{~s}$ a $56{ }^{\circ} \mathrm{C} 1 \mathrm{~min}$ a $72{ }^{\circ} \mathrm{C}$, e um ciclo final de $5 \min$ a $72{ }^{\circ} \mathrm{C}$. A Figura 20 mostra a localização dos primers no genoma viral. 


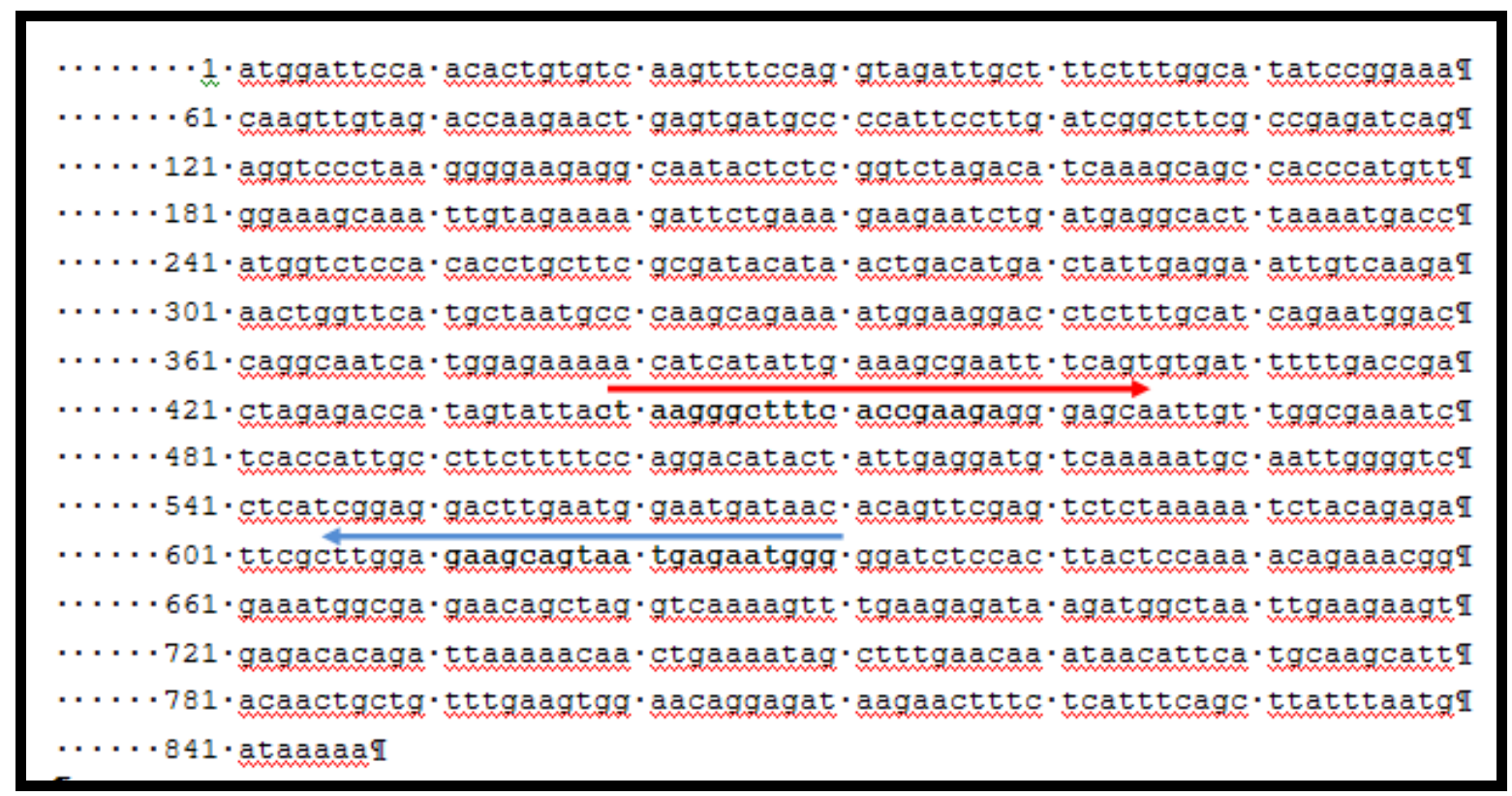

Figura 20 - Sequência completa do gene NS do segmento 8 (A/New York/3487/2009_H3N2), com a região complementar ao iniciador em negrito. A seta indica a direção de síntese dos iniciadores (vermelho FluA+ e azul FluA -). Produto esperado no tamanho de 192 pares de bases.

\subsection{Eletroforese em Gel de Agarose}

Para a preparação desta etapa do experimento em um volume de $15 \mu 1$ do produto amplificado de cada amostra dos 283 pinguins foi adicionado $3 \mu 1$ de corante para amostra $6 \mathrm{X}$ (azul de bromofenol 0,25\% e ficol tipo 400 15\%), seguindo-se análise por eletroforese horizontal em gel de agarose 1,2\% (Invitrogem Life Technologies), em tampão TAE (40 mM Tris-acetato pH 8,0, 1 mM EDTA- Ácido etilenodiaminotetracético). Os géis de agarose foram marcados com brometo de etídio na concentração de $0,5 \mu \mathrm{g} / \mathrm{ml}$ (mililitro) (Invitrogem Life Technologies). Após a corrida de aproximadamente 20 minutos, as bandas foram visualizadas por iluminação com luz ultravioleta (uv) e o gel foi fotografado.

\subsection{PCR em Tempo Real}

A amplificação em tempo real foi efetuada em placa de PCR de 96 orifícios. Para a realização desta etapa foi utilizado o "Kit de detecção da Invitrogem Universal PCR Master Mix" com os primers Influenza A INFA_F (5'gac cra tcc tgt cac ctc tga c 3') e INFA_R (5'agg gca tty 
tgg aca aak cgt cta 3'). A sequência alvo para os primers INFA Fe INFAR é uma região conservada do segmento genômico 7 que codifica as proteínas M1 e M2 da matriz protéica para todos os subtipos virais do tipo A, com 106 pares de base. O protocolo consiste na utilização $3 \mu 1$ de cDNA diluído em tampão 20 mM de Tris- $\mathrm{HCl}$ [pH 8.4] / $50 \mathrm{mM}$ de $\mathrm{KCl} / 2$ mM de $\mathrm{MgCl} 2$ (Biotools), 10 pMoles de cada primer (INFA_R e INFA_F), 10 pMoles da sonda M4169, $1 \mu 1$ de Taq DNA Polimerase (Biotools), $0.2 \mathrm{mM}$ de cada dNTP e água UltraPure q.s.p. $25 \mu \mathrm{l}$. As placas foram amplificadas no termociclador Real Time 3300 PCR System (Applied Biosystems). A amplificação foi efetuada a partir de uma etapa de desnaturação de $94{ }^{\circ} \mathrm{C}$ por $2 \mathrm{~min}$, seguida de 40 ciclos de $94{ }^{\circ} \mathrm{C}$ por $15 \mathrm{se}$, para desnaturação das fitas de DNA; $56{ }^{\circ} \mathrm{C}$ por $30 \mathrm{~s}$, para o pareamento dos primers (fase no qual, foram coletados os dados de fluorescência); e $72{ }^{\circ} \mathrm{C}$ por 15 s para a extensão das fitas de DNA. Como controle positivo foi incluído uma amostra de pulmão humano infectado com o vírus da influenza e como controle negativo foi utilizada água livre de DNA/RNAse esterilizada (Gibco).

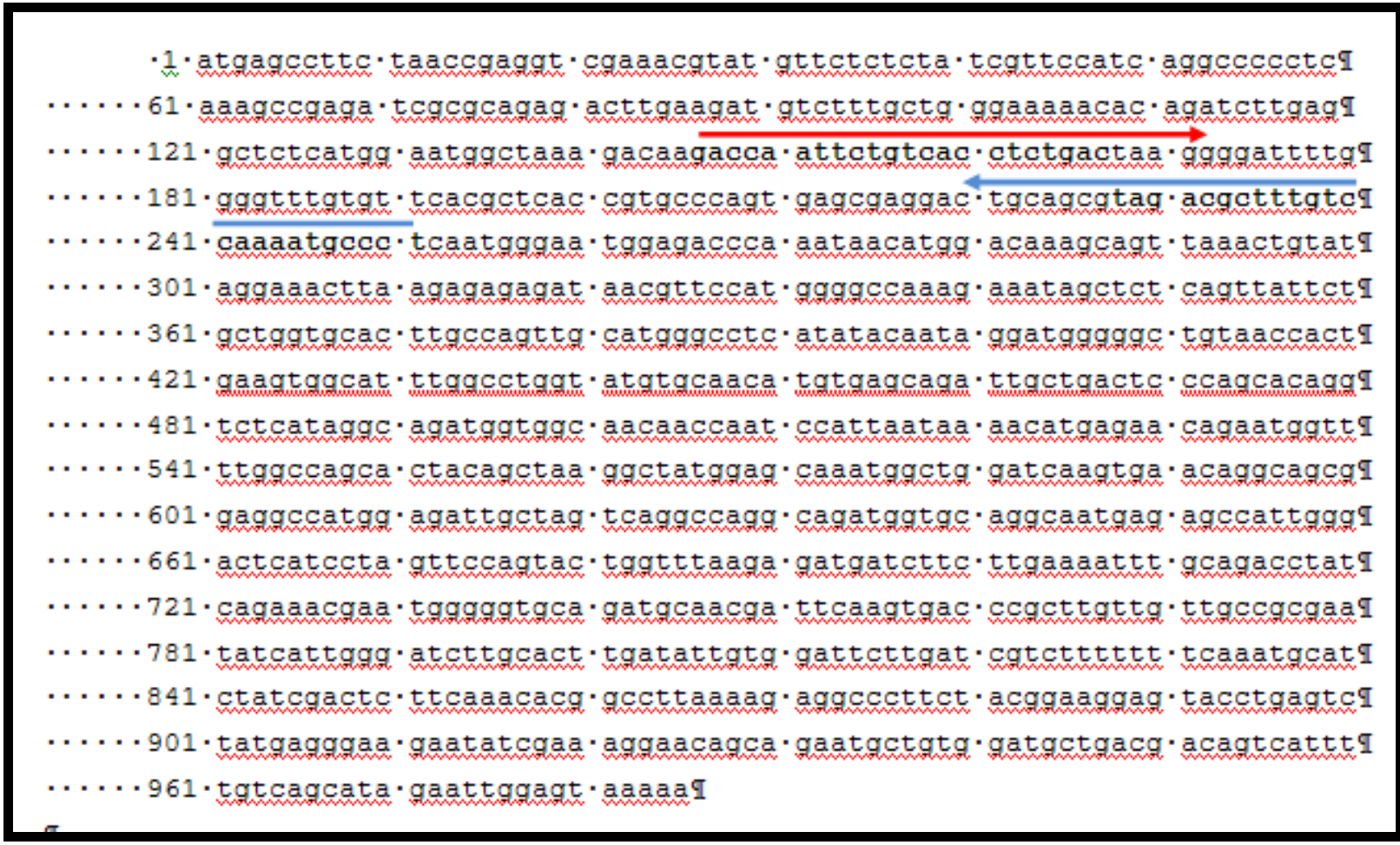

Figura 21-Sequência completa dos genes M1 e M2 contidos no segmento 7.(A/New York/3487/2009_H3N2), com a região complementar ao iniciador em negrito. A seta indica a direção de síntese dos iniciadores (vermelho INFA_F e azul INFA_R). Produto esperado no tamanho de 107 pares de bases 


\subsection{PCR GENESCAN (Gs)}

A PCR foi realizada a partir de $3 \mu \mathrm{L}$ do cDNA diluído em tampão Tris- $\mathrm{HCl} 20 \mathrm{mM}$ [pH 8.4] / 50mM de $\mathrm{KCl} / 1.5 \mathrm{mM}$ de $\mathrm{MgCl}_{2}$ (Applied Biosystems), 25 pMoles de cada primer FluA + (5'ctaagggctttcaccgaaga 3') marcado com FAM e FluA - (5'cccattctcattactgcttc 3') (Claas et al., 1992), 1 U de Taq DNA Polimerase (Applied Biosystems), $4 \mu \mathrm{L}$ de dNTP [1.25mM] e água MilliQ q.s.p. $25 \mu \mathrm{L}$. A sequência alvo para os primers FluA + e FluA - foi uma região conservada do segmento genômico 8 (NS) para todos os subtipos virais do tipo A. As amostras foram amplificadas em termociclador GeneAmp PCR System 9700 (Applied Biosystems), a partir de uma etapa $94{ }^{\circ} \mathrm{C}$ por 2 min seguida de 35 ciclos de $94{ }^{\circ} \mathrm{C} / 45 \mathrm{~min}, 54{ }^{\circ} \mathrm{C} / 45$ s e $72{ }^{\circ} \mathrm{C} / 45 \mathrm{~s}$ e uma etapa final de $72{ }^{\circ} \mathrm{C}$ por $5 \mathrm{~min}$. Os produtos amplificados foram estocados a $4{ }^{\circ} \mathrm{C}$.

\subsubsection{Detecção dos Produtos Amplificados}

Os produtos da PCR foram analisados e quantificados utilizando o Analisador Automático de DNA ABI-Prism modelo 310 (Applied Biosystems), com detecção para marcadores fluorescentes, utilizando o programa GeneScan. Um $\mu$ do produto da PCR foi misturado com $11 \mu \mathrm{l}$ de formamida deionizada e $0,75 \mu \mathrm{l}$ de sizestandard (GeneScan TAMRA ${ }^{\mathrm{TM}} 500$ ). A inclusão do padrão de peso molecular em cada amostra permitiu a compensação de eventuais variações que pudessem ocorrer entre as corridas eletroforéticas. Essa mistura foi colocada no Termociclador para denaturação: $95^{\circ} \mathrm{C}$ por 3 min e imediatamente colocada em gelo até a análise no aparelho. Os produtos foram submetidos a corrida eletroforética no interior de um capilar medindo $47 \mathrm{~cm}$ de comprimento, preenchido por um polímero POP-4 (Applied Biosystems). A injeção da amostra no capilar durou $5 \mathrm{~s}$ e a eletroforese foi realizada durante $40 \mathrm{~min}$ a 15.000 volts (v) e $60^{\circ} \mathrm{C}$.

Os fragmentos marcados foram detectados por um feixe de laser e por uma câmara CCD utilizando-se um filtro virtual "A", que em seguida foram analisados pelo programa ABI 310 GeneScan (Applied Biosystems), produzindo eletroferogramas com dados quanto ao tamanho dos fragmentos em pares de bases (pb) e quanto à intensidade de fluorescência em Unidades Relativas de Fluorescência (URF). 


\subsection{Sequenciamento do Material Genético}

Os produtos da PCR em Tempo Real das amostras positivas foram purificados e posteriormente sequenciados. Para a purificação foi utilizado o método de precipitação por isopropanol, no qual $50 \mu \mathrm{l}$ do produto amplificado foi adicionado a um microtubo contendo 300 $\mu \mathrm{l}$ de isopropanol $75 \%$, centrifugado a $12000 \mathrm{~g}$ por $20 \mathrm{~min}$ à temperatura ambiente e o sobrenadante foi descartado. Houve mais uma lavagem com $200 \mu \mathrm{l}$ de etanol $75 \%$, seguido de uma última centrifugação de $8000 \mathrm{~g}$ por $8 \mathrm{~min}$, o sobrenadante descartado e o precipitado ressuspendido em $50 \mu \mathrm{l}$ de água livre de DNA/RNAse (Gibco).

Para a reação de sequenciamento do DNA, foi utilizado o BigDye Terminator Cycle Sequencing Ready Reaction Kit - Ampli Taq DNA Polymerase (Applied Biosystems), no qual 2 $\mu l$ de tampão de sequenciamento (save money-5X), $2 \mu 1$ de reagente de sequenciamento (KitBigDye Terminator), $3 \mu 1$ do primer (1p/mol), $1 \mu$ de água 56 estéril e $2 \mu 1$ do produto de qPCR purificado, totalizando um volume final de $10 \mu$, foram submetidos ao ciclo de seqüenciamento, no termociclador Eppendorf 2500: $96{ }^{\circ} \mathrm{C}$ por $1 \mathrm{~min}$, seguido de 25 ciclos de $94{ }^{\circ} \mathrm{C}$ por $45 \mathrm{~s}, 50$ ${ }^{\circ} \mathrm{C}$ por $54 \mathrm{~s} \mathrm{e} 72{ }^{\circ} \mathrm{C}$ por $2 \mathrm{~min}$. O sequenciamento foi realizado nos dois sentidos, ou seja, utilizando-se os dois primers e em triplicatas, a fim de identificar possíveis erros de leitura das bases. A detecção dos nucleotídeos marcados por fluorescência foi realizada no seqüenciador automático de DNA ABI PRISM 3100 (Applied Biossytems) A busca inicial de similaridade das sequências obtidas em relação ao controle positivo para influenza do tipo A foi comparada com outras disponíveis no GenBank da página do NCBI (National Center for Biotechnology Information no endereço eletrônico: http://www.ncbi.nlm.nih.gov) e foi realizada pelo programa BLAST versão 2.0, disponível no mesmo endereço.

\subsection{1 - Processamento e alinhamento das sequências obtidas com as do segmento 8 do vírus da influenza $A$.}

As sequências de nucleotídeos foram alinhadas juntamente com sequências adquiridas do GenBank do segmento 8 do vírus da influenza A, codificador das proteínas NS, para todas as variantes de HA e NA encontradas no banco de dados, tendo-se o cuidado de se eleger sequencias encontradas em aves, suínos e no homem. Utilizando o programa BioEdit v7.0.9 (1997-2007, Tom Hall, Ibis Biosciences Carlsbad, CA) as sequencias foram alinhadas e então 
convertidas para o programa MEGA versão 4.0 (Tamura et al., 2007). Os arquivos foram analisados, com o referido programa, tendo como resultado a obtenção do grau de similaridade entre as sequências, calculadas par a par.

Tabela 1 - Sequencias obtidas no GeneBank do segmento 8 do vírus da influenza A utilizadas para comparação com as amostras positivas de pinguins.

\begin{tabular}{|c|c|c|c|}
\hline $\mathbf{N}^{\circ}$ GENBANK & HOSPEDEIRO & TIPIFICAÇÃO & ANO \\
\hline CY003911 & ave & $\mathrm{H} 2 \mathrm{~N} 1$ & 1988 \\
\hline CY003926 & ave & H2N7 & 1986 \\
\hline CY003933 & ave & $\mathrm{H} 2 \mathrm{~N} 1$ & 1988 \\
\hline CY005807 & ave & H1N1 & 1976 \\
\hline GU186636 & ave & H1N1 & 1976 \\
\hline HQ200446 & ave & H5N1 & 2006 \\
\hline CY069593 & humano & H5N1 & 2004 \\
\hline HM440135 & suíno & H5N1 & 2007 \\
\hline AB265204 & ave & H5N1 & 2006 \\
\hline AF115288 & humano & H5N1 & 1997 \\
\hline AF400790 & ave & H9N2 & 1998 \\
\hline EF015555 & ave & H7N7 & 2003 \\
\hline GU053125 & humano & H7N7 & 2003 \\
\hline CY069497 & humano & H3N2 & 2009 \\
\hline EU097925 & humano & H1N2 & 2003 \\
\hline CY068738 & humano & H3N2 & 2009 \\
\hline CY069561 & humano & H3N2 & 2009 \\
\hline CY006415 & humano & H1N2 & 2003 \\
\hline CY069553 & humano & H1N1 & 2009 \\
\hline CY069545 & humano & H1N1 & 2009 \\
\hline CY072538 & humano & H1N1 & 2010 \\
\hline CY073769 & humano & H1N1 & 2009 \\
\hline HM461766 & suíno & H1N1 & 2008 \\
\hline EU258947 & suíno & $\mathrm{H} 2 \mathrm{~N} 3$ & 2006 \\
\hline GQ452239 & suíno & H1N1 & 2004 \\
\hline EU871917 & ave & H5N5 & 2000 \\
\hline GU050796 & ave & $\mathrm{H} 2 \mathrm{~N} 1$ & 2002 \\
\hline EU742892 & ave & H7N2 & 2001 \\
\hline CY060400 & ave & $\mathrm{H} 2 \mathrm{~N} 1$ & 2002 \\
\hline FJ432774 & ave & H1N1 & 2006 \\
\hline DQ090051 & ave & H7N1 & 2000 \\
\hline AB546192 & ave & H7N7 & 2008 \\
\hline FJ461600 & suíno & H5N2 & 2008 \\
\hline CY061606 & ave & H7N7 & 1976 \\
\hline HM060076 & ave & H10N1 & 2007 \\
\hline
\end{tabular}




\subsubsection{Análise Genealógica}

Os arquivos gerados pelos programas de alinhamento BioEdit v7.0.9 (1997-2007, Tom Hall, Ibis Biosciences Carlsbad, CA) e convertidos para o MEGA 4.0 (Molecular Evolutionary Genetics Analysis software), disponível no site http://www.megasoftware.net/mega.html (Tamura et al., 2007) foram utilizados para as análises genealógicas para as amostras de vírus da influenza. A árvore de máxima verossimilhança (maximum likelihood) com as sequências de vírus da influeza A foi gerada com uma busca heurística (heuristic search) com o algoritmo "Neighborn joining” e para verificar a sustentação de ramos nas topologias da árvore obtida. Análises de bootstrap com 1000 réplicas (Felsenstein, 1985) e reamostragem de 200 caracteres também realizadas com o programa MEGA 4.0.

\subsection{Inoculação em ovos embrionados}

Com a finalidade de isolamento do vírus da influenza A, as 283 amostras orais/cloacais foram inoculada em ovos embrionados no Laboratório de Virologia do “St. Jude Children's Research Hospital” em Memphis, Estados Unidos da América em março de 2008.

\subsubsection{Preparação dos Antibióticos}

Antes da inoculação das amostras, foi realizado o preparo da solução de antibióticos. Apesar de já existirem antibióticos no meio de transporte, um reforço foi necessário para evitar a proliferação de bactérias nos ovos embrionados.

Os antibióticos foram preparados para conter em $1 \mathrm{ml}, 200$ mil unidades de penicilina, 40 mil unidades de estreptomicina, 20 mil unidades de polimicina $\mathrm{B}$ e $5 \mathrm{mg}$ de gentamicina. $\mathrm{O}$ concentrado de antibiótico foi colocado em 100 ml de PBS estéril.

As amostras foram, então, misturadas em com a utilização de "vortex" e uma alíquota de $0,2 \mathrm{ml}$ foi retirada de cada uma delas em seringa de insulina já contendo $0,2 \mathrm{ml}$ da solução de antibióticos. 


\subsubsection{Preparação dos Ovos e Inoculação}

Os ovos foram inspecionados em ovoscópio para a avaliação de sua viabilidade. Todos os embriões mortos ou com pouca mobilidade foram descartados.

Após este procedimento os ovos foram marcados e aspergidos com álcool a 70\%. Os embriões possuíam 10 dias de incubação. Após a inoculação, os ovos foram incubados por mais 3 dias a $35^{\circ} \mathrm{C}$.

A inoculação foi realizada com seringas de insulina em aberturas previamente feitas com a utilização de uma lixadeira portátil. Cada uma das amostras foi inoculada na cavidade alantóica de dois ovos. A abertura feita na casca do ovo foi fechada com parafina líquida para evitar possíveis contaminações.

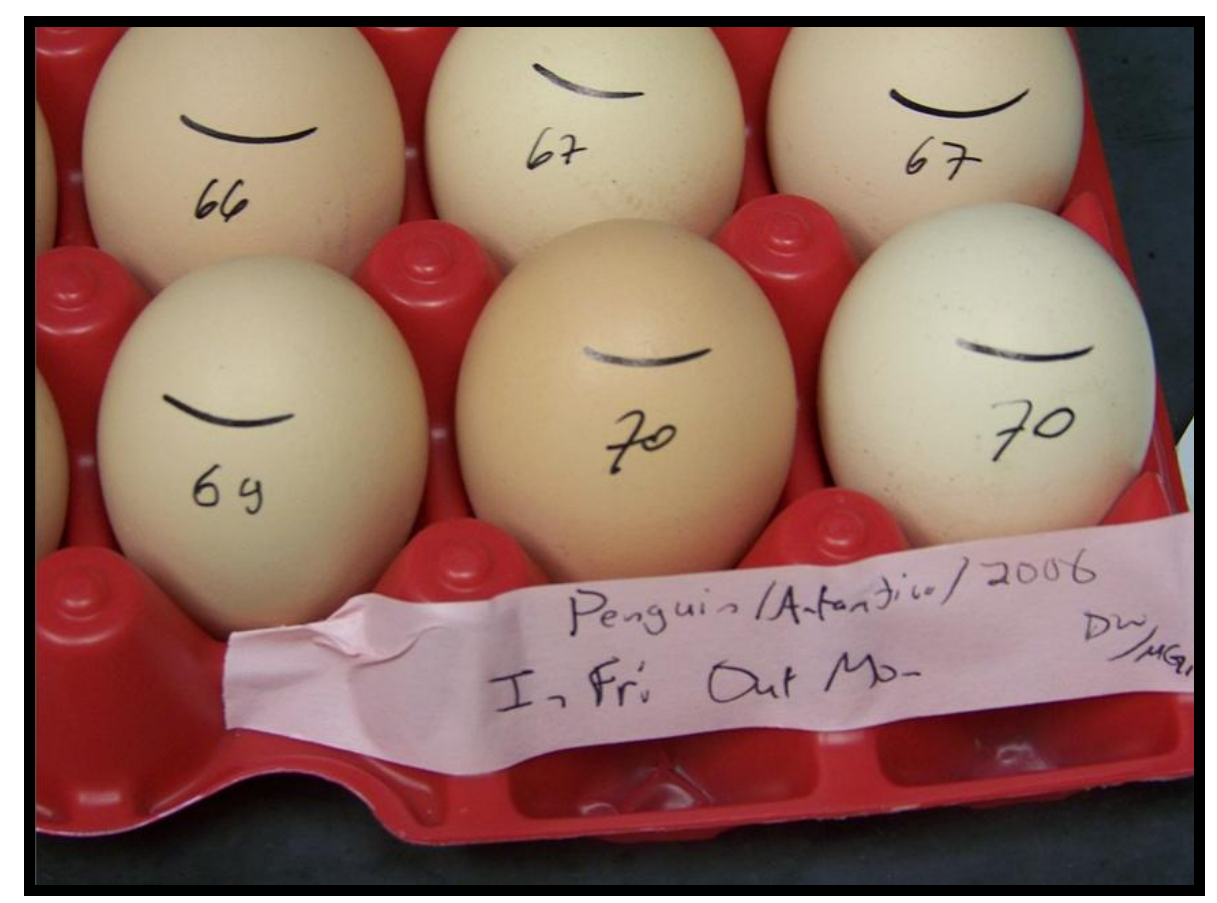

Figura 22 - Ovos marcados e prontos para a inoculação. 

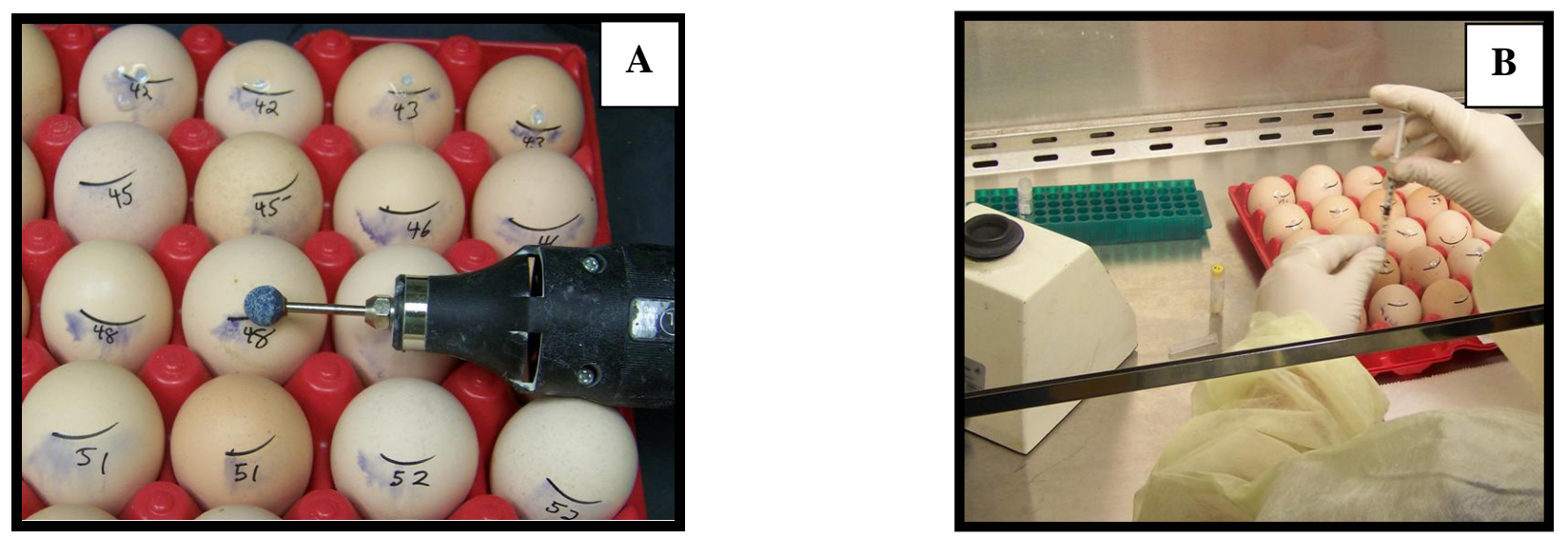

Figura 23 - A - Lixadeira portátil utilizada para fazer a abertura na casca dos ovos e permitir a entrada da agulha na cavidade alantóica. B- Inoculação de ovos embrionados com 0,2ml de amostra.

\subsubsection{Colheita do material incubado}

Após os 3 dias de incubação a $35^{\circ} \mathrm{C}$, os ovos foram inspecionados quanto à saúde dos embriões e aqueles que estavam mortos foram marcados. Os ovos foram, então, colocados em geladeira a $4{ }^{\circ} \mathrm{C}$ por 12 horas. $\mathrm{O}$ resfriamento mata o embrião e facilita a colheita do líquido alantóico devido à contração dos vasos sanguíneos do interior do ovo, prevenindo a contaminação do fluido alantóico com sangue do embrião.

Antes da colheita foi realizada uma amostragem de cada ovo para a verificação da existência viral. Para isso, a parafina que cobre a abertura implantada na casca do ovo foi derretida para a retirada de uma amostra de aproximadamente 1,5 $\mathrm{ml}$. Com o auxílio de pipetas Pasteurs esta alíquota foi acondicionada em um tubo de micro centrífuga. Este material foi utilizado em testes de esterilidade e em testes de hemaglutinação. O restante do líquido alantóico foi estocado para nova inoculação (segunda passagem) em ovos embrionados.

\subsubsection{Teste de esterilidade}

Uma placa de Petri contendo ágar sangue foi utilizada para realização do teste de esterilidade das alíquotas retiradas. 
Cada placa utilizada foi dividida para receber dez cultivados. Para isso, o fundo da placa foi divido em 10 partes com a utilização de uma caneta. Cada divisão recebeu uma alíquota de cerca de $2 \mu \mathrm{L}$ do fluido alantóico.

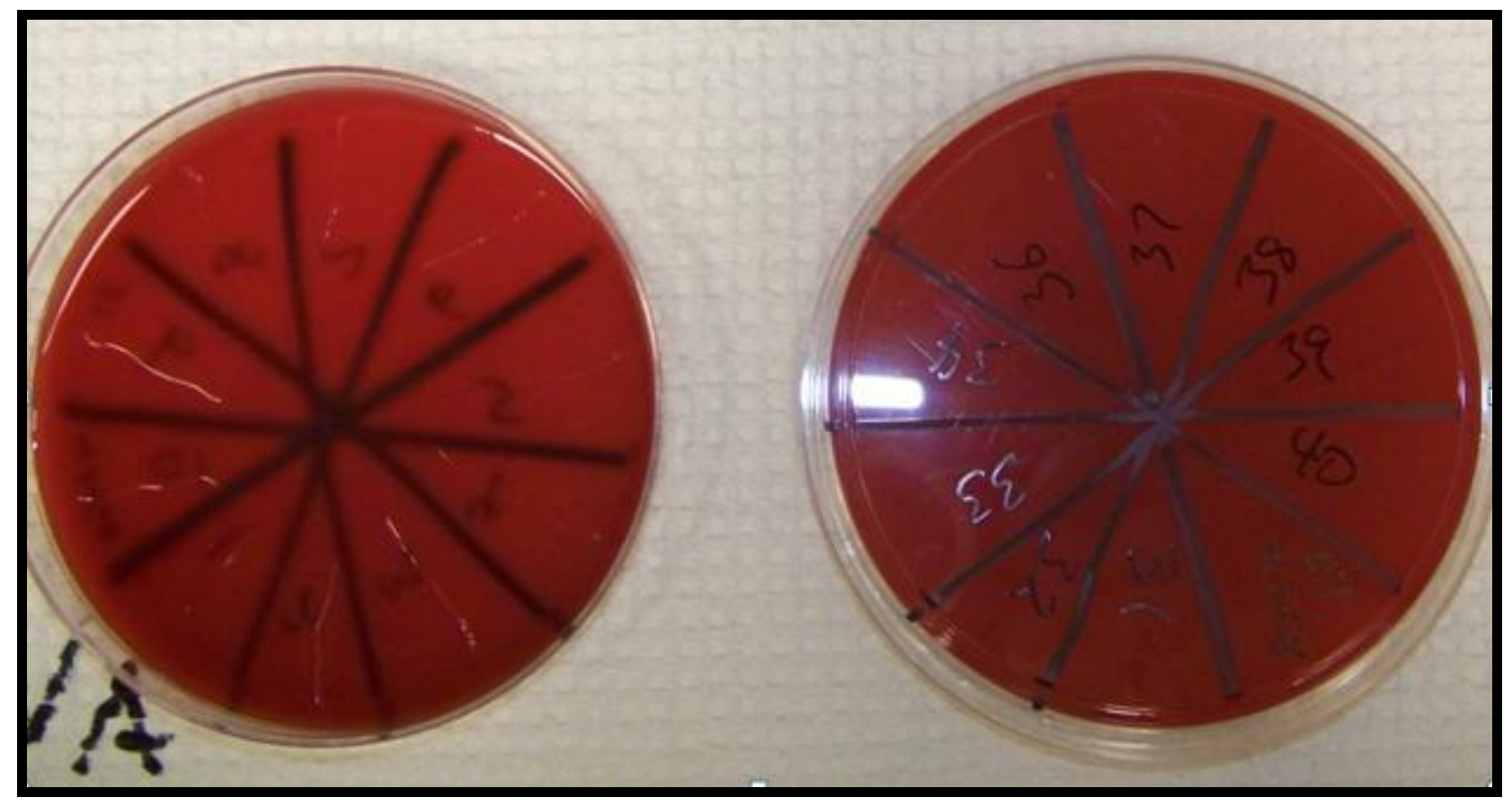

Figura 24 - Placas de Petri contendo ágar sangue para a execução dos testes de esterilidade dos cultivados.

\subsubsection{Teste de Hemaglutinação}

Para o teste de hemaglutinação $(\mathrm{H})$, uma alíquota de $50 \mu \mathrm{l}$ do cultivado foi colocada em uma cavidade da primeira linha de uma placa de titulação de 96 orifícios. Outra alíquota, de $100 \mu \mathrm{l}$, do mesmo cultivado foi colocada em uma cavidade da segunda linha, ou seja, na cavidade imediatamente abaixo da primeira alíquota. As linhas C e D contêm 50 $\mu$ l de PBS (Solução salina tamponada com fosfatos). Cada alíquota passa por uma diluição seriada até 1:4. Após a distribuição dos cultivados na placa, uma alíquota de $50 \mu \mathrm{L}$ de uma solução de $0,5 \%$ de hemácias de galinha em PBS foi distribuída nas linhas B, C e D. A leitura das placas foi realizada após meia hora. 
As linhas de E a $\mathrm{G}$ foram utilizadas por outras alíquotas do fluido alantóico, assim, cada placa pode ser utilizada por 12 cultivados, 6 em cada lado da micro placa . Este procedimento foi repetido para todas as 283 amostras de pinguins.

\subsubsection{Teste rápido para detecção de influenza}

Foi executado teste rápido para a detecção de antígeno viral para amostra 35. Para isso foi utilizado o kit comercial "Directigen Flu A+B" (BD: Becton, Dickinson and Company, Le Pont Claix, França). O teste foi realizado de acordo com as instruções do fabricante. 


\section{RESULTADOS}

\subsection{Amostras Coletadas}

Foram colhidas amostras de 283 exemplares de pinguins pertencentes a quatro espécies diferentes, o pinguim - papua Pygoscelis papua; о pinguim-adélia, Pygoscelis adeliae ; o pinguim-antártico $P$. Antarctica; e o pinguim - rei Aptenodytes patagonicus, este último raro para a região estudada tendo sido capturados somente dois exemplares.

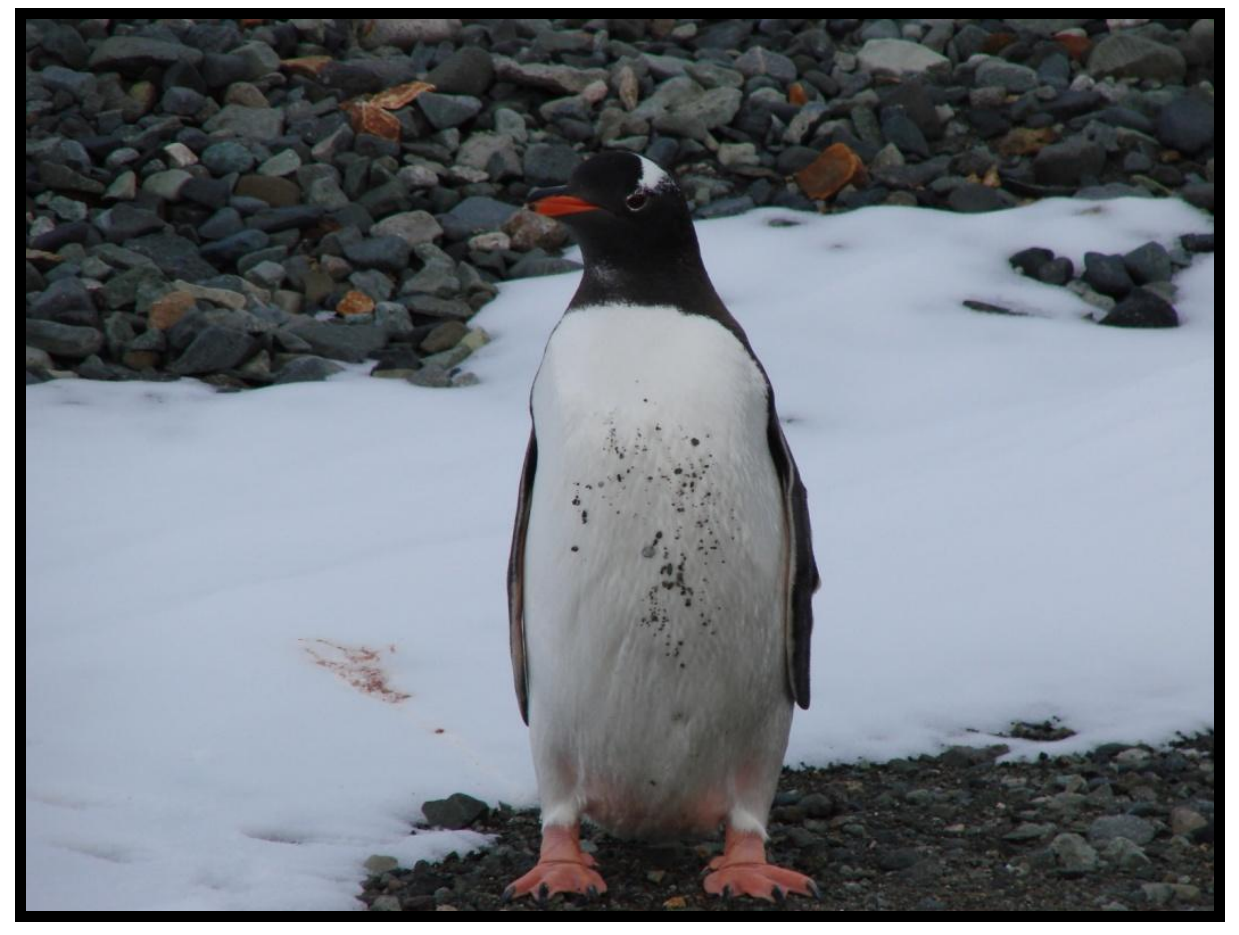

Figura 25 - Pinguim-papua, Pygoscelis papua 


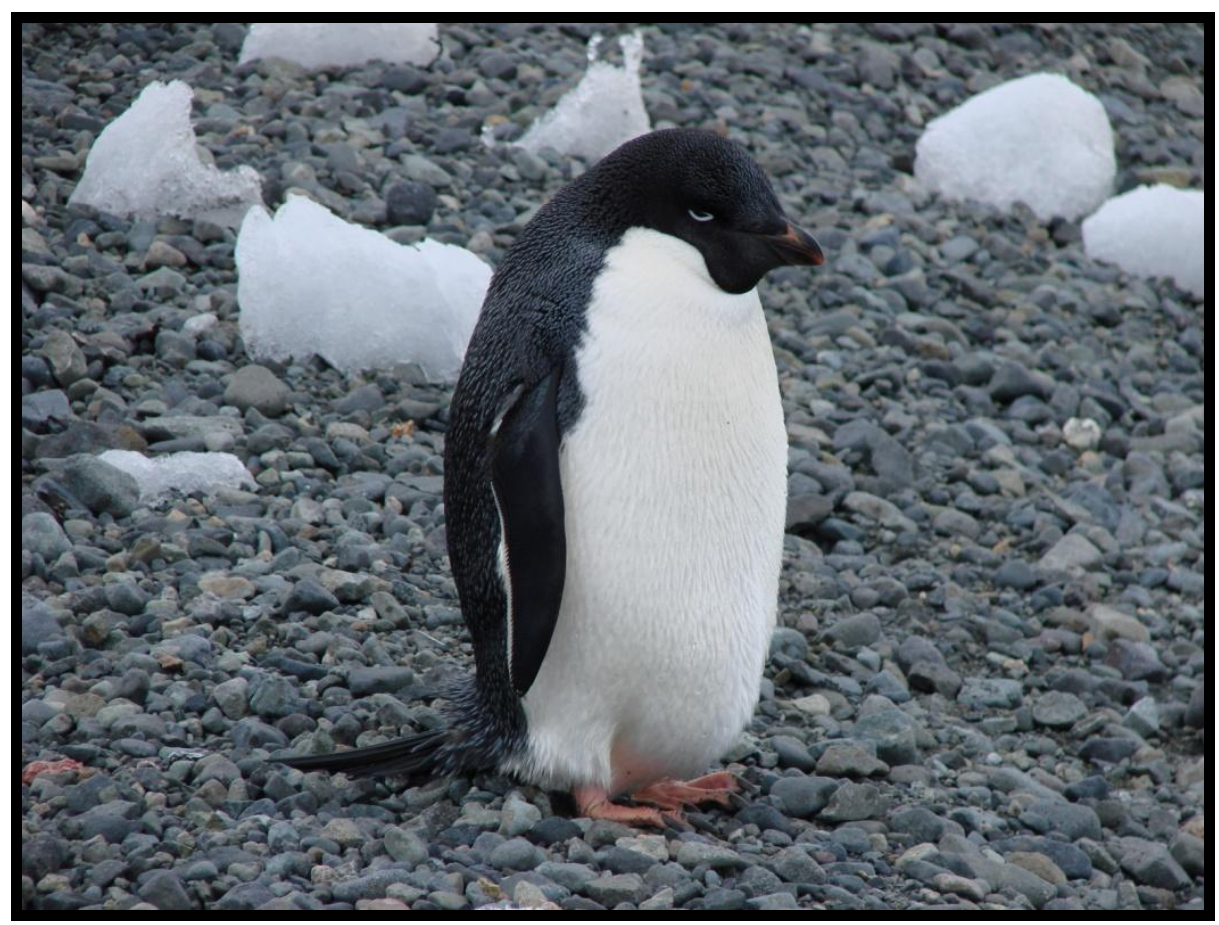

Figura 26 - Pinguim-adélia, Pygoscelis adeliae

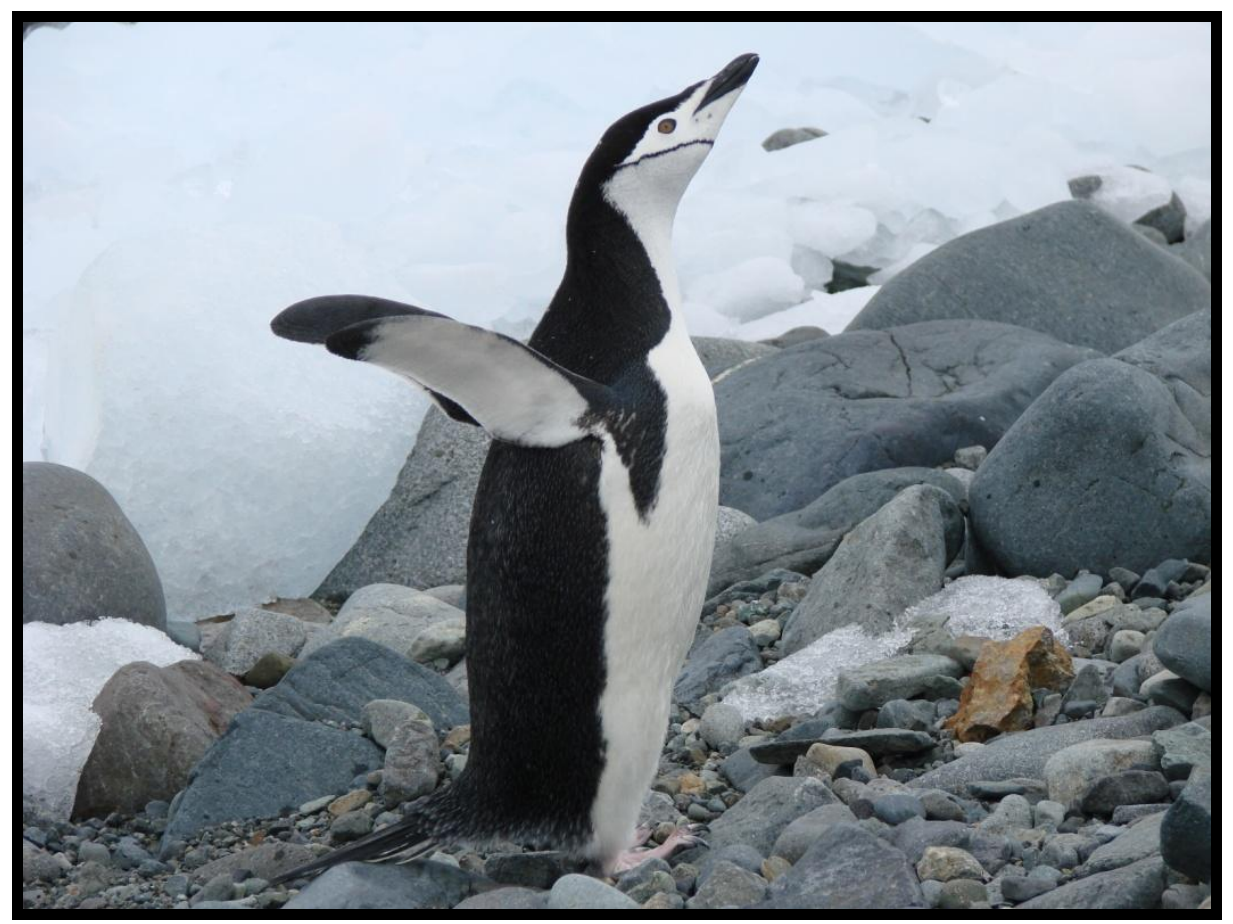

Figura 27 - Pinguim-antártico, Pygoscelis antarctica. 


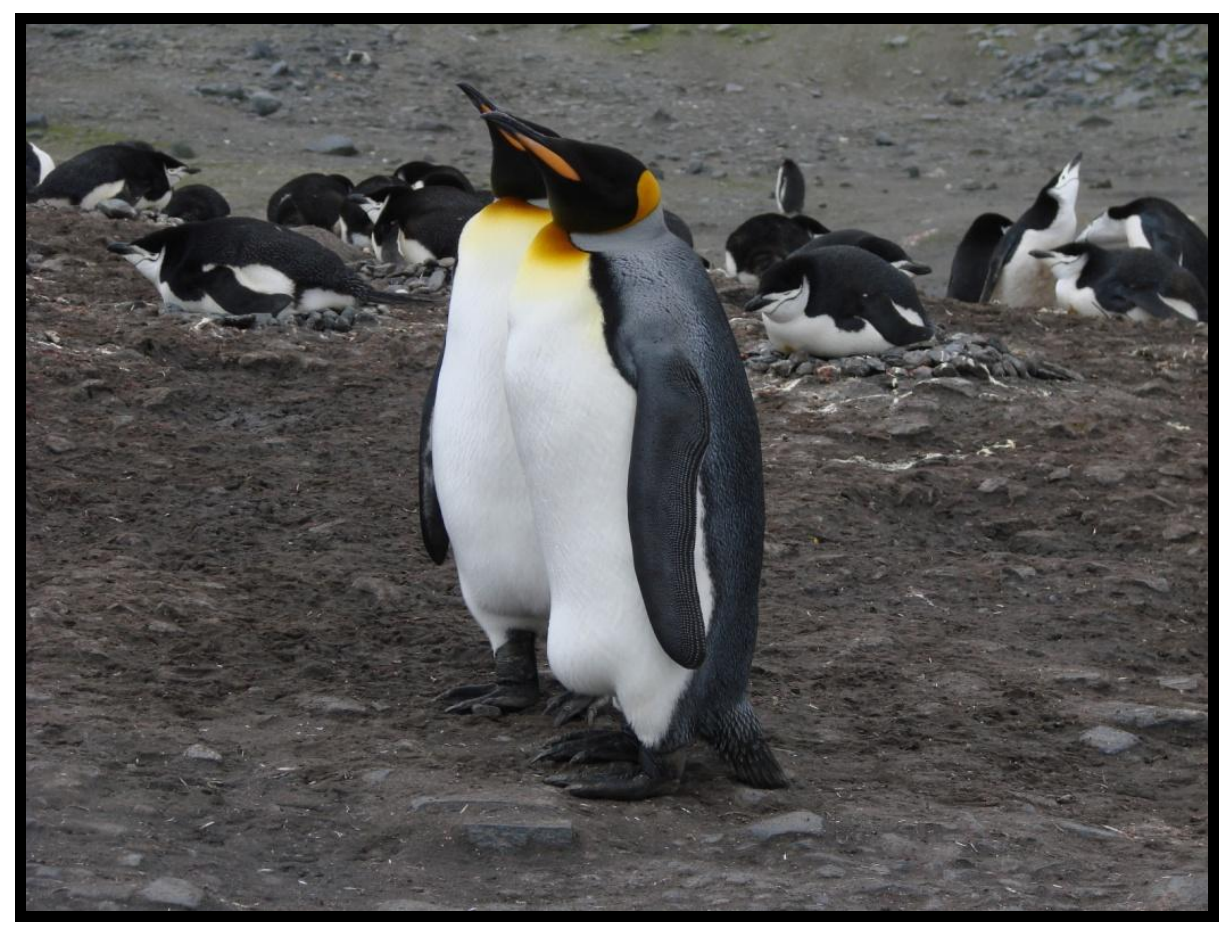

Figura 28 - Pinguim- rei, Aptenodytes patagonicus.

A proporção entre as espécies de pinguins amostradas durante a primeira expedição realizada no ano de 2006 bem como a quantidade de indivíduos pode ser observada na Tabela 2 e na Figura 29.

Tabela 2 - Número de pinguins amostrados por espécie no verão antártico de 2006/2007.

ESPÉCIE AMOSTRADA NÚMERO DE ESPÉCIMES AMOSTRADOS

\begin{tabular}{lc}
\hline Pygoscelis adeliae & 57 \\
\hline Pygoscelis antarctica & 8 \\
\hline Pygoscelis papua & 35 \\
\hline TOTAL & $\mathbf{1 0 0}$ \\
\hline
\end{tabular}




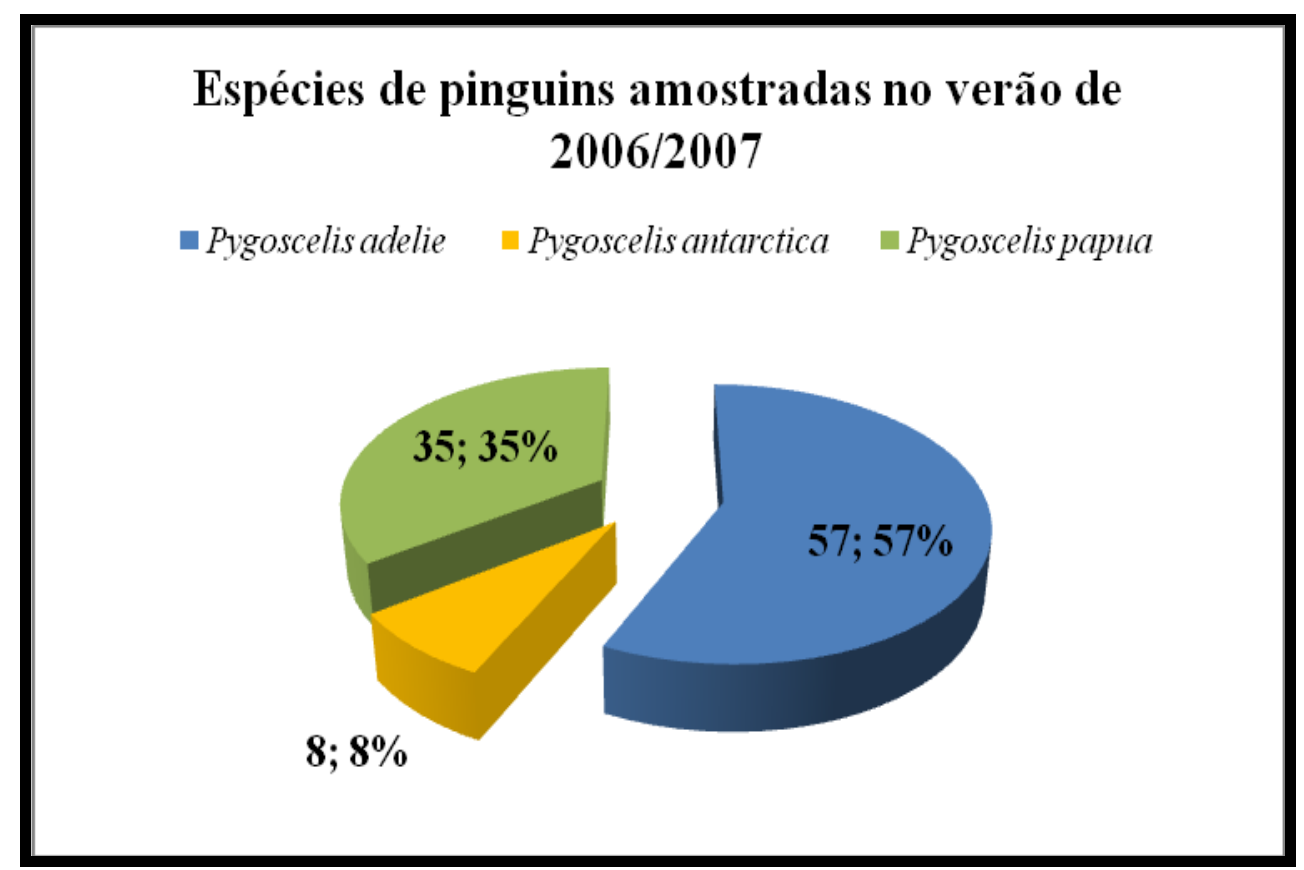

Figura 29- Proporção entre as espécies de pinguins amostradas durante o verão antártico de 2006/2007.

As coletas de amostras na estação de verão de 2007-2008, foram realizadas entre os dias 4 de dezembro e 8 de dezembro de 2007 na Ilha Elefante. No total foram coletadas 98 amostras de quatro espécies diferentes de pinguins antárticos. A proporção de cada espécie de pinguim amostrada durante esta temporada pode ser observada na Tabela 3 e na Figura 30.

Tabela 3 - Número de pinguins amostrados por espécie no verão antártico de 2007/2008.

\begin{tabular}{lc}
\hline ESPÉCIE AMOSTRADA & NÚMERO DE ESPÉCIMES AMOSTRADOS \\
\hline Aptenodytes patagonicus & 2 \\
\hline Pygoscelis antarctica & 65 \\
\hline Pygoscelis papua & 31 \\
\hline TOTAL & $\mathbf{9 8}$
\end{tabular}




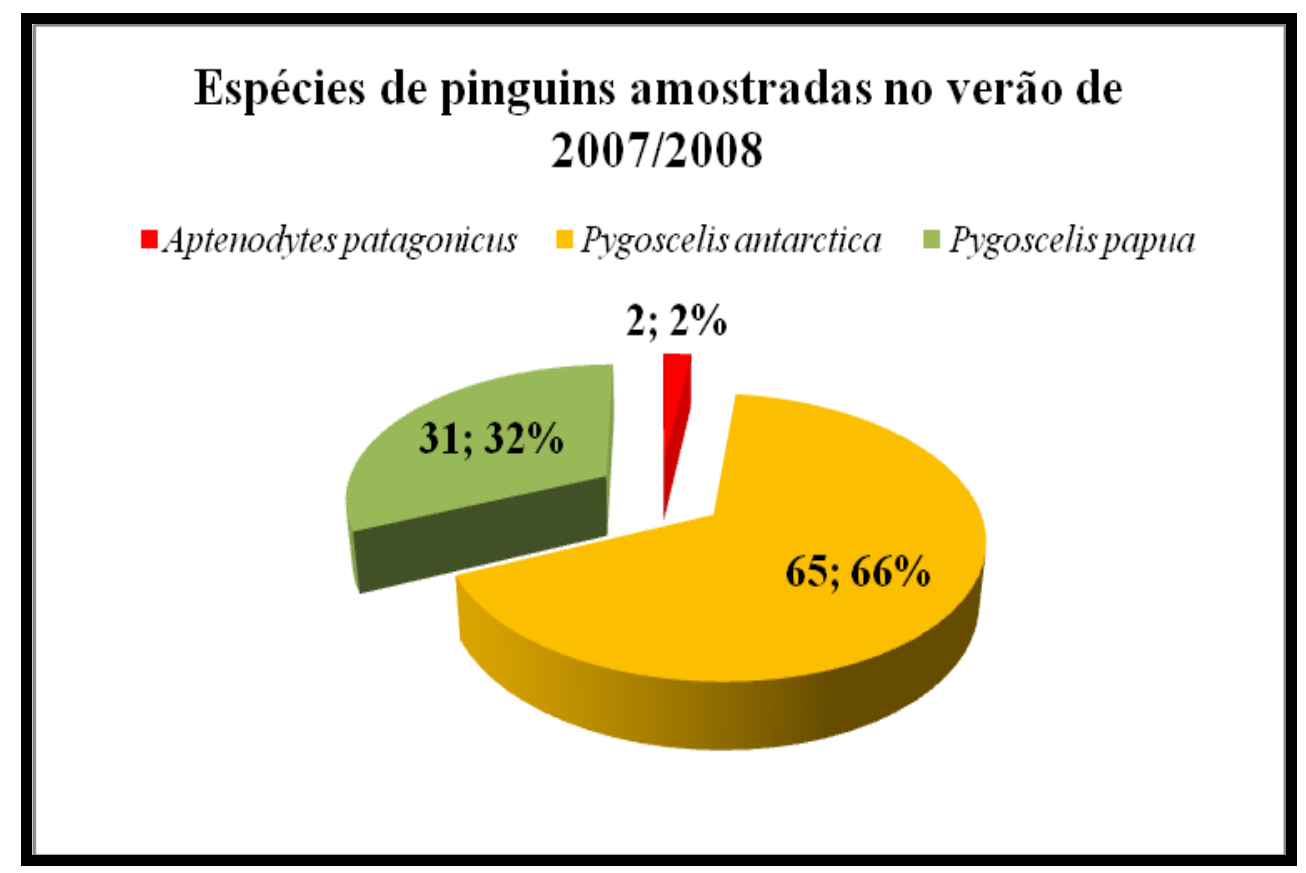

Figura 30 - Proporção entre as espécies de pinguins amostradas durante o verão antártico de 2007/2008

O período de coleta para a expedição do verão de 2008/2009 foi de 03 de dezembro de 2008 a 17 de março de 2009 onde foram coletadas 85 amostras de três espécies diferentes de pinguins antárticos. A proporção de cada espécie de pinguim amostrada durante esta temporada pode ser observada na Tabela 4 e na Figura 31.

Tabela 4 - Número de pinguins amostrados por espécie no verão antártico de 2008/2009.

\begin{tabular}{cc}
\hline ESPÉCIE AMOSTRADA & NÚMERO DE ESPÉCIMES AMOSTRADOS \\
\hline Pygoscelis adeliae & 48 \\
\hline Pygoscelis antarctica & 12 \\
\hline Pygoscelis papua & 25 \\
\hline TOTAL & $\mathbf{8 5}$ \\
\hline
\end{tabular}




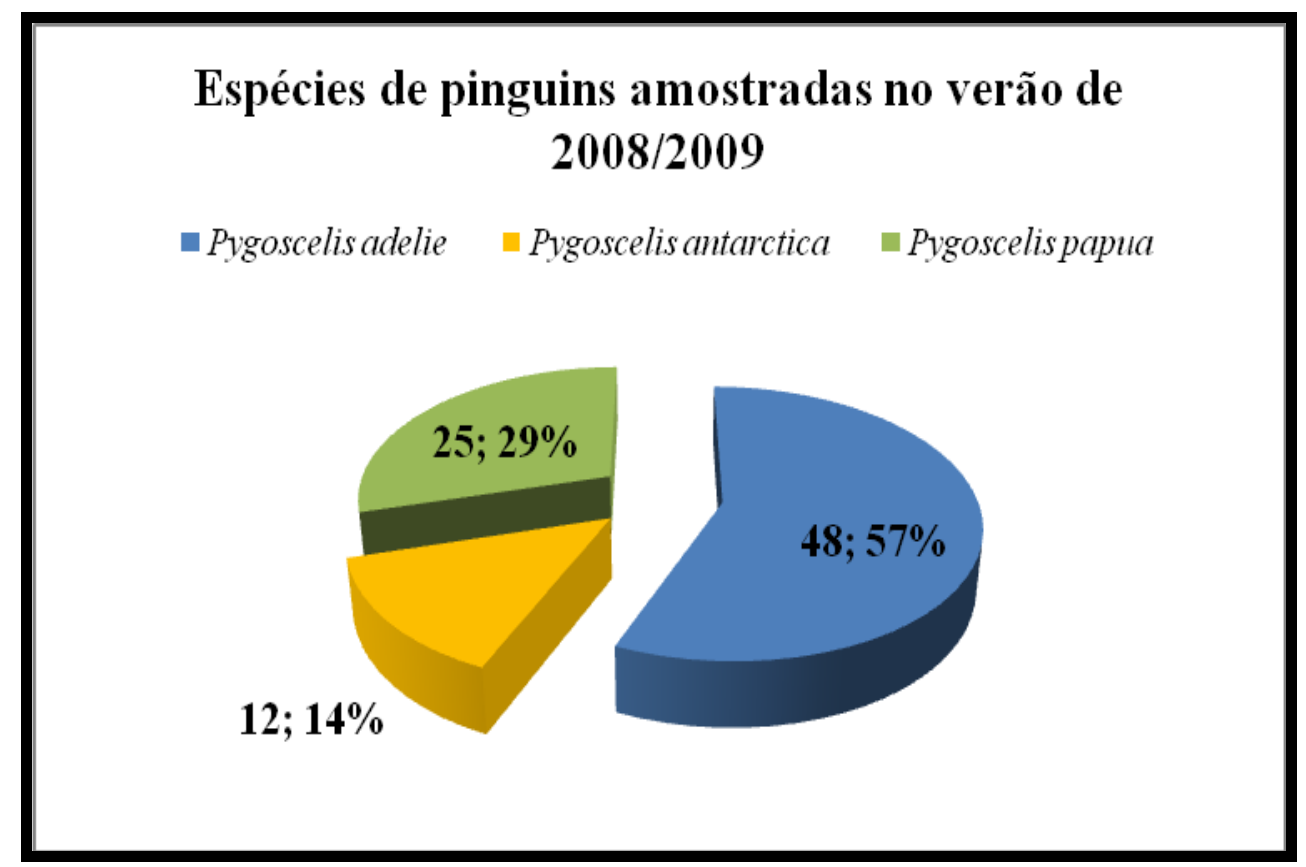

Figura 31 - Proporção entre as espécies de pinguins amostradas durante o verão antártico de 2008/2009.

A proporção de cada espécie de pinguim amostrada e o número de indivíduos capturados durante as três estações de verão antártico pode ser observada na Tabela 5 e na Figura 32.

Tabela 5 - Número de pinguins amostrados por espécie nas três estações de verão antártico.

\begin{tabular}{lc}
\hline ESPÉCIE AMOSTRADA & NÚMERO DE ESPÉCIMES AMOSTRADOS \\
\hline Aptenodytes patagonicus & 2 \\
\hline Pygoscelis antarctica & 85 \\
\hline Pygoscelis papua & 91 \\
\hline Pygoscelis adeliae & 105 \\
\hline TOTAL & $\mathbf{2 8 3}$
\end{tabular}




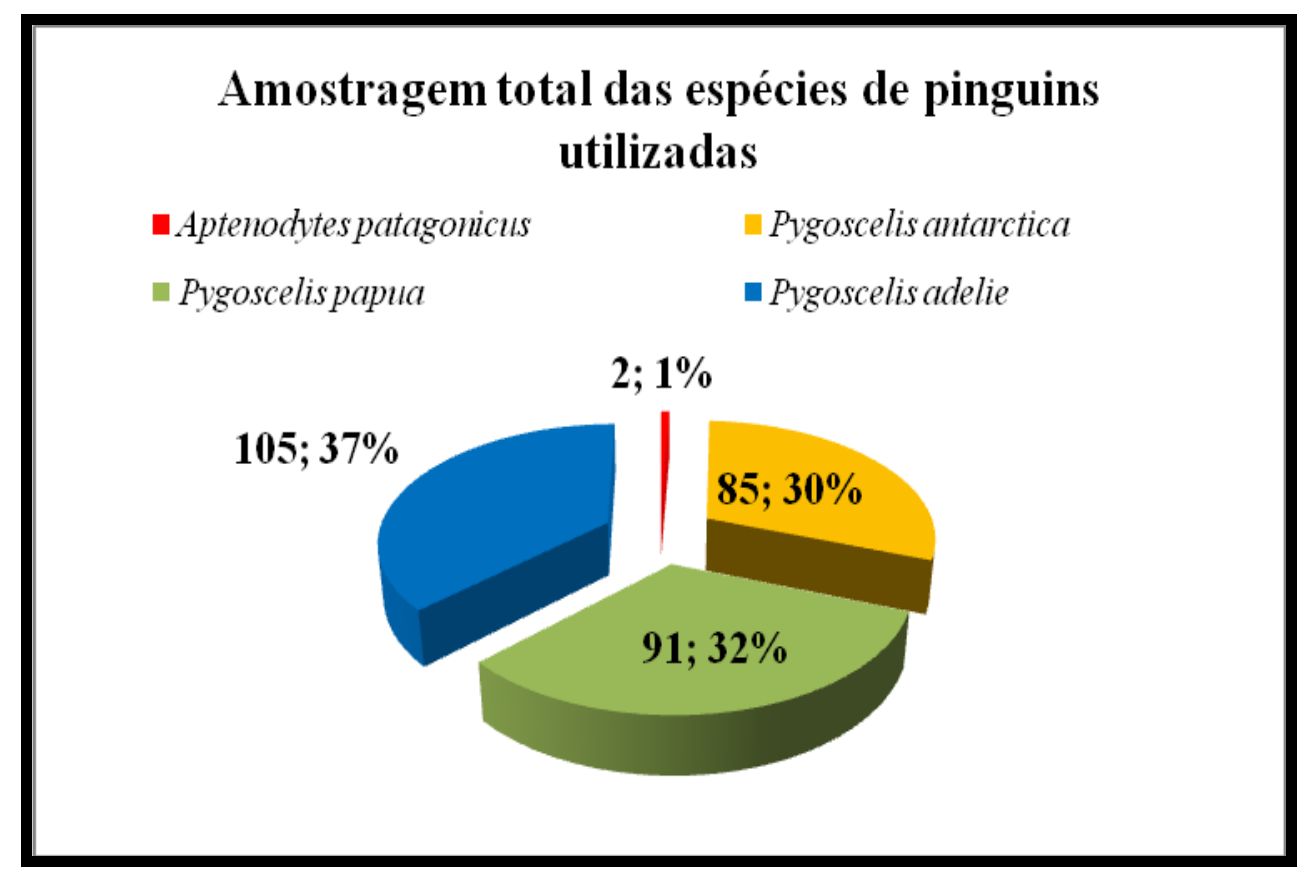

Figura 32 - Proporção entre as espécies de pinguins amostradas nos três verões antárticos

\subsection{Detecção Viral Através da Reação de PCR}

Foram realizadas reações de PCR para a detecção viral com leitura em gel de agarose para as 283 amostras colhidas. Obtiveram-se resultados positivos para as amostras de número 16/06, 21/06, 23/06, 42/06, 45/06, 50/06, 77/06 e 86/06. (Tabela 6). Das demais amostras testadas 35 apresentaram uma banda fraca próxima a 192 pares de bases, porém foram repetidas e não foi confirmada a sua positividade. As demais amostras foram todas negativas.

Tabela 6 - Amostras com resultado positivo testadas pelo método de PCR com visualização em gel de agarose.

(continua)

\begin{tabular}{cccccc}
\hline $\begin{array}{c}\text { Identificação } \\
\text { da amostra }\end{array}$ & Nome popular & Nome científico & $\begin{array}{c}\text { Data da } \\
\text { coleta }\end{array}$ & Local & Resultados \\
\hline $16 / 06$ & pinguim-adélia & $\begin{array}{c}\text { Pygoscelis } \\
\text { adeliae }\end{array}$ & $21 / 11 / 2006$ & Refúgio 1 & Pos. \\
\hline $21 / 06$ & pinguiim-papua & $\begin{array}{c}\text { Pygoscelis } \\
\text { papua }\end{array}$ & $21 / 11 / 2006$ & Refúgio 1 & Pos \\
\hline $23 / 06$ & pinguim-papua & $\begin{array}{c}\text { Pygoscelis } \\
\text { papua }\end{array}$ & $21 / 11 / 2006$ & Refúgio 1 & Pos \\
\hline $42 / 06$ & pinguim-papua & $\begin{array}{c}\text { Pygoscelis } \\
\text { papua }\end{array}$ & $23 / 11 / 2006$ & Punta Hennequin & Pos \\
\hline $45 / 06$ & pinguim-adélia & $\begin{array}{c}\text { Pygoscelis } \\
\text { adeliae }\end{array}$ & $27 / 11 / 2006$ & Módulo de Química & Pos \\
\hline
\end{tabular}


(conclusão)

\begin{tabular}{cccccc}
\hline $\begin{array}{c}\text { Identificação } \\
\text { da amostra }\end{array}$ & Nome popular & Nome científico & $\begin{array}{c}\text { Data da } \\
\text { coleta }\end{array}$ & Local & Resultados \\
\hline $50 / 06$ & pinguim-adélia & $\begin{array}{c}\text { Pygoscelis } \\
\text { papua }\end{array}$ & $27 / 11 / 2006$ & Módulo de Química & Pos \\
\hline $77 / 06$ & pinguim-adélia & $\begin{array}{c}\text { Pygoscelis } \\
\text { adeliae }\end{array}$ & $30 / 11 / 2006$ & $\begin{array}{c}\text { Entre Punta Plaza e o } \\
\text { Módulo de Química }\end{array}$ & Pos \\
\hline $86 / 06$ & pinguim-papua & $\begin{array}{c}\text { Pygoscelis } \\
\text { papua }\end{array}$ & $30 / 11 / 2006$ & $\begin{array}{c}\text { Entre Punta Plaza e o } \\
\text { Módulo de Química }\end{array}$ & Pos \\
\hline
\end{tabular}

Tabela 7 - Tabela das 35 amostras que apresentaram bandas fracas e foram novamente testadas pelo método de PCR com visualização em gel de agarose.

(continua)

\begin{tabular}{|c|c|c|c|c|c|}
\hline $\begin{array}{c}\text { Identificação } \\
\text { da amostra }\end{array}$ & Nome popular & Nome científico & $\begin{array}{c}\text { Data da } \\
\text { coleta } \\
\end{array}$ & Local & Resultados \\
\hline $01 / 07$ & $\begin{array}{l}\text { pinguim- } \\
\text { antártico }\end{array}$ & $\begin{array}{l}\text { Pygoscelis } \\
\text { antarctica }\end{array}$ & $04 / 12 / 2007$ & Ilha Elefante/Antártica & negativo \\
\hline 08/07 & pinguim-papua & $\begin{array}{l}\text { Pygoscelis } \\
\text { papua }\end{array}$ & $04 / 12 / 2007$ & Ilha Elefante/Antártica & negativo \\
\hline $13 / 07$ & $\begin{array}{l}\text { pinguim- } \\
\text { antártico }\end{array}$ & $\begin{array}{l}\text { Pygoscelis } \\
\text { antarctica }\end{array}$ & $04 / 12 / 2007$ & Ilha Elefante/Antártica & negativo \\
\hline $25 / 07$ & pinguim-papua & $\begin{array}{c}\text { Pygoscelis } \\
\text { papua }\end{array}$ & 05/12/2007 & Ilha Elefante/Antártica & negativo \\
\hline $26 / 07$ & pinguim-papua & $\begin{array}{c}\text { Pygoscelis } \\
\text { papua }\end{array}$ & $05 / 12 / 2007$ & Ilha Elefante/Antártica & negativo \\
\hline $29 / 07$ & $\begin{array}{l}\text { pinguim- } \\
\text { antártico }\end{array}$ & $\begin{array}{l}\text { Pygoscelis } \\
\text { antarctica }\end{array}$ & $05 / 12 / 2007$ & Ilha Elefante/Antártica & negativo \\
\hline $33 / 07$ & $\begin{array}{l}\text { pinguim- } \\
\text { antártico }\end{array}$ & $\begin{array}{l}\text { Pygoscelis } \\
\text { antarctica }\end{array}$ & $05 / 12 / 2007$ & Ilha Elefante/Antártica & negativo \\
\hline $34 / 07$ & $\begin{array}{l}\text { pinguim- } \\
\text { antártico }\end{array}$ & $\begin{array}{l}\text { Pygoscelis } \\
\text { antarctica }\end{array}$ & $05 / 12 / 2007$ & Ilha Elefante/Antártica & negativo \\
\hline $36 / 07$ & $\begin{array}{l}\text { pinguim- } \\
\text { antártico }\end{array}$ & $\begin{array}{l}\text { Pygoscelis } \\
\text { antarctica }\end{array}$ & $05 / 12 / 2007$ & Ilha Elefante/Antártica & negativo \\
\hline $43 / 07$ & pinguim-papua & $\begin{array}{c}\text { Pygoscelis } \\
\text { papua }\end{array}$ & $05 / 12 / 2007$ & Ilha Elefante/Antártica & negativo \\
\hline $49 / 07$ & $\begin{array}{l}\text { pinguim- } \\
\text { antártico }\end{array}$ & $\begin{array}{l}\text { Pygoscelis } \\
\text { antarctica }\end{array}$ & 05/12/2007 & Ilha Elefante/Antártica & negativo \\
\hline $52 / 07$ & $\begin{array}{l}\text { pinguim- } \\
\text { antártico }\end{array}$ & $\begin{array}{l}\text { Pygoscelis } \\
\text { antarctica }\end{array}$ & $05 / 12 / 2007$ & Ilha Elefante/Antártica & negativo \\
\hline $54 / 07$ & $\begin{array}{l}\text { pinguim- } \\
\text { antártico }\end{array}$ & $\begin{array}{l}\text { Pygoscelis } \\
\text { antarctica }\end{array}$ & $05 / 12 / 2007$ & Ilha Elefante/Antártica & negativo \\
\hline $55 / 07$ & $\begin{array}{l}\text { pinguim- } \\
\text { antártico }\end{array}$ & $\begin{array}{l}\text { Pygoscelis } \\
\text { antarctica }\end{array}$ & 05/12/2007 & Ilha Elefante/Antártica & negativo \\
\hline $59 / 07$ & $\begin{array}{l}\text { pinguim- } \\
\text { antártico }\end{array}$ & $\begin{array}{l}\text { Pygoscelis } \\
\text { antarctica }\end{array}$ & 05/12/2007 & Ilha Elefante/Antártica & negativo \\
\hline $60 / 07$ & $\begin{array}{l}\text { pinguim- } \\
\text { antártico }\end{array}$ & $\begin{array}{l}\text { Pygoscelis } \\
\text { antarctica }\end{array}$ & 05/12/2007 & Ilha Elefante/Antártica & negativo \\
\hline $61 / 07$ & $\begin{array}{l}\text { pinguim- } \\
\text { antártico }\end{array}$ & $\begin{array}{l}\text { Pygoscelis } \\
\text { antarctica }\end{array}$ & $06 / 12 / 2007$ & Ilha Elefante/Antártica & negativo \\
\hline $63 / 07$ & $\begin{array}{l}\text { pinguim- } \\
\text { antártico }\end{array}$ & $\begin{array}{l}\text { Pygoscelis } \\
\text { antarctica }\end{array}$ & $06 / 12 / 2007$ & Ilha Elefante/Antártica & negativo \\
\hline
\end{tabular}


(conclusão)

\begin{tabular}{|c|c|c|c|c|c|}
\hline $\begin{array}{c}\text { Identificação } \\
\text { da amostra }\end{array}$ & Nome popular & Nome científico & $\begin{array}{c}\text { Data da } \\
\text { coleta }\end{array}$ & Local & Resultados \\
\hline $67 / 07$ & $\begin{array}{l}\text { pinguim- } \\
\text { antártico }\end{array}$ & $\begin{array}{l}\text { Pygoscelis } \\
\text { antarctica }\end{array}$ & $06 / 12 / 2007$ & Ilha Elefante/Antártica & negativo \\
\hline $68 / 07$ & $\begin{array}{l}\text { pinguim- } \\
\text { antártico }\end{array}$ & $\begin{array}{l}\text { Pygoscelis } \\
\text { antarctica }\end{array}$ & $06 / 12 / 2007$ & Ilha Elefante/Antártica & negativo \\
\hline $69 / 07$ & $\begin{array}{l}\text { pinguim- } \\
\text { antártico }\end{array}$ & $\begin{array}{l}\text { Pygoscelis } \\
\text { antarctica }\end{array}$ & $06 / 12 / 2007$ & Ilha Elefante/Antártica & negativo \\
\hline $83 / 07$ & pinguim-papua & $\begin{array}{l}\text { Pygoscelis } \\
\text { papua }\end{array}$ & 08/12/2007 & Ilha Elefante/Antártica & negativo \\
\hline $88 / 07$ & $\begin{array}{l}\text { pinguim- } \\
\text { antártico }\end{array}$ & $\begin{array}{l}\text { Pygoscelis } \\
\text { antarctica }\end{array}$ & 08/12/2007 & Ilha Elefante/Antártica & negativo \\
\hline $97 / 07$ & pinguim-rei & $\begin{array}{l}\text { Aptenodytes } \\
\text { patagonicus }\end{array}$ & 08/12/2007 & Ilha Elefante/Antártica & negativo \\
\hline $98 / 07$ & pinguim-rei & $\begin{array}{l}\text { Aptenodytes } \\
\text { patagonicus }\end{array}$ & 08/12/2007 & Ilha Elefante/Antártica & negativo \\
\hline $12 / 08$ & $\begin{array}{l}\text { pinguim- } \\
\text { antártico }\end{array}$ & $\begin{array}{l}\text { Pygoscelis } \\
\text { antarctica }\end{array}$ & 03/12/2008 & Frente EACF & negativo \\
\hline $26 / 08$ & pinguim-adélia & $\begin{array}{l}\text { Pygoscelis } \\
\text { adeliae }\end{array}$ & $05 / 12 / 2008$ & Punta Plaza & negativo \\
\hline $27 / 08$ & pinguim-adélia & $\begin{array}{l}\text { Pygoscelis } \\
\text { adeliae }\end{array}$ & 05/12/2008 & Punta Plaza & negativo \\
\hline $49 / 08$ & pinguim-adélia & $\begin{array}{c}\text { Pygoscelis } \\
\text { adeliae }\end{array}$ & $09 / 12 / 2008$ & Frente EACF & negativo \\
\hline $55 / 08$ & pinguim-adélia & $\begin{array}{l}\text { Pygoscelis } \\
\text { adeliae }\end{array}$ & $10 / 12 / 2008$ & Frente EACF & negativo \\
\hline $58 / 08$ & pinguim-adélia & $\begin{array}{l}\text { Pygoscelis } \\
\text { adeliae }\end{array}$ & $10 / 12 / 2008$ & Frente EACF & negativo \\
\hline $65 / 08$ & $\begin{array}{l}\text { pinguim- } \\
\text { antártico }\end{array}$ & $\begin{array}{l}\text { Pygoscelis } \\
\text { antarctica }\end{array}$ & $11 / 12 / 2008$ & Frente EACF & negativo \\
\hline $72 / 08$ & pinguim-adélia & $\begin{array}{l}\text { Pygoscelis } \\
\text { adeliae }\end{array}$ & $12 / 12 / 2008$ & Punta Plaza & negativo \\
\hline $80 / 08$ & $\begin{array}{l}\text { pinguim- } \\
\text { antártico }\end{array}$ & $\begin{array}{l}\text { Pygoscelis } \\
\text { antarctica }\end{array}$ & 09/03/2009 & Punta Plaza-Refúgio 1 & negativo \\
\hline $149 / 08$ & pinguim-papua & $\begin{array}{l}\text { Pygoscelis } \\
\text { рариа }\end{array}$ & $17 / 03 / 2009$ & Módulo de Química & negativo \\
\hline
\end{tabular}


Gel de Agarose - Placa 1 - 10 de novembro de 2009

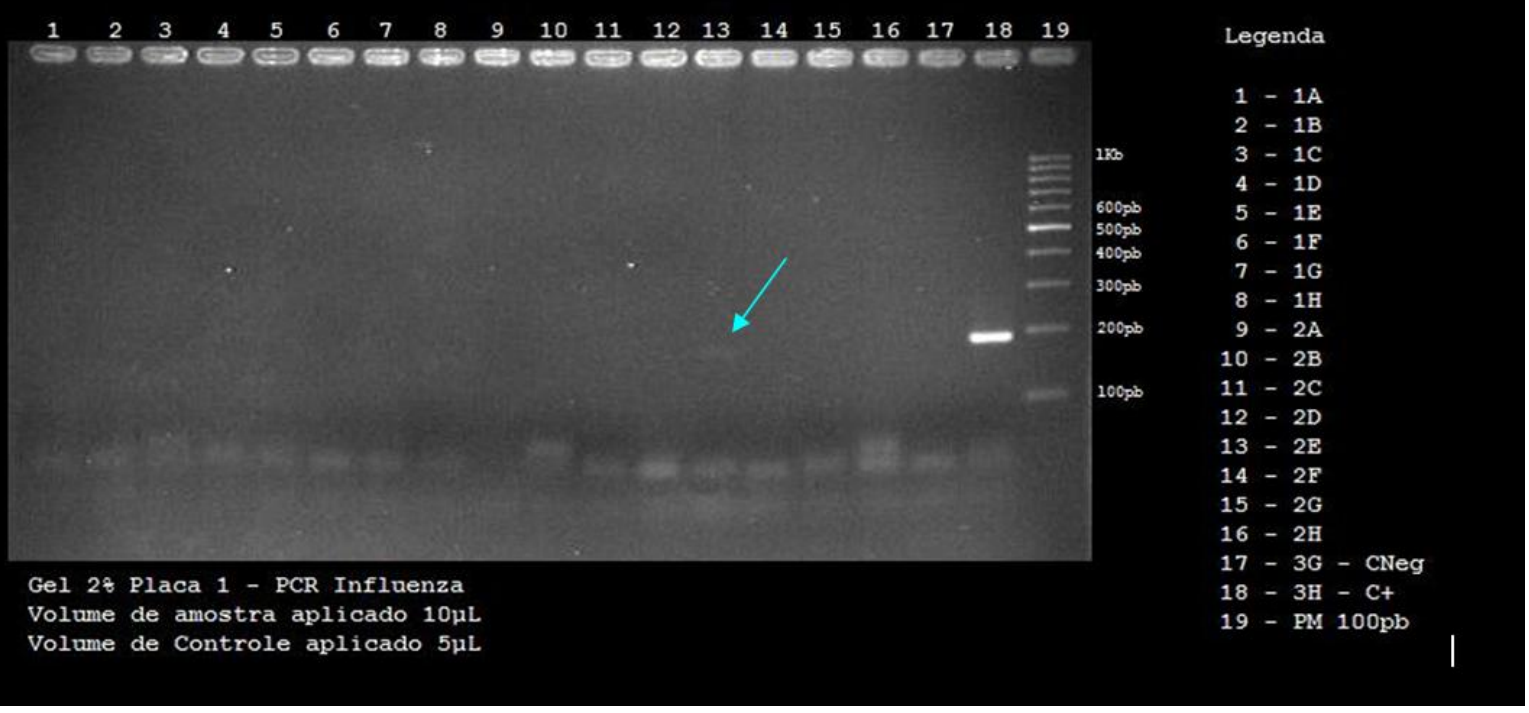

Figura 33 - Resultado positivo do RT - PCR com leitura em gel de agarose (amostra 16/06 de Pygoscelis adeliae).

\subsection{Detecção Viral Através do PCR em Tempo Real}

Foram realizadas reações de PCR em Tempo Real, como descrito, para as amostras consideradas positivas nas reações de PCR e para as 35 amostras que apresentaram uma banda fraca na análise dos géis da RT - PCR. Foi confirmada através deste método a positividade para o vírus da influenza tipo A em oito amostras, estas positivas também para o método de RT - PCR (amostras 16/06, 21/06, 23/06, 42/06, 45/06, 50/06.77/06 e 86/06). As demais 35 amostras testadas com a utilização desta metodologia foram consideradas negativas. 


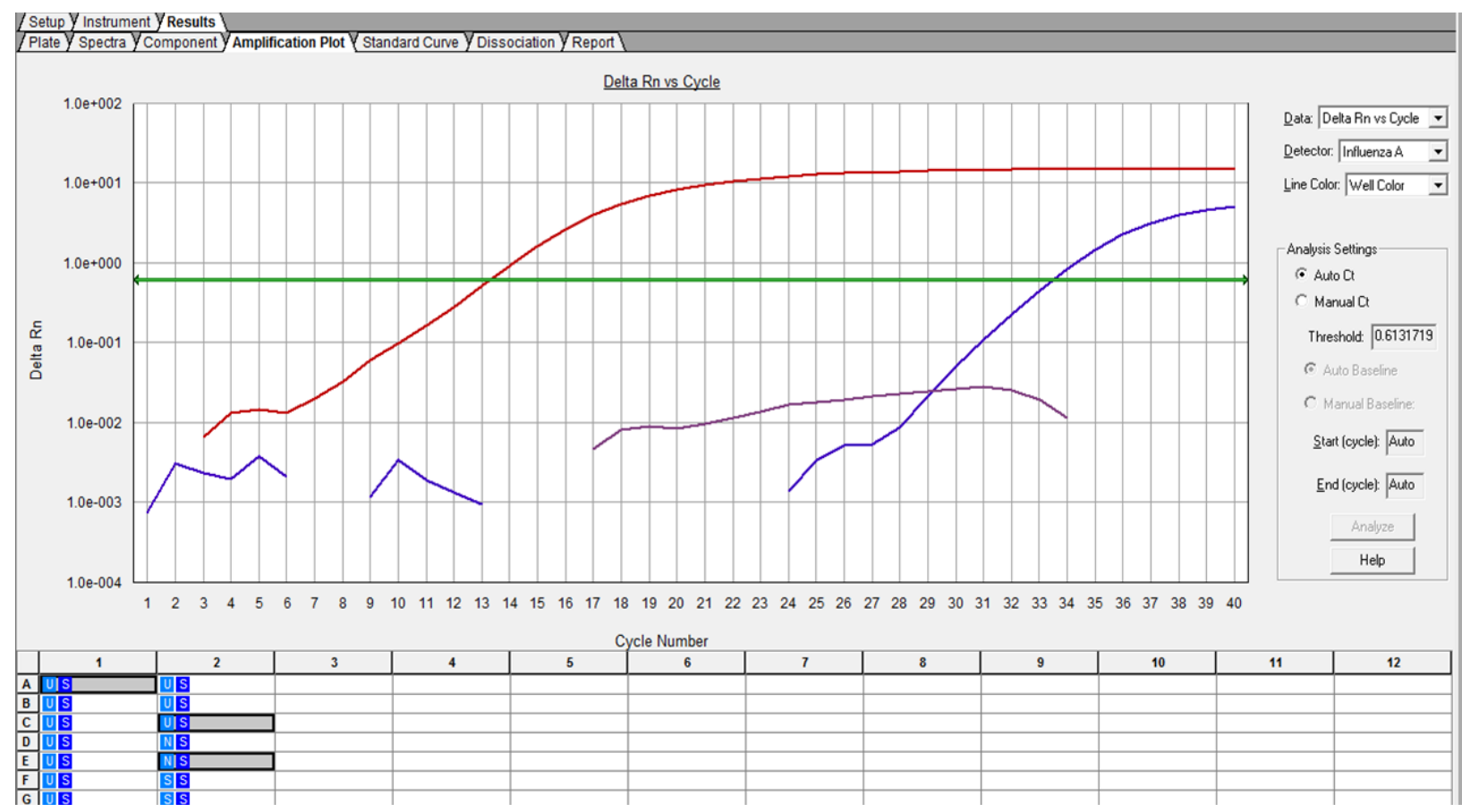

Figura 34 - Resultado do PCR em Tempo Real da amostra 86/06, demonstrando em vermelho a curva de amplificação do controle positivo e em azul a curva de amplificação da amostra.

\subsection{Detecção Viral Através de Técnica de GeneScan}

Foram realizadas reações de PCR com indicador marcado para a detecção viral por GeneScan, utilizando-se da metodologia descrita. As amostras testadas foram as de número 16/06, 21/06, 23/06, 42/06, 45/06, 50/06.77/06 e 86/06. As oito amostras mostraram- se positivas para o vírus da influenza A. Como no caso descrito para o PCR em tempo Real as 35 amostras que apresentaram uma banda fraca na análise dos géis da RT - PCR foram também testadas com a utilização desta metodologia. Nenhuma das 35 amostras testadas apresentou resultado positivo. 


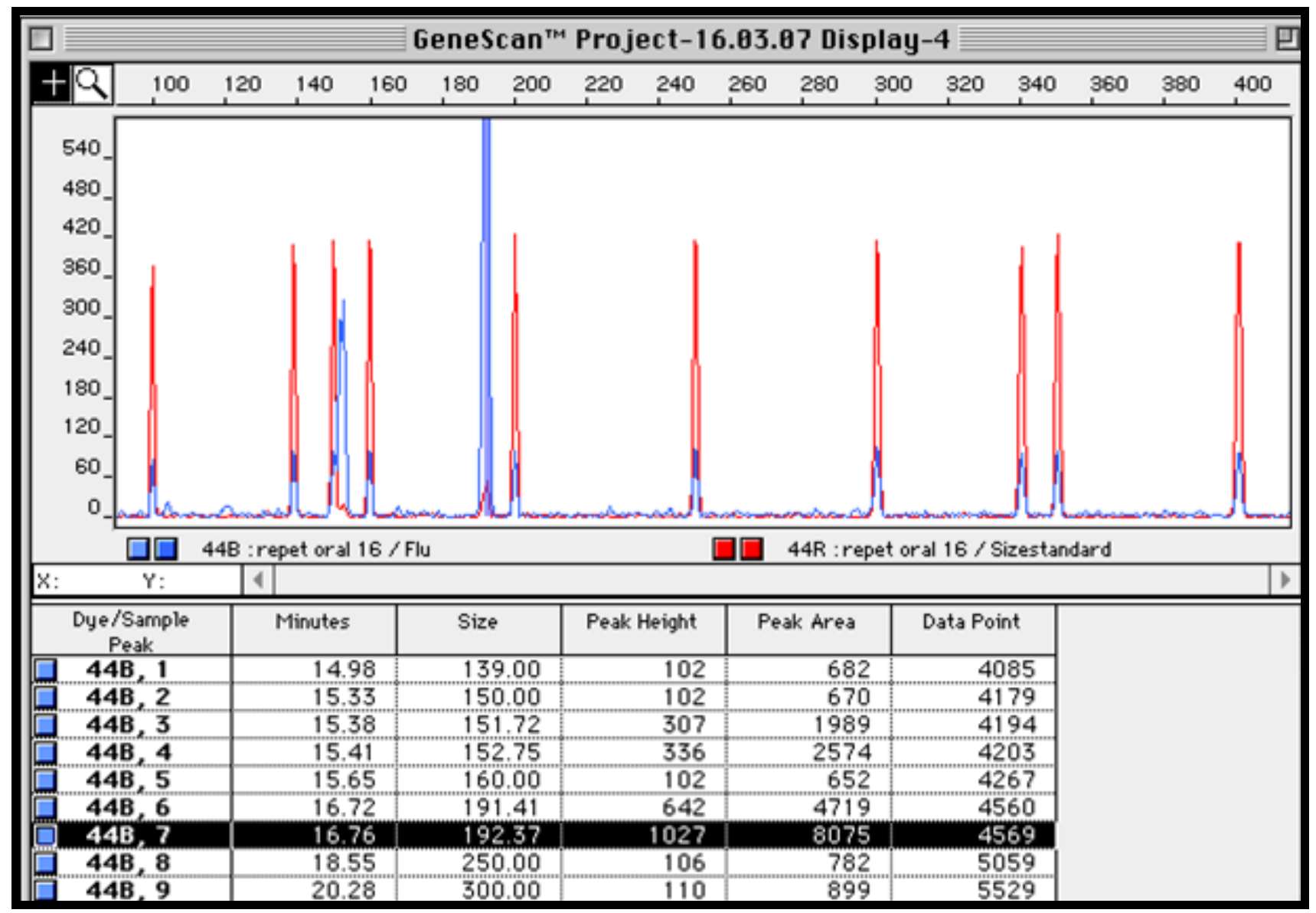

Figura 35 - Resultado do PCR GeneScan da amostra 16/06, demonstrando em vermelho a curva de amplificação do controle positivo e em azul a curva de amplificação da amostra.

\subsection{Sequenciamento}

Procedeu-se o sequenciamento das amostras constatadas como positivas através pelos métodos de PCR com leitura em gel de agarose, PCR em Tempo Real e GeneScan. Das oito amostras testadas somente quatro puderam ser sequenciadas. São elas as amostras 16/06, 21/06, 23/06 e 86/06.

Para a comparação das seqüências das amostras foi realizado o alinhamento destas sequências de nucleotídeos (nt) com as de um controle positivo para o vírus da influenza A H1N1 (Figura 36) visando a a confirmação de sua similaridade.

Com o auxilio do programa Bio Edit Sequence Alignement Editor, também foi possível criar uma tabela que mostra a porcentagem de identidade entre todas as sequências (Tabela 8) 


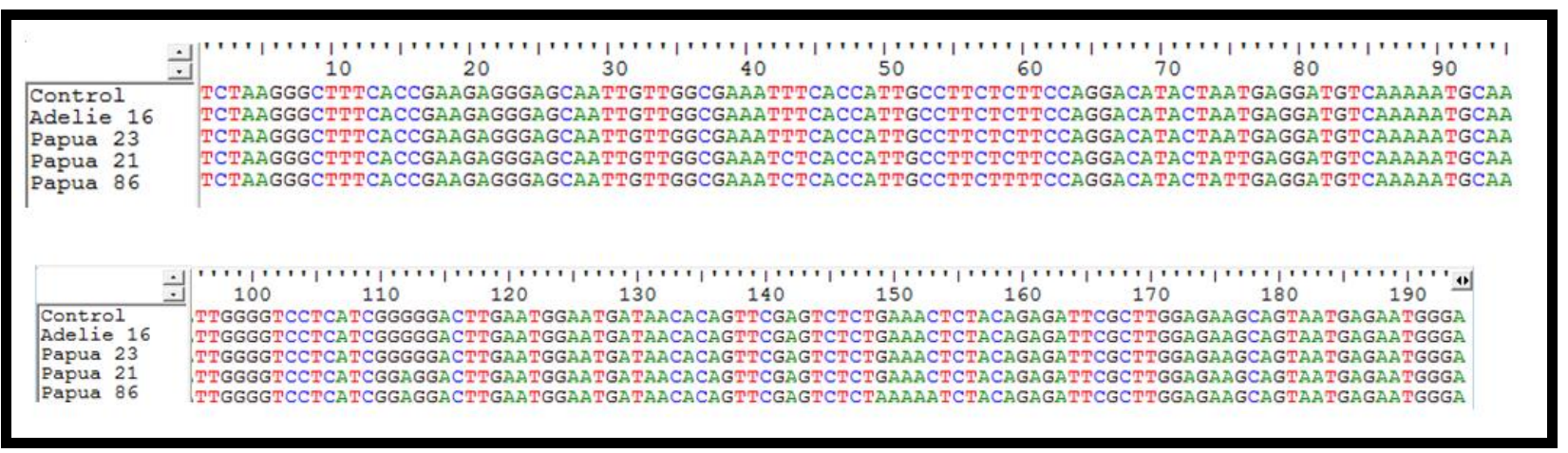

Figura 36 - Comparação entre as sequências de nucleotídeos indicam uma similaridade entre as sequências obtidas e as do controle.

Tabela 8 - Matriz comparativa da identidade verificada entre as amostras positivas para influenza A e o controle positivo H1N1.

\begin{tabular}{lccccc}
\hline & Control H1N1 & Adeliae 16 & Papua 23 & Papua 21 & Papua 86 \\
\hline Control H1N1 & ID & 1 & 1 & 0,984 & 0,968 \\
\hline Adeliae 16 & 1 & ID & 1 & 0,984 & 0,968 \\
\hline Papua 23 & 1 & 1 & ID & 0,984 & 0,968 \\
\hline Papua 21 & 0,984 & 0,984 & 0,984 & ID & 0,984 \\
\hline Papua 86 & 0,968 & 0,968 & 0,968 & 0,984 & ID \\
\hline
\end{tabular}

\subsubsection{Analise genealógica}

Através da análise do fragmento de 192 nucleotídeos do gene codificador para a nucleoproteína NS sequenciado das amostras 16/06, 21/06, 23/06 e 86/06 e comparada com sequencias obtidas no GenBank para o mesmo segmento, obteve-se uma árvore de máxima verossimilhança (maximum likelihood) como pode ser visualizada na Figura 37.

Foram escolhidas sequências do segmento 8 do vírus da influenza A no GenBank de todas as variações possíveis entre a hemaglutinina e a neuraminidase, tendo sido selecionadas 465 sequencias de vírus que infectaram aves porcos e seres humanos em vários continentes. Para a formação da árvore foram retiradas as sequencias de menor similaridade 


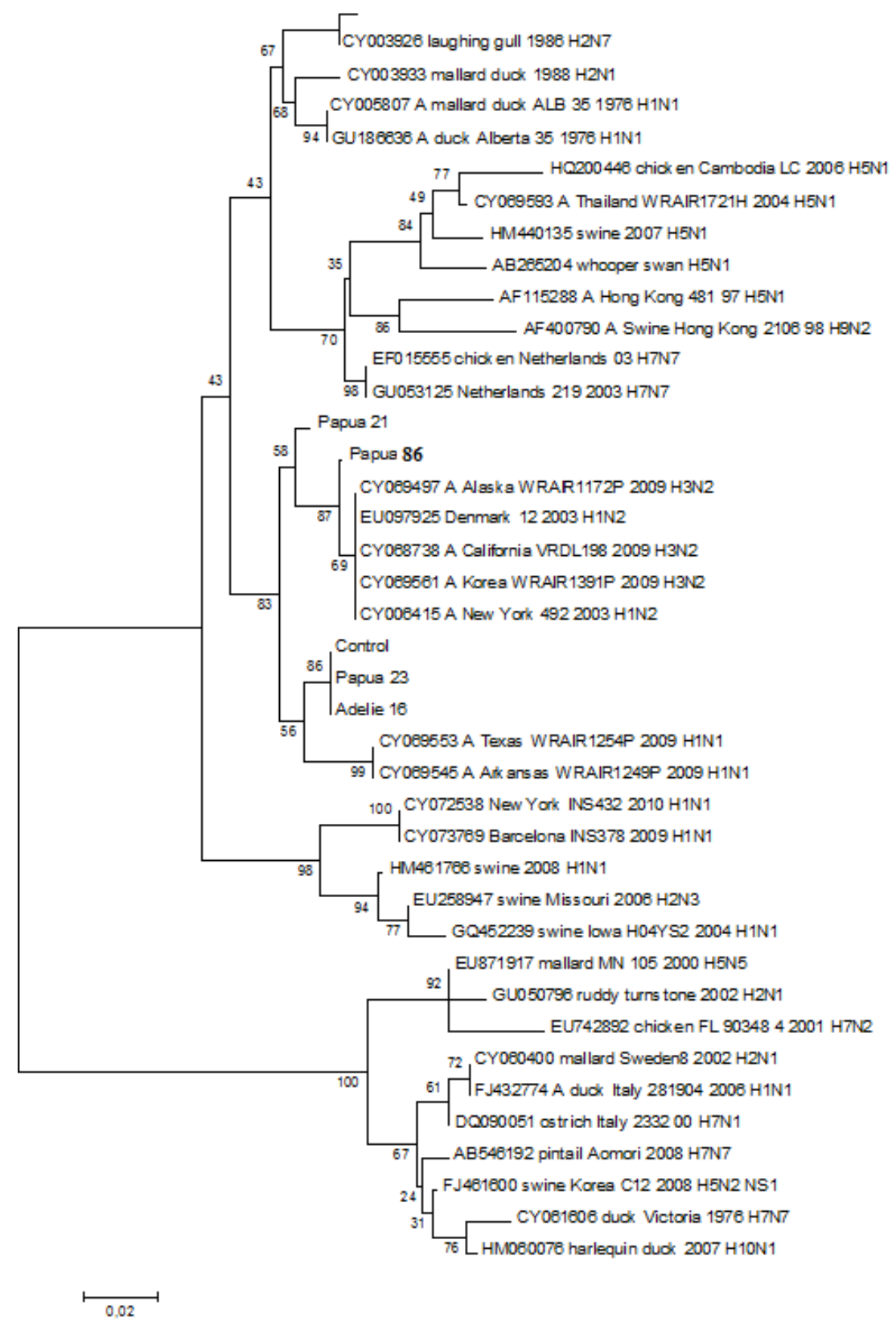

Figura 37 - Árvore filogenética de máxima verossimilhança (maximum likelihood), para nucleoproteína NS construída pelo programa MEGA 4.0 e realizada por uma busca heurística (heuristic search) com o algorítmo "Neighborn joining". Para verificar a sustentação de ramos nas topologias das árvores obtidas, análises de bootstrap com 1000 réplicas. 


\subsection{Inoculação em Ovos Embrionados.}

\subsubsection{Teste de esterilidade}

Todos os testes de esterilidades realizados para as 283 amostras de pinguins foram negativos, ou seja, nenhum contaminante foi detectado nos cultivados em ovos embrionados.

\subsubsection{Teste de hemaglutinação}

No teste de hemaglutinação realizado 6 amostras foram testadas em cada lado da placa. Como resultado constatou-se que o segundo cultivar (segundo ovo) da amostra 31 (pinguim papua coletada próximo ao módulo de química em 2006) matou o embrião. A amostra 35 (pinguim - papua coletada próximo ao módulo de química em 2006) aglutinou as hemácias de galinha. As demais amostras formaram um aglomerado de hemácias no fundo das cavidades.

Com a exceção do cultivado da amostra 35, todas as outras 282 amostras cultivadas foram negativas, tanto na primeira passagem quanto na segunda passagem em ovos embrionados

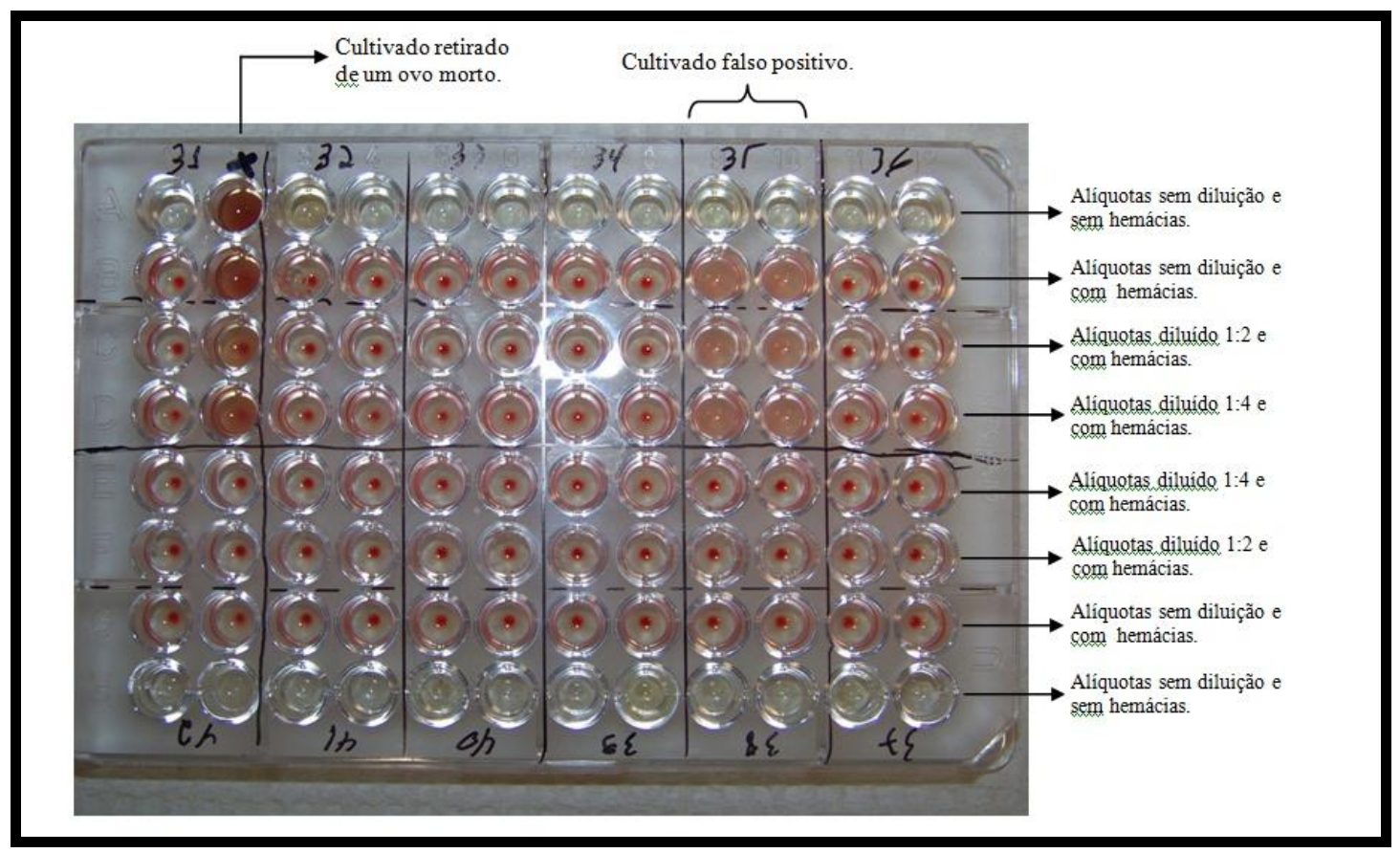

Figura 38 - Resultados obtidos em uma das placas realizadas para o teste de hemaglutinação. 


\subsubsection{Teste rápido para detecção de influenza}

O teste rápido para amostra 35 foi negativo indicando que a aglutinação de hemácias constatada pelo teste de hemaglutinação se tratava de um falso positivo. Além disso, as reações de PCR feitas com essa amostra também foram negativas. A origem do aglutinador de hemácias na placa de titulação permanece não identificada. O teste rápido foi executado duas vezes, sendo, a amostra 35 negativa para ambas tentativas.

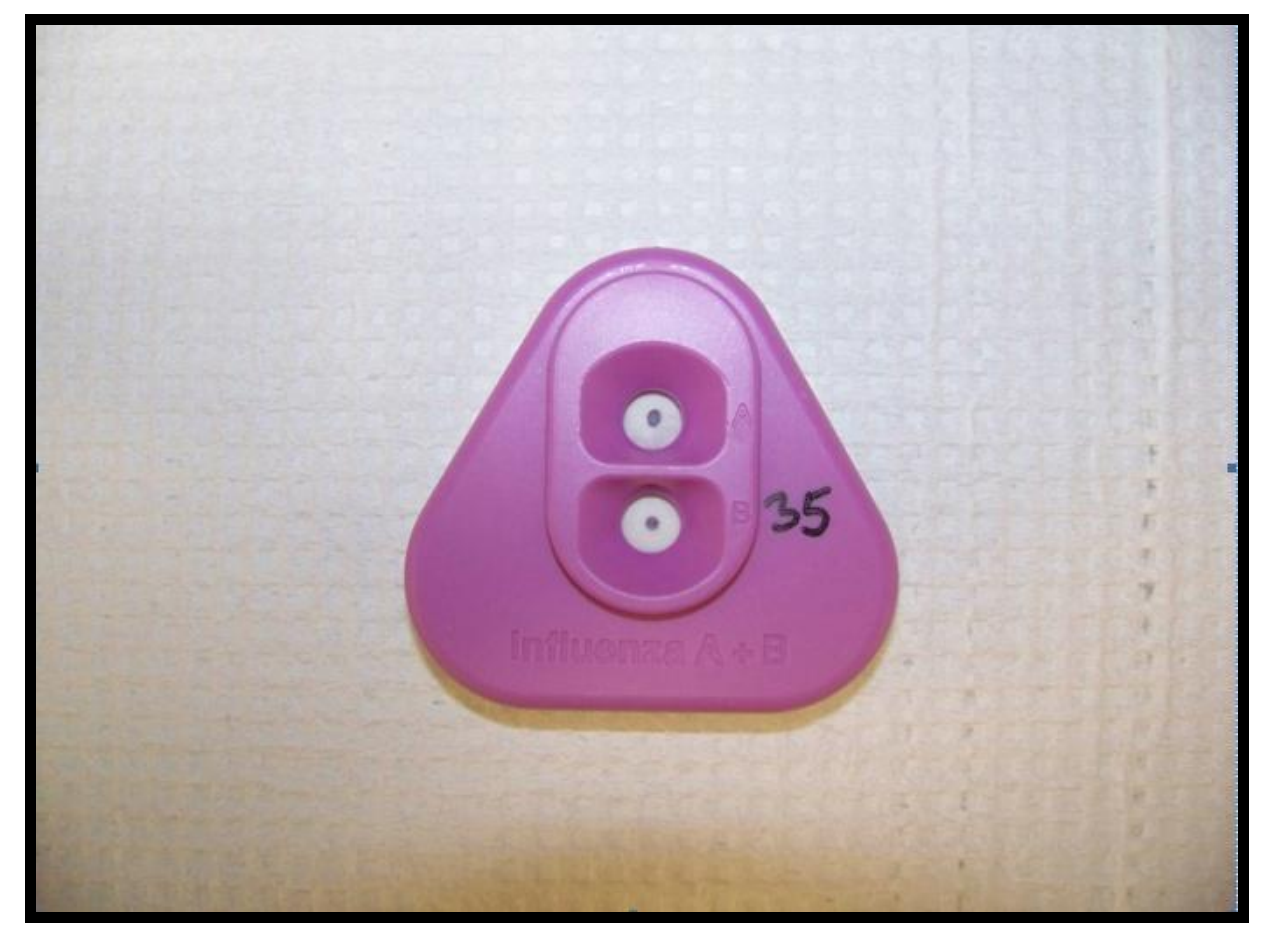

Figura 39 - Teste rápido para a amostra 35. Para ser positiva, deveria aparece na primeira cavidade o desenho de um triângulo. Neste caso, a amostra 35 foi negativa para este teste. 


\section{DISCUSSÃO}

A metodologia utilizada visou principalmente a coleta da maior quantidade possível de amostras de pinguins que tivessem como área de vida a região antártica. As espécies do gênero Pygoscelis foram escolhidas principalmente por formarem grandes colônias e por terem seu deslocamento circunscrito à região antártica e subantártica, não migrando nem estabelecendo populações fora dessas.

A estratégia de escolha de localidades próximas a ninhais de pinguins foi tomada como base para determinação dos pontos de coleta, pois nesses locais as aves estão em maior concentração, proporcionando assim uma maior facilidade de captura.

A área da Estação Brasileira Comandante Ferraz, explorada nos verões antárticos de 2006-2007 e 2008-2009, foi escolhida por estar situada nas proximidades de duas grandes colônias de pinguins. Uma localizada no entorno da Base Polonesa de Arctowski (sítio de especial interesse científico -SSSI 8-, abrigando colônias reprodutivas de pinguins do gênero Pygoscelis) e a outra o refúgio norte - americano Copacabana, onde está localizada uma grande pinguineira com casais de $P$. papua e $P$. adeliae. A proximidade desses dois sítios faz com que as praias na região da estação brasileira sejam sempre visitadas por casais ou indivíduos isolados que descansam entre um forrageamento e outro.

A escolha da ilha Elefante durante o verão de 2007-2008, como terceiro ponto, baseia-se no fato de que nesta localidade se formam grandes colônias de pinguins das três espécies do gênero Pygoscelis.

Dificuldades e limitações da coleta foram encontradas pela própria logística e permissões envolvidas. Na Antártica todo o trabalho de campo está totalmente limitado a algumas condicionantes, tais como, a logística de transporte fornecida pelo Programa Antártico Brasileiro juntamente com a Marinha do Brasil, as condições climáticas e as cotas de captura e manejo de animais para este tipo de pesquisa com as particularidades que devem ser respeitadas devido à época de reprodução.

A logística de transporte envolve as facilidades utilizadas para o deslocamento entre os sítios de coleta onde foram utilizados vários equipamentos com esta finalidade, tais como quadriciclos, botes infláveis e helicóptero.

$\mathrm{Na}$ Antártica as condições climáticas podem limitar as saídas a campo. Todos os dias as condições meteorológicas tem de ser consultadas antes do início dos trabalhos, sendo que a 
captura, manejo e coleta de material das aves em dias de ventos fortes ou nevascas é totalmente vetada por conta do risco envolvido.

Devido à fragilidade das populações de animais que habitam o continente antártico, alguns cuidados foram estabelecidos internacionalmente para sua preservação. O Comitê Especial para Pesquisas Antarticas somente libera a permissão de captura e manejo para retirada de amostras de 100 aves por expedição, sendo que a captura deve ser realizada fora dos sítios onde estão localizados os ninhos, visando interferências mínimas na reprodução das espécies envolvidas.

A metodologia de coleta permitiu, ainda assim, uma amostragem de um considerável número de aves, com a coleta de material de 283 pinguins pertencentes a quatro espécies diferentes. A escolha de localidades distintas proporcionou um equilíbrio numérico bastante razoável de três das espécies estudadas. Foram colhidas amostras de 91 pinguins - papua, 85 pinguins-antártico e 105 pinguins-adélia (32\%, 30\% e 37\% respectivamente).

A exceção foi a captura de apenas dois exemplares de pinguins - rei, espécie esta que também tem sua área de vida circunscrita a região sub - antártica, sendo desta forma interessante para o desenvolvimento deste estudo. Este fato pode ser explicado pela distribuição dessa espécie. A região onde foi desenvolvido o estudo fica no limite norte da área de vida dos pinguins-rei, portanto raramente estas aves se deslocam até lá (Bost et al., 1997).

No trabalho de campo realizado, coletamos amostras traqueais e cloacais com a utilização de zaragatoas. Este tipo de amostragem é importante uma vez que o vírus da influenza tem sua replicação realizada nos tecidos traqueais e intestinais das aves podendo ser disperso no ambiente através de regurgito e fezes. As amostras traqueais geralmente são menos contaminadas favorecendo sempre a extração de RNA e o isolamento do vírus. Nas amostras cloacais pode-se esperar uma maior contaminação, no entanto são amostras que em aves portadoras do vírus da influenza apresentam uma carga viral muito maior.

Uma alíquota de sangue foi também coletada e seu soro retirado ainda em campo. O objetivo dessa coleta foi a identificação do contato das aves com o patógeno, caso os métodos moleculares aplicados nas amostras cloacais/traqueais não viessem a resultar na detecção do vírus. Através da sorologia poder-se-ia identificar quais os subtipos virais envolvidos no contágio com a utilização de técnicas de inibição de hemaglutinação. Os soros não foram utilizados para o presente trabalho. 
Mesmo sem apresentarem qualquer sinal clínico de influenza, 8 dos 283 pinguins amostrados $(2,8 \%)$ apresentaram resultados positivos comprovados pelos métodos de RT - PCR com leitura em gel de agarose e GeneScan através da detecção de um segmento de 192 pares de bases, bastante conservado nos vírus de influenza, encontrado no segmento 8 codificador das proteínas NS.

A confirmação foi realizada através do PCR em Tempo Real onde foram utilizados outros primers que permitiram a detecção de um segmento conservado de 106 pares de bases pertencente ao segmento 7 codificador das proteínas de matriz M1 e M2.

As espécies envolvidas nos achados foram o pinguim-adélia (Pygoscelis adeliae) e o pinguim-papua (Pygoscelis papua). Os três indivíduos do pinguim-adélia e cinco do pinguimpapua com amostras positivas para o vírus da influenza A foram coletados durante o verão antártico de 2006-2007 nas praias próximas a Estação Antártica Brasileira Comandante Ferraz.

Mais 35 amostras testadas pelo método da RT - PCR com leitura em gel de agarose apresentaram possíveis resultados positivos, porém exibindo bandas pouco nítidas, o que poderia estar ligado ao fato de uma baixa carga viral ter sido identificada. Esse fato obrigou a realização de uma nova bateria de testes para a confirmação.

Foram utilizados também para confirmação do vírus de influenza nestas amostras as técnicas de GeneScan e o PCR em Tempo Real. Kubista (2006) descreveu que com a tecnologia da PCR em Tempo Real, a eficiência dos reagentes utilizados na detecção, instrumentação bastante sensível e reações otimizadas, esta metodologia permite a detecção em uma amostra que contenha um número muito baixo de moléculas do material genético, apresentando uma acurácia sem precedentes. Mesmo com a utilização dessa técnica não pode ser evidenciada a presença do vírus nessas 35 amostras, sendo então consideradas negativas.

Interessante ressaltar que todas as amostras positivas foram coletadas durante o verão de 2006-2007. Nesta ocasião devido ao acesso que a equipe de campo obteve a um laboratório situado no Módulo de Química, a extração do material genético foi realizada nos tempos livres entre as coletas de campo. Já para as amostras dos verões e 2007-2008 e 2008-2009 esta estratégia não pode ser repetida por falta de condições na Ilha Elefante e por indisponibilidade de laboratórios na estação brasileira. As amostras coletadas nestes períodos foram então armazenadas em nitrogênio líquido e demoraram alguns meses para chegar ao Brasil para o seu processamento. Durante a viagem de navio o cilindro de nitrogênio ficou armazenado na câmara 
fria e foi reabastecido pela tripulação quando necessário. A impossibilidade do transporte por via aérea e a logística complicada no armazenamento das amostras no navio podem ter sido um complicador para o sucesso na detecção do vírus da influenza, já que 35 amostras apresentaram algum sinal de banda no RT - PCR podendo significar uma baixa carga viral ou uma degradação do material genético contido.

Das 8 amostras positivas obtidas pelo método da RT - PCR quatro puderam ser sequenciadas e comparadas com sequencias do vírus da influenza A.

O sequenciamento foi determinante para a constatação da presença do vírus de influenza A nas amostras de número 16/06, 21/06, 23/06 e 86/06. As amostras 42/06, 45/06, 50,06 e 77/06 apresentaram bandas geradas no gel de agarose mais fracas (dados não mostrados) evidenciando provavelmente uma menor carga viral. Esse fato possivelmente foi o causador da inviabilidade da realização do sequenciamento dessas amostras.

Quando as sequências produzidas foram alinhadas, algumas pequenas variações na posição dos nucleotídeos puderam ser percebidas. Conforme pode ser observado na figura 34, na posição 43 as amostras 21/06 e 86/06 apresentam uma citosina no lugar da timina das demais amostras e do controle. Na posição 59 a amostra 86/06 apresenta uma timina no lugar da citosina das demais amostras e controle positivo. Outra alteração constatada está presente na posição 112 onde se percebe uma substituição da guanina presente no controle positivo e nas outras amostras pela adenina nas amostras 21/06 e 86/06. Por último pode-se observar uma alteração na posição 149 onde se encontra uma adenina na amostra 86/06 no lugar da guanina das demais amostras e controle e na posição 153 onde na mesma amostra 86/06 uma adenina esta no lugar da citosina presente nas demais amostras e controle.

Todas as variações de nucleotídeos encontradas provavelmente foram resultados de mutações de transição com exceção da localizada na posição 153 na amostras 86/06 que apresenta uma mutação de transversão.

Com o alinhamento das sequências de nucleotídeos, pode-se obter uma identidade de $100 \%$ entre o controle H1N1 e as amostras número 16/06 ( $P$. adeliae) e 23/06 (P. papua). Já as amostras 21/06 (P. рариа) e 86/06 (Р. рариа) demonstraram uma identidade de 98,4\% e 96,8\% quando comparadas ao controle e as outras duas outras amostras. O controle positivo obteve uma identidade de $100 \%$ quando comparado com padrões de sequência do gene NS para influenza A do GenBank (192 pb). 
As sequencias obtidas também foram comparadas com padrões depositados no GenBank para o segmento 8 do vírus da influenza A. Para tal foi realizado primeiramente um alinhamento das sequências 16/06, 21/06, 23/06 e 86/06.com 465 sequencias obtidas no banco de dados para todas as variantes recombinantes de HA e NA possíveis encontradas até o momento que tenham infectado aves, porcos, humanos, outros mamíferos ou que foram coletadas no meio ambiente.

Após as análises genealógicas, que foram realizadas empregando os critérios de distâncias evolutivas utilizando o programa MEGA 4.0, formou-se uma árvore de máxima verossimilhança (maximum likelihood) com as 469 sequências. As sequencias que apresentaram uma menor similaridade foram retiradas até a formação da árvore demonstrada na Figura 37.

Apesar da região estudada de 192 pares de base ser altamente conservada para o todos os vírus da influenza A e estar inserida no segmento 8 que codifica as proteínas não estruturais NS1 e NS2, pode-se observar uma similaridade entre a sequência encontrada nos vírus de pinguins e sequências do GenBank de vírus que infectaram seres humanos. As sequencias de vírus que infectaram aves e porcos não obtiveram uma grande similaridade quando comparadas com as amostras de pinguins sequenciadas em nosso estudo. Outro dado interessante diz respeito às sequencias das amostras 16/06 e 23/06 que apresentam maior similaridade com amostras de vírus que acometeram humanos tipificadas como $\mathrm{H} 1 \mathrm{~N} 1$ e as amostras 21/06 e 86/06 tiveram maior similaridade com sequencias de vírus em humanos tipificadas com H2N1 e H3N2.

Foi realizada a tentativa de isolamento de todas as amostras através da passagem em ovos embrionados de galinha. Com a exceção do cultivado da amostra 35, todas as outras 282 amostras cultivadas tiveram resultado negativo, tanto na primeira passagem quanto na segunda passagem em ovos embrionados. O teste de HA realizado para testar a atividade hemaglutinante dos fluidos do líquido alantóico para as 282 amostras cultivadas resultou na precipitação das hemácias. Somente na amostra 35 pertencente a um pinguim - papua coletado próximo ao módulo de química em 2006 pode-se constatar a aglutinação das hemácias de galinha.

Foi então realizado um teste rápido para a identificação do vírus da influenza nessa amostra, porém este resultou negativo. Cabe ressaltar que esta amostra foi considerada negativa para todos os testes moleculares realizados.

Desta forma não foi possível o isolamento do vírus da influenza do tipo A nas 283 amostras de pinguins antárticos. Outros autores já haviam descrito a dificuldade de se isolar cepas 
virais de amostras clínicas de aves adultas e saudáveis, especialmente as linhagens de baixa virulência (Sakai, 2006).

Merece atenção o ineditismo do nosso achado, pois até o momento a comprovação da existência da circulação de vírus da influenza A nas populações de aves na Antártica foi efetivada apenas por de dados sorológicos.

Morgan e Westbury (1981) coletaram amostras de sangue e cloaca de 285 pinguins-adélia nas proximidades da Estação Francesa Dumont d'Urville. Foram realizados testes de HA e tentativa de isolamento do vírus da influenza A em ovos embrionados. Das 285 amostras coletadas somente seis $(2 \%)$ apresentaram anticorpos para $\mathrm{H} 7$, não tendo sido obtido o isolamento do vírus.

Em um estudo realizado por Austin e Webster (1993) na ilha de Ross foram amostrados 91 pinguins-adélia e 60 skuas (Stercorarius maccormicki). Nesses estudos a presença de anticorpos para $\mathrm{H} 10$ em pinguins-adélia foi de 26,3\% e em skua foi de aproximadamente $6 \%$.

Recentemente Wallensten et al (2006b) coletaram 76 amostras e sangue dos pinguinspapua nas ilhas Geórgia do Sul e Ilha dos Pássaros além de 29 amostras de fezes de pinguinsantártico, 30 de pinguins-adélia e 131 de pinguins-papua. Das amostras de sangue testadas 9 $(11,8 \%)$ obtiveram resultados positivos para sorologia de influenza A. As amostras de fezes foram testadas através da utilização da RT - PCR , todas com resultado negativo.

A quantidade de 8 amostras positivas, num total de 283 amostras testadas encontradas no nosso estudo não pode ser considerada um número baixo. Um trabalho de monitoramento de vírus da influenza em aves na grande maioria aquáticas, incluindo pinguins-de-magalhães, realizado na Patagônia Argentina mostra resultados onde o percentual de amostras positivas é de 0,41\%. De um total de 2865 amostras testadas, os autores conseguiram através de métodos moleculares 12 amostras positivas, desse total apenas 1 foi isolada em ovos embrionados (Pereda et al., 2008). Apesar da existência comprovada do vírus da influenza em aves silvestres, principalmente de hábitos aquáticos, na America, a prevalência entre os indivíduos de uma mesma comunidade parece ser baixa.

Uma possível explicação para uma maior prevalência da circulação dos vírus em pinguins antárticos poderia estar ligada aos hábitos dessas aves que formam colônias podendo exceder 100 mil casais na época de procriação. Essa característica é bastante peculiar para as espécies de pinguins antárticos, sendo que as colônias de espécies subtropicais têm geralmente um número 
menor de casais. $\mathrm{O}$ contato constante entre os indivíduos durante a procriação, a disputa por espaço e a proteção dos filhotes, podem estar favorecendo a transmissão do vírus.

A constatação da presença do vírus da influenza A em pinguins na Antártica nos faz pensar como ocorre a circulação deste vírus pelas populações de aves e mamíferos aquáticos que ali habitam e nos visitantes deste continente, como é o caso do homem.

A Antártica não é um continente tão remoto em relação a circulação de patógenos como pode parecer a primeira vista. Algumas espécies de aves que ali vivem são migratórias alcançando as zonas temperadas do planeta durante o inverno antártico, como é o caso dos procelarídeos, larídeos e phalacrocoracídeos. O maior migrante para região antártica que se tem notícia é a andorinha-do-artico (Sterna paradiseae) que nidifica na região do ártico e passa a estação não reprodutiva na região antártica. Estudos realizados com algumas destas espécies comprovam a circulação do vírus da influenza A (Sinnecker et al., 1983).

O contato destas aves migratórias como os petréis, albatrozes, gaivotas e skuas com os pinguins se dá principalmente durante a época reprodutiva quando é possível encontrar tais espécies nidificando perto de colônias de pinguins. Neste período é frequentemente observada também a visita de skuas e gaivotas nas pinguineiras, agindo como predadores oportunistas dos ovos e filhotes de pinguins.

Outro fator importante que deve ser considerado na disseminação de patógenos na região Antártica é a expansão da atividade humana, tanto turística quanto científica.

Embora a Antártica não tenha populações humanas residindo permanentemente, alguns governos mantêm estações de pesquisa instaladas por todo o continente. A população de cientistas no continente e nas ilhas subantárticas varia de aproximadamente quatro mil pessoas no verão a mil no inverno. Muitas das estações de pesquisa mantêm pessoal durante todo o ano.

Apesar do turismo na Antártica ser ainda muito caro, devido a infra-estrutura necessária, nos últimos anos várias agências de turismo se aventuram na região antártica. No momento mais de 10 países diferentes possuem agências atuando na Antártica com navios de turismo. As visitas se concentram nas zonas livres de gelo nos meses entre novembro e março. Os visitantes fazem curtas incursões nas regiões costeiras, visitando estações científicas, monumentos históricos e principalmente as colônias de animais. São explorados ao todo mais de 150 sítios, incluindo 20 estações científicas, nos roteiros das visitas. Alguns sítios recebem até 7000 visitantes 
anualmente. Na década de 80 o número de turistas que frequentava a Antártica não passava de 1000, porém com a recente expansão do turismo atualmente passam dos 45000.

Dessa forma a disseminação do vírus da influenza poderia se dar em dois sentidos. As pessoas podem atuar como vetores, tanto trazendo novas variantes do vírus exóticas para a região como translocando variantes endógenas. Além disso, o estresse causado pela atividade humana crescente pode reduzir a imunidade dos pinguins e outras aves que ali habitam, aumentando a patogenicidade do vírus e a susceptibilidade das aves para a infecção.

Os estudos do vírus de influenza em pinguins antárticos ainda são escassos, mas já demonstram claramente a circulação do vírus nessas populações de aves, tanto através de dados sorológicos quanto por meio da detecção através de metodologia molecular. Porém, pouco é conhecido a respeito da patogenicidade desses vírus, de qual o papel na mortalidade dos pinguins antárticos, quais outras espécies podem estar envolvidas em sua transmissão ou ainda se é possível os pinguins transmitirem as variantes que ai circulam para outras espécies animais ou até para o homem. 


\section{CONCLUSÃO}

Com base nos resultados obtidos podemos concluir:

1 - Que a metodologia de coleta e de análise empregada foi adequada, uma vez que foi detectado o vírus de Influenza A pela primeira vez em pinguins na Antártica. As técnicas moleculares, em especial o RT - PCR, mostraram-se bastante sensíveis mesmo com baixa carga viral. As técnicas de Gene Scan e PCR em Tempo Real mostraram-se tão eficientes quanto a da RT - PCR, servindo para comprovar os resultados desta última.

2 - Que existe influenza aviária na Antártica, provavelmente de baixa patogenicidade ou coevoluida com as aves que habitam este continente. Devido a isto a vigilância epidemiológica deve ser realizada continuamente com a finalidade de detectar possíveis focos futuros, principalmente de vírus de alta patogenicidade.

3 - Que as espécies de aves migratórias que frequentam o continente antártico e entram em contato com aves residentes devem ser constantemente monitoradas para conhecimento da disseminação de variantes virais deste continente para as zonas temperadas e tropicais do planeta e vice versa.

4 - Que com o aumento do contato de seres humanos com animais residentes no continente antártico e região subantártica (devido ao aumento das estações de pesquisa e turismo), linhas de pesquisa devem ser implementadas para o monitoramento das variantes do vírus da influenza, que possam ser carreadas pelo homem a este continente bem como as variantes circulantes nos animais antárticos que possam afetar o ser humano e se dispersar pelo resto do planeta.. 


\section{REFERÊNCIAS*}

Alexander DJ. A review of avian influenza in diferent bird species Vet. Microbiol. 2000;74(1/2):3-13.

Austin FJ, Webster RG.Evidence of Ortho-and Paramyxoviruses in fauna from Antartica. Journal of Wildlife Disease. 1993;29(4)368-371.

Berchieri Jr A, Macari M. Doenças das Aves. Campinas: FACTA - Fundação APINCO de Ciências e Tecnologia Avícolas; 2000.

Besselaar TG, Botha L, McAnerney JM, Schoub BD. Antigenic and molecular analysis of influenza A (H3N2) virus strains isolated from a localised influenza outbreak in South Africa in 2003. J Med Virol. 2004;73(1):71-78.

Boere GC, Stroud DA. The flyway concept: what it is and what it isn't. In: Boere GC, Galbraith CA, Stroud DA, editors. Waterbirds around the world. Edinburgh, UK: The Stationary Office; 2006. p. 40-47. Disponível em:

http://www.jncc.gov.uk/PDF/pub07_waterbirds_part1_flywayconcept.pdf [2008 Out 29].

Bost CA, Georges JY, Guinet C, Cherel Y, Pütz K, Charrassin J B , Handrich Y, Zorn T, Lage J, Maho Y. Foraging habitat and food intake of satellite-tracked king penguins during the austral summer at Crozet Archipelago Marine Ecology Process Series. 1997;150:21-33.

Braakman I, Anken E. Folding of viral envelope glycoproteins in the endoplasmic reticulum, Traffic. 2000;1:533-539.

Bridges CB, Kuehnert MJ, Hall CB. Transmission of influenza: implications for control in health care settings. Clin Infect Dis. 2003;37(8):1094-1101.

Brown EG. Influenza vírus genetics. Biomed Pharmacother. 2000;54(4):196-209.

Büchen-Osmomd C. Ortomyxoviridae. In:__. ICTVdB - The universal Virus Database, version 3. ICTVdB Management. New York, USA: Columbia University; 2003.

Calisher CH. Swine Flu. Croat Med J. 2009;50(4):412-415.

Capua I, Alexander DJ. Avian influenza and human health. Acta Tro. 2002;83(1):1-6.

Capua I, Alexander DJ. Avian influenza: recent developments. Avian Pattho. 2004;4:393-404.

Choi YK; Goyal SM; Kang SW; Farnham MW; Joo HS. Detection and subtyping of swine influenza H1N1, H1N2 and H3N2 viruses in clinical samples using two multiplex RT-PCR assays. J Virol. 2002;102:53-59.

* De acordo com : International Committee of Medical Journal Editors. Uniform requirementsfor manuscripts submitted to Biomedical Journal: sample references. Avaiable from: http://www.icmje.org[2007May22]. 
Claas ECJ, Sprenger MJW, Kleter GEM, VanBeeek R, Quint WGV, Masurel N. Type-specifica indentification of influenza viruses $\mathrm{A}, \mathrm{B}$ and $\mathrm{C}$ by the polymerase chain reaction. J Virol Methods. 1992;39:1-13.

Cherian T, Bobo L, Steinhoff MC, Karron RA, Yolken RH. Use of PCR-enzyme immunoassay for identification of influenza A virus matrix RNA in clinical samples negative for cultivable virus. J Clin Microbiol. 1994;32:623-628.

Cox NJ., Subbarao K. Global epidemiology of influenza: past and present. Annu Rev Med. 2000;51:407-421.

Ellis JS, Fleming DM, Zambon MC. Multiplex reverse transcription-PCR for surveillance of influenza A and B viruses in England and Wales in 1995 and 1996. J Clin Microbiol, 1997;35:2076-2082.

Felsenstein J. Confidence limits on phylogenies: An approach using the bootstrap. Evolution.1985;39:783-791

Fouchier RA, Munster V, Wallensten A, Bestebroer TM, Herfst S, Smith D, Rimmelzwaan GF, Olsen B, Osterhaus ADME. Characterization of a novel influenza a virus hemaglutinin subtype (H16) obtained from Black-headed gulls. J Virol. 2005;79(5):2814-2822.

Gammelin M, Altmuller A, Reinhardt U, Mandler J, Harley VR, Hudson PJ, et al. Phylogenetic analysis of nucleoproteins suggests that human influenza A viruses emerged from a 19th-century avian ancestor. Mol Biol Evol. 1990;(7):194-200.

Geraci, J R, St. Aubin DJ, Barker IK, Webster RG, Hinshaw VS, Bean WJ, Ruhnke HL, Prescott JH, Early G, Baker AS, Madoff S, Schooley RT. Mass mortality of harbor seals: pneumonia associated with influenza A virus. Science. 1982;215(4):1129-1131

Goldsby RA, Kindt TJ, Osborne BA. Kuby Immunology. 4th ed. New York, USA: W.H. Freeman and Company; 2000. 670 p.

Gorman OT, Bean WJ, Kawaoka Y, Webster RG. Evolution of the nucleoprotein gene of influenza A virus. J Virol.1990;(64):1487-97.

Harmon MW. Influenza viruses. In: Lenette, EH, editor. Laboratory Diagnosis of Viral Infections. 2nd ed. New York: Marcel Dekker; 1992. p. 515-534.

Hay AJ. The virus genome and replication. In: Nicholson KG, Webster RG and Hay AJ, editors. Textbook of influenza. London: Blackwell Science; 1998. p. 43-53.

Herrmann B, Larsson C, Zweygberg BW. Simultaneous Detection and Typing of Influenza Viruses A and B by a Nested Reverse Transcription-PCR: Comparison to Virus Isolation and Antigen Detection by Immunofluorescence and Optical Immunoassay (FLU OIA). J Clin Microbiol. 2001;39:134-138. 
Hilleman MR. "Realities and enigmas of human viral influenza: pathogenesis, epidemiology and control. Vaccine. 2002;20:3068-3087.

Hinshaw VS, Bean WJ, Geraci JR, Fiorelli P, Early P, Webster RG . Characterization of two influenza A viruses from a pilot whale. J Virol. 1986;58:655-656.

Honda A, Endo A, Mizumoto K, Ishihama A. Differential roles of viral RNA and cRNA in functional modulation of the influenza virus RNA polymerase. J Bio. Chem.2001,276(33): 31179-31185.

Horimoto T, Rivera E, Pearson J, Senne D, Krauss S, Kawaoka Y, Webster RG. Origin and molecular changes associated with emergence of a highly pathogenic H5N2 influenza virus in Mexico. Virology. 1995;213:223-230

Hunford R. O último lugar da Terra: a competição entre Scott e Amundsen pela conquista do Pólo Sul. São Paulo: Companhia das Letras; 2002.

Izaguirre I, Mataloni G. Antártida, descubriendo el Continente Blanco. S.C. Bariloche, Espana: Ediciones Caleuche; 2000. 24 p.

Kaiser J. A one size fits all flu vaccine. Science. 2006;312:380-382.

Kubista M, Andrade JM, Bengtsson M, Forootan A, Jonák J, Lind K et al. Review: The real-time polymerase chain reaction. Mol Aspec Med. 2006;27:95-125.

Klumpp K, Ruigrok RW, Baudin F. Roles of the influenza vírus polymerase and nucleoprotein in forming a funcional RNA structure. EMBO J. 1997;16(6):1248-1257.

Kuszewski K, Brydak L. The epidemiology and history of influenza. Biomed Pharmacother. 2000;54(4):188-195.

Laver G, Garman E. Pandemic Influenza: its origin and control. Microbes infect. 2002;4(13): 1309-1316.

Mackay IM, Arden KE, Nitshe A, Real-time PCR in virology. Oxford University Press. 2002;30(6):1292-1305.

Mena I, Jambrina E, Albo C, Perales B, Ortin J, Arrese M, Vallejo D, Portela A. Mutational analysis of influenza A virus nucleoprotein: isentification of mutations that affect RNA replications. J Virol. 1999;73(2):1186-1194

Morgan IR, Westbury HA. Virological studies of Adelie Penguins (Pygoscelis adeliae) in Antarctica. Avian Dis. 1981;25(4):1019-26.

Morgan IR, Westbury HA. Studies of viruses in penguins in the Vestfold Hills. Hydrobiologia. 1988;165:263-269. 
Mould JA, Li HC, Dudlak CS, Lear JD, Pekosz A, Lamb RA, Pinto LH. MeccHanism for proton conduction of the M2 ion channel of influenza A virus. J Biol Chem. 2000;275(12):8592-8599.

Murphy BR, Webster RG. Orthomyxovirus. In: Fields BN, Knipe DM, editors. Virology. 2nd ed. New York: Raven Press; 2001.

Nakagawa Y, Oda K, Nakada S. The PB1 subunit alone can catalyze cRNA synthesis, and the PA subunit in addition to the PB1 subunit is required for viral RNA synthesis in replication of the influenza virus genome. J Virol.1996;70(9): 6390-6394.

Nakajima S, Nobusawa E, Nakajima K. Variation in response among individuals to antigenic sites on the HA protein of human influenza virus may be responsible for the emergence of Drift strains in the human population. Virology. 2000;274:220-231.

NCBI ([2010]).[homepage on the Internet]. Scheme of Influenza A virus replication. Modificada de http://www.ncbi.nlm.nih.gov/genomes/GenomesHome [2006 jun08].

National Geographic Society ([2010]). [homepage on the Internet]. Canada. Modificada de http://ngm.nationalgeographic.com/ngm/antarctica/index.html [2008 jun].

Olsen B, Munster VJ, Wallensten A, Waldenstrom J, Osterhaus ADME, Fourchier RAM. Global patterns of influenza A virus in wild birds. Science. 2006;312:384-388.

Pereda AJ, Uhart M, Perez A, Zaccagnini ME, Sala LL, Decarre J, Goijman A, Solari L, Suarez R, Craig MI, Vagnozzi A, Rimondi A, König G, Terrera MV, Kaloghlian A, Song H, Sorrell EM, Perez DR. Avian influenza virus isolated in wild waterfowl in Argentina: Evidence of a potentially unique phylogenetic lineage in South America. Virology. 2008;378:363-370.

Poddar SK. Influenza virus types and subtypes detection by single step single tube multiplex reverse transcription-polymerase chain reaction (RT-PCR) and agarose gel eletrophoresis. J Virol Methods. 2002;99:63-70.

Pontoriero AV, Baumeister EG, Campos AM, Savy VL, Lin YP, Hay A. Antigenic and genomic relation between human influenza viruses that circulated in Argentina in the period 1995-1999 and the corresponding vaccine components. J Clin Virol. 2003;28(2):130-140.

Potter CW. A history of influenza. J Appl Microbiol. 2001;91(4):572-579.

Programa GoogleEarthTM ([2010]). [homepage on the Intenet]. Imagem de satélite mostrando a localização da Estação Brasileira Comandante Ferraz, na Ilha Rei George,. Disponível em http://www.google.com/earth/index.html [2007 dez].

Programa GoogleEarthTM [homepage on the Intenet]. Imagem de satélite mostrando a localização da Ilha Elefante . Disponível em http://www.google.com/earth/index.html [2007 dez]. 
Reina J, Munar M, Blanco I. Evaluation of a direct immunofluorescence assay, dot-blot enzyme immunoassay, and Shell vial culture in diagnosis of lower respiratory tract infections caused by influenza A vírus. Diag Microbiol Infect Dis. 1996;25:143-145.

Sakai K, Yada K, Sakabe G, Tani O, Miyaji K, Nakamura M et al. Serological and Virological Studies of Newcastle Disease and Avian Influenza in Slaughter-Age Ostriches (Struthio camelus) in Japan. J Vet Med Sci. 2006;68(5):491-494.

Sinnecker R, Sinnecker H, Zilske E, e Kphler D. Surveillance of pelagic birds for influenza A viruses. Acta virologica. 1983;27:75-79

Soares PB, Demetrio C, Sanfilippo L., Kawanoto AH, Brentano L, Durigon EL. "Standardization of a duplex RT-PCR for the detection of Influenza A and Newcastle disease viruses in migratory birds. J Virol Methods. 2005;123(2):125-130.

Scientific Committee on Antarctic Research (SCAR) [homepage on the internet]. Available from: http://www.scar.org/treaty/ [2008 Dec 20].

Scholtissek C, Burger H, Bachmann PA, Hannoun C. Genetic relatedness of hemagglutinins of the H1 subtype of influenza A viruses isolated from swine and birds. Virology. 1983;129:521523

Skehel JJ, Wiley DC. Influenza Haemaglutinin.Vaccine. 2002;20(2):51-54.

Smith FB. The Russian Influenza in the United Kingdom, 1889-1894.Social History of Medicine.1995;(8):55-73.

Stockton J, Ellis JS, Saville M, Clewley JP, Zambon MC. Multiplex PCR for typing and subtyping influenza and respiratory syncytial viruses. J Clin Microbiol. 1998;36(10):2990-2925.

Tamura K, Dudley J, Nei M, Kumar S. MEGA4: Molecular Evolutionary Genetics Analysis (MEGA) software version 4.0. Molecular Biology and Evolution. 2007:24:1596-1599.

Taubenberger JK, Reid AH, Janczewski TA, Fanning TG. Integrating historical, clinical and molecular genetic data in order to explain the origin and virulence of the 1918 Spanish influenza virus. Philos Trans R Soc Lond B Biol Sci. 2001;336(1416):1829-1839.

The Center for Food Security \& Public Heath High Pathogenicity Avian Influenza.2010. Disponívelm:http://www.cfsph.iastate.edu/Factsheets/pdfs/highly_pathogenic_avian_influenza.p df. [2010 Set 26]

Van der Vries E, Jonges M, Herfst S, Maaskant J, Van der Linden A, Guldemeester J, Aron GI, Bestebroer TM, Koopmans M, Meijer A, Fouchier RA, Osterhaus AD, Boucher CA, Schutten M. Evaluation of a rapid molecular algorithm for detection of pandemic influenza A (H1N1) 2009 virus and screening for a key oseltamivir resistance $(\mathrm{H} 275 \mathrm{Y})$ substitution in neuraminidase. $\mathbf{J}$ Clin Virol. 2010;47(1):34-7. 
Wallensten A, Munster VJ, Karlsson M, Lundkvist A, Brytting M, Stervander M, et al. High prevalence of influenza A virus in ducks caught during spring migration through Sweden. Vaccine. 2006;24(44-46):6734-5.

Wallensten A, Munster V, Osterhaus AD, Waldenström J, Bonnedahl J, Broman T, et al. Mounting evidence for the presence of influenza A virus in the avifauna of the Antartic region. Antartic Sci. 2006;18:353-6. doi:10.1017/S095410200600040X.

Webster RG. Influenza: An emerging disease. Emerging Infectious Disease. 1998;4:436-441.

Webster RG, Bean WJ, Gorman OT, Chambers TM, Kawaoka Y. Evolution and ecology of influenza A viruses. Microbiol Rev. 1992;56(1):152-179.

Wikipedia([2010]). Mapa da Ilha Elefante[homepage on the Intenet]. Disponível em http://pt.wikipedia.org/wiki/llha_Elefante [2010 set 01].

Wikipedia([2010]). Mapa da Ilha Rei George[homepage on the Intenet]. Disponível em http://pt.wikipedia.org/wiki/Ilha_Rei_George [2010 set 01].

Williams TD. Bird families of the world. The penguins. New York: Oxford University Press; 1995. $295 \mathrm{p}$.

Wright KE, Wilson GA, Novosad D, Kimock C, Tan D, Weber JM. Typing and subtyping of influenza viruses in clinical samples by PCR. J Clin Microbiol. 1995;33(5):1180-1184.

Yewdell J, Garcia-Sastre A. Influenza virus still surprises. Cur Opin Microbiol.2002(5): 414-418.

Zambon MC. Epidemiology and pathogenesis of influenza. J Antimicrob Chemother 1999;44(pt. B):3-9. 
APÊNDICE A - Tabela do resultado do total de amostras testadas pelo método de PCR com visualização em gel de agarose, PCR em Tempo Real, GeneScan e confirmadas por sequenciamento. 
(continua)

\begin{tabular}{|c|c|c|c|c|c|c|}
\hline $\begin{array}{c}\text { Número } \\
\text { de } \\
\text { amostras }\end{array}$ & $\begin{array}{l}\text { Identificação } \\
\text { da Amostra }\end{array}$ & Nome popular & Nome científico & $\begin{array}{c}\text { Data da } \\
\text { coleta }\end{array}$ & Local & Resultados \\
\hline 1. & $01 / 06$ & pinguim-papua & Pygoscelis papua & $20 / 11 / 2006$ & Módulo de Química & Neg. \\
\hline 2. & $02 / 06$ & pinguim-adélia & Pygoscelis adeliae & $20 / 11 / 2006$ & Módulo de Química & Neg. \\
\hline 3. & $03 / 06$ & pinguim-adélia & Pygoscelis adeliae & $20 / 11 / 2006$ & Refúgio 1 & Neg. \\
\hline 4. & 04/06 & pinguim-papua & Pygoscelis papua & $20 / 11 / 2006$ & Refúgio 1 & Neg. \\
\hline 5. & $05 / 06$ & pinguim-papua & Pygoscelis papua & $20 / 11 / 2006$ & Punta Plaza & Neg. \\
\hline 6. & 06/06 & pinguim-adélia & Pygoscelis adeliae & $20 / 11 / 2006$ & Punta Plaza & Neg. \\
\hline 7. & $07 / 06$ & pinguim-adélia & Pygoscelis adeliae & $20 / 11 / 2006$ & Punta Plaza & Neg. \\
\hline 8. & 08/06 & pinguim-adélia & Pygoscelis adeliae & $20 / 11 / 2006$ & Punta Plaza & Neg. \\
\hline 9. & 09/06 & $\begin{array}{l}\text { pinguim- } \\
\text { antártico }\end{array}$ & Pygoscelis antarctica & $20 / 11 / 2006$ & Punta Plaza & Neg. \\
\hline 10. & $10 / 06$ & pinguim-adélia & Pygoscelis adeliae & $20 / 11 / 2006$ & Punta Plaza & Neg. \\
\hline 11. & $11 / 06$ & pinguim-adélia & Pygoscelis adeliae & $21 / 11 / 2006$ & Módulo de Química & Neg. \\
\hline 12. & $12 / 06$ & pinguim-papua & Pygoscelis papua & $21 / 11 / 2006$ & Módulo de Química & Neg. \\
\hline 13. & $13 / 06$ & pinguim-papua & Pygoscelis papua & $21 / 11 / 2006$ & Módulo de Química & Neg. \\
\hline 14. & $14 / 06$ & pinguim-adélia & Pygoscelis adeliae & $21 / 11 / 2006$ & Módulo de Química & Neg. \\
\hline 15. & $15 / 06$ & pinguim-adélia & Pygoscelis adeliae & $21 / 11 / 2006$ & Refúgio 1 & Neg. \\
\hline 16. & $16 / 06$ & pinguim-adélia & Pygoscelis adeliae & $21 / 11 / 2006$ & Refúgio 1 & Pos. \\
\hline 17. & $17 / 06$ & pinguim-adélia & Pygoscelis adeliae & $21 / 11 / 2006$ & Refúgio 1 & Neg. \\
\hline 18. & $18 / 06$ & pinguim-adélia & Pygoscelis adeliae & $21 / 11 / 2006$ & Refúgio 1 & Neg. \\
\hline 19. & 19/06 & pinguim-adélia & Pygoscelis adeliae & $21 / 11 / 2006$ & Refúgio 1 & Neg. \\
\hline 20. & $20 / 06$ & pinguim-adélia & Pygoscelis adeliae & $21 / 11 / 2006$ & Refúgio 1 & Neg. \\
\hline 21. & $21 / 06$ & pinguim-papua & Pygoscelis papua & $21 / 11 / 2006$ & Refúgio 1 & Pos \\
\hline 22. & $22 / 06$ & pinguim-papua & Pygoscelis papиа & $21 / 11 / 2006$ & Refúgio 1 & Neg. \\
\hline 23. & $23 / 06$ & pinguim-papua & Pygoscelis papua & $21 / 11 / 2006$ & Refúgio 1 & Pos \\
\hline 24. & $24 / 06$ & pinguim-adélia & Pygoscelis adeliae & $21 / 11 / 2006$ & Refúgio 1 & Neg. \\
\hline
\end{tabular}


(continuação)

\begin{tabular}{|c|c|c|c|c|c|c|}
\hline $\begin{array}{c}\text { Número } \\
\text { de } \\
\text { amostras }\end{array}$ & $\begin{array}{l}\text { Identificação } \\
\text { da Amostra }\end{array}$ & Nome popular & Nome científico & $\begin{array}{c}\text { Data da } \\
\text { coleta }\end{array}$ & Local & Resultados \\
\hline 25. & $25 / 06$ & pinguim-adélia & Pygoscelis adeliae & $21 / 11 / 2006$ & Refúgio 1 & Neg. \\
\hline 26. & $26 / 06$ & pinguim-adélia & Pygoscelis adeliae & $21 / 11 / 2006$ & Refúgio 1 & Neg. \\
\hline 27. & $27 / 06$ & pinguim-adélia & Pygoscelis adeliae & $21 / 11 / 2006$ & Refúgio 1 & Neg. \\
\hline 28. & $28 / 06$ & pinguim-papua & Pygoscelis papua & $21 / 11 / 2006$ & Refúgio 1 & Neg. \\
\hline 29. & $29 / 06$ & pinguim-papua & Pygoscelis рариа & $21 / 11 / 2006$ & Refúgio 1 & Neg. \\
\hline 30. & $30 / 06$ & pinguim-papua & Pygoscelis papua & $21 / 11 / 2006$ & Refúgio 1 & Neg. \\
\hline 31. & $31 / 06$ & pinguim-papua & Pygoscelis рариа & $21 / 11 / 2006$ & Módulo de Química & Neg. \\
\hline 32. & $32 / 06$ & pinguim-papua & Pygoscelis рариа & $21 / 11 / 2006$ & Módulo de Química & Neg. \\
\hline 33. & $33 / 06$ & pinguim-papua & Pygoscelis papua & $21 / 11 / 2006$ & Módulo de Química & Neg. \\
\hline 34. & $34 / 06$ & pinguim-adélia & Pygoscelis adeliae & $21 / 11 / 2006$ & Módulo de Química & Neg. \\
\hline 35. & $35 / 06$ & pinguim-papua & Pygoscelis papua & $23 / 11 / 2006$ & Punta Hennequin & Neg. \\
\hline 36. & $36 / 06$ & pinguim-adélia & Pygoscelis adeliae & $23 / 11 / 2006$ & Punta Hennequin & Neg. \\
\hline 37. & $37 / 06$ & pinguim-adélia & Pygoscelis adeliae & $23 / 11 / 2006$ & Punta Hennequin & Neg. \\
\hline 38. & $38 / 06$ & pinguim-adélia & Pygoscelis adeliae & $23 / 11 / 2006$ & Punta Hennequin & Neg. \\
\hline 39. & $39 / 06$ & pinguim-adélia & Pygoscelis adeliae & $23 / 11 / 2006$ & Punta Hennequin & Neg. \\
\hline 40. & $40 / 06$ & pinguim-adélia & Pygoscelis adeliae & $23 / 11 / 2006$ & Punta Hennequin & Neg. \\
\hline 41. & $41 / 06$ & pinguim-papua & Pygoscelis рариа & $23 / 11 / 2006$ & Punta Hennequin & Neg. \\
\hline 42. & $42 / 06$ & pinguim-papua & Pygoscelis papиа & $23 / 11 / 2006$ & Punta Hennequin & Pos. \\
\hline 43. & $43 / 06$ & pinguim-papua & Pygoscelis papua & $23 / 11 / 2006$ & Punta Hennequin & Neg. \\
\hline 44. & $44 / 06$ & pinguim-papua & Pygoscelis pариа & $27 / 11 / 2006$ & Módulo de Química & Neg. \\
\hline 45. & $45 / 06$ & pinguim-adélia & Pygoscelis adeliae & $27 / 11 / 2006$ & Módulo de Química & Pos \\
\hline 46. & $46 / 06$ & pinguim-adélia & Pygoscelis adeliae & $27 / 11 / 2006$ & Módulo de Química & Neg. \\
\hline 47. & $47 / 06$ & pinguim-papua & Pygoscelis pариа & $27 / 11 / 2006$ & Módulo de Química & Neg. \\
\hline 48. & $48 / 06$ & pinguim-adélia & Pygoscelis adeliae & $27 / 11 / 2006$ & Módulo de Química & Neg. \\
\hline
\end{tabular}


(continuação)

\begin{tabular}{|c|c|c|c|c|c|c|}
\hline $\begin{array}{c}\text { Número } \\
\text { de } \\
\text { amostras }\end{array}$ & $\begin{array}{c}\text { Identificação } \\
\text { da Amostra }\end{array}$ & Nome popular & Nome científico & $\begin{array}{c}\text { Data da } \\
\text { coleta }\end{array}$ & Local & Resultados \\
\hline 49. & $49 / 06$ & pinguim-adélia & Pygoscelis adeliae & $27 / 11 / 2006$ & Módulo de Química & Neg. \\
\hline 50. & $50 / 06$ & pinguim-рариа & Pygoscelis papua & $27 / 11 / 2006$ & Refúgio 1 & Pos. \\
\hline 51. & $51 / 06$ & pinguim-adélia & Pygoscelis adeliae & $27 / 11 / 2006$ & Refúgio 1 & Neg. \\
\hline 52. & $52 / 06$ & pinguim-adélia & Pygoscelis adeliae & $27 / 11 / 2006$ & Refúgio 1 & Neg. \\
\hline 53. & $53 / 06$ & pinguim-adélia & Pygoscelis adeliae & $27 / 11 / 2006$ & Refúgio 1 & Neg. \\
\hline 54. & $54 / 06$ & pinguim-adélia & Pygoscelis adeliae & $27 / 11 / 2006$ & Refúgio 1 & Neg. \\
\hline 55. & $55 / 06$ & pinguim-adélia & Pygoscelis adeliae & $27 / 11 / 2006$ & Refúgio 1 & Neg. \\
\hline 56. & $56 / 06$ & pinguim-adélia & Pygoscelis adeliae & $27 / 11 / 2006$ & Refúgio 1 & Neg. \\
\hline 57. & $57 / 06$ & pinguim-рариа & Pygoscelis papua & $27 / 11 / 2006$ & Refúgio 1 & Neg. \\
\hline 58. & $58 / 06$ & pinguim-adélia & Pygoscelis adeliae & $27 / 11 / 2006$ & Refúgio 1 & Neg. \\
\hline 59. & $59 / 06$ & pinguim-adélia & Pygoscelis adeliae & $27 / 11 / 2006$ & Refúgio 1 & Neg. \\
\hline 60. & $60 / 06$ & pinguim-adélia & Pygoscelis adeliae & $27 / 11 / 2006$ & Refúgio 1 & Neg. \\
\hline 61. & $61 / 06$ & pinguim-adélia & Pygoscelis adeliae & $29 / 11 / 2006$ & Refúgio 1 & Neg. \\
\hline 62. & $62 / 06$ & pinguim-adélia & Pygoscelis adeliae & $29 / 11 / 2006$ & Refúgio 1 & Neg. \\
\hline 63. & $63 / 06$ & pinguim-adélia & Pygoscelis adeliae & $29 / 11 / 2006$ & Módulo de Química & Neg. \\
\hline 64. & $64 / 06$ & pinguim-adélia & Pygoscelis adeliae & $29 / 11 / 2006$ & Refúgio 1 & Neg. \\
\hline 65. & $65 / 06$ & pinguiт-рариа & Pygoscelis papиа & $29 / 11 / 2006$ & Refúgio 1 & Neg. \\
\hline 66. & $66 / 06$ & pinguim-рариа & Pygoscelis papua & $29 / 11 / 2006$ & Refúgio 1 & Neg. \\
\hline 67. & $67 / 06$ & pinguim-рариа & Pygoscelis papua & $29 / 11 / 2006$ & Refúgio 1 & Neg. \\
\hline 68. & $68 / 06$ & pinguim-рариа & Pygoscelis papua & $29 / 11 / 2006$ & Refúgio 1 & Neg. \\
\hline 69. & $69 / 06$ & pinguim-рариа & Pygoscelis papиа & $29 / 11 / 2006$ & Refúgio 1 & Neg. \\
\hline 70. & $70 / 06$ & pinguim-рариа & Pygoscelis papua & $29 / 11 / 2006$ & Refúgio 1 & Neg. \\
\hline 71. & $71 / 06$ & pinguim-antártico & Pygoscelis antarctica & $29 / 11 / 2006$ & Refúgio 1 & Neg. \\
\hline 72. & $72 / 06$ & pinguim-adélia & Pygoscelis adeliae & $29 / 11 / 2006$ & Refúgio 1 & Neg. \\
\hline
\end{tabular}


(continuação)

\begin{tabular}{|c|c|c|c|c|c|c|}
\hline $\begin{array}{l}\text { Número } \\
\text { de } \\
\text { amostras }\end{array}$ & $\begin{array}{c}\text { Identificaçãa } \\
\text { da Amostra }\end{array}$ & Nome popular & Nome científico & $\begin{array}{c}\text { Data da } \\
\text { coleta }\end{array}$ & Local & Resultados \\
\hline 73. & $73 / 06$ & pinguim-antártico & Pygoscelis antarctica & $30 / 11 / 2006$ & $\begin{array}{l}\text { Entre Punta Plaza e o } \\
\text { Módulo de Química }\end{array}$ & Neg. \\
\hline 74. & $74 / 06$ & pinguim-antártico & Pygoscelis antarctica & $30 / 11 / 2006$ & $\begin{array}{l}\text { Entre Punta Plaza e o } \\
\text { Módulo de Química }\end{array}$ & Neg. \\
\hline 75. & $75 / 06$ & pinguim-antártico & Pygoscelis antarctica & $30 / 11 / 2006$ & $\begin{array}{l}\text { Entre Punta Plaza e o } \\
\text { Módulo de Química }\end{array}$ & Neg. \\
\hline 76. & $76 / 06$ & pinguim-adélia & Pygoscelis adeliae & $30 / 11 / 2006$ & $\begin{array}{l}\text { Entre Punta Plaza e o } \\
\text { Módulo de Química }\end{array}$ & Neg. \\
\hline 77. & $77 / 06$ & pinguim-adélia & Pygoscelis adeliae & $30 / 11 / 2006$ & $\begin{array}{l}\text { Entre Punta Plaza e o } \\
\text { Módulo de Química }\end{array}$ & Pos. \\
\hline 78. & $78 / 06$ & pinguim-papua & Pygoscelis papua & $30 / 11 / 2006$ & $\begin{array}{l}\text { Entre Punta Plaza e o } \\
\text { Módulo de Química }\end{array}$ & Neg. \\
\hline 79. & 79/06 & pinguim-antártico & Pygoscelis antarctica & $30 / 11 / 2006$ & $\begin{array}{l}\text { Entre Punta Plaza e o } \\
\text { Módulo de Química }\end{array}$ & Neg. \\
\hline 80. & $80 / 06$ & pinguim-antártico & Pygoscelis antarctica & $30 / 11 / 2006$ & $\begin{array}{l}\text { Entre Punta Plaza e o } \\
\text { Módulo de Química }\end{array}$ & Neg. \\
\hline 81. & $81 / 06$ & pinguim-antártico & Pygoscelis antarctica & $30 / 11 / 2006$ & $\begin{array}{l}\text { Entre Punta Plaza e o } \\
\text { Módulo de Química }\end{array}$ & Neg. \\
\hline 82. & $82 / 06$ & pinguim-adélia & Pygoscelis adeliae & $30 / 11 / 2006$ & $\begin{array}{l}\text { Entre Punta Plaza e o } \\
\text { Módulo de Química }\end{array}$ & Neg. \\
\hline 83. & $83 / 06$ & pinguim-adélia & Pygoscelis adeliae & $30 / 11 / 2006$ & $\begin{array}{l}\text { Entre Punta Plaza e o } \\
\text { Módulo de Química }\end{array}$ & Neg. \\
\hline 84. & $84 / 06$ & pinguim-adélia & Pygoscelis adeliae & $30 / 11 / 2006$ & $\begin{array}{l}\text { Entre Punta Plaza e o } \\
\text { Módulo de Química }\end{array}$ & Neg. \\
\hline 85. & $85 / 06$ & pinguim-рариа & Pygoscelis pариа & $30 / 11 / 2006$ & $\begin{array}{l}\text { Entre Punta Plaza e o } \\
\text { Módulo de Química }\end{array}$ & Neg. \\
\hline 86. & $86 / 06$ & pinguim-papua & Pygoscelis papua & $30 / 11 / 2006$ & $\begin{array}{l}\text { Entre Punta Plaza e o } \\
\text { Módulo de Química }\end{array}$ & Pos \\
\hline 87. & $87 / 06$ & pinguim-adélia & Pygoscelis adeliae & $01 / 12 / 2006$ & $\begin{array}{l}\text { Entre Punta Plaza e o } \\
\text { Módulo de Química }\end{array}$ & Neg. \\
\hline 88. & $88 / 06$ & pinguim-adélia & Pygoscelis adeliae & $01 / 12 / 2006$ & $\begin{array}{l}\text { Entre Punta Plaza e o } \\
\text { Módulo de Química }\end{array}$ & Neg. \\
\hline 89. & $89 / 06$ & pinguim-adélia & Pygoscelis adeliae & $01 / 12 / 2006$ & $\begin{array}{l}\text { Entre Punta Plaza e o } \\
\text { Módulo de Química }\end{array}$ & Neg. \\
\hline 90. & $90 / 06$ & pinguim-adélia & Pygoscelis adeliae & $01 / 12 / 2006$ & $\begin{array}{l}\text { Entre Punta Plaza e o } \\
\text { Módulo de Química }\end{array}$ & Neg. \\
\hline 91. & $91 / 06$ & pinguim-рариа & Pygoscelis рариа & $01 / 12 / 2006$ & $\begin{array}{l}\text { Entre Punta Plaza e o } \\
\text { Módulo de Química }\end{array}$ & Neg. \\
\hline 92. & $92 / 06$ & pinguim-adélia & Pygoscelis adeliae & $01 / 12 / 2006$ & $\begin{array}{l}\text { Entre Punta Plaza e o } \\
\text { Módulo de Química }\end{array}$ & Neg. \\
\hline 93. & $93 / 06$ & pinguim-adélia & Pygoscelis adeliae & $01 / 12 / 2006$ & $\begin{array}{l}\text { Entre Punta Plaza e o } \\
\text { Módulo de Química }\end{array}$ & Neg. \\
\hline 94. & $94 / 06$ & pinguim-papua & Pygoscelis pариа & $01 / 12 / 2006$ & $\begin{array}{l}\text { Entre Punta Plaza e o } \\
\text { Módulo de Química }\end{array}$ & Neg. \\
\hline 95. & 95/06 & pinguim-рариа & Pygoscelis pариа & $01 / 12 / 2006$ & $\begin{array}{l}\text { Entre Punta Plaza e o } \\
\text { Módulo de Química }\end{array}$ & Neg. \\
\hline
\end{tabular}


(continuação)

\begin{tabular}{|c|c|c|c|c|c|c|}
\hline $\begin{array}{c}\text { Número } \\
\text { de } \\
\text { amostras }\end{array}$ & $\begin{array}{l}\text { Identificação } \\
\text { da Amostra }\end{array}$ & Nome popular & Nome científico & $\begin{array}{c}\text { Data da } \\
\text { coleta }\end{array}$ & Local & Resultados \\
\hline 96. & $96 / 06$ & pinguim-adélia & Pygoscelis adeliae & $01 / 12 / 2006$ & $\begin{array}{l}\text { Entre Punta Plaza e o } \\
\text { Módulo de Química }\end{array}$ & Neg. \\
\hline 97. & $97 / 06$ & pinguim-adélia & Pygoscelis adeliae & $06 / 12 / 2006$ & $\begin{array}{l}\text { Entre Punta Plaza e o } \\
\text { Módulo de Química }\end{array}$ & Neg. \\
\hline 98. & $98 / 06$ & pinguim-adélia & Pygoscelis adeliae & $06 / 12 / 2006$ & $\begin{array}{l}\text { Entre Punta Plaza e o } \\
\text { Módulo de Química }\end{array}$ & Neg. \\
\hline 99. & $99 / 06$ & pinguim-adélia & Pygoscelis adeliae & $06 / 12 / 2006$ & $\begin{array}{l}\text { Entre Punta Plaza e o } \\
\text { Módulo de Química }\end{array}$ & Neg. \\
\hline 100. & 100/06 & pinguim-papua & Pygoscelis papиа & $06 / 12 / 2006$ & $\begin{array}{l}\text { Entre Punta Plaza e o } \\
\text { Módulo de Química }\end{array}$ & Neg. \\
\hline 101. & $01 / 07$ & pinguim-antártico & Pygoscelis antarctica & $04 / 12 / 2007$ & $\begin{array}{l}\text { Ilha } \\
\text { Elefante/Antártica }\end{array}$ & Neg. \\
\hline 102. & $02 / 07$ & pinguim-papua & Pygoscelis papиа & $04 / 12 / 2007$ & $\begin{array}{l}\text { Ilha } \\
\text { Elefante/Antártica }\end{array}$ & Neg. \\
\hline 103. & 03/07 & pinguim-papua & Pygoscelis papua & $04 / 12 / 2007$ & $\begin{array}{l}\text { Ilha } \\
\text { Elefante/Antártica }\end{array}$ & Neg. \\
\hline 104. & 04/07 & pinguim-antártico & Pygoscelis antarctica & $04 / 12 / 2007$ & $\begin{array}{l}\text { Ilha } \\
\text { Elefante/Antártica }\end{array}$ & Neg. \\
\hline 105. & $05 / 07$ & pinguim-papua & Pygoscelis papиа & $04 / 12 / 2007$ & $\begin{array}{l}\text { Ilha } \\
\text { Elefante/Antártica }\end{array}$ & Neg. \\
\hline 106. & 06/07 & pinguim-papua & Pygoscelis papua & $04 / 12 / 2007$ & $\begin{array}{l}\text { Ilha } \\
\text { Elefante/Antártica }\end{array}$ & Neg. \\
\hline 107. & $07 / 07$ & pinguim-antártico & Pygoscelis antarctica & $04 / 12 / 2007$ & $\begin{array}{l}\text { Ilha } \\
\text { Elefante/Antártica }\end{array}$ & Neg. \\
\hline 108. & 08/07 & pinguim-papua & Pygoscelis papua & $04 / 12 / 2007$ & $\begin{array}{l}\text { Ilha } \\
\text { Elefante/Antártica }\end{array}$ & Neg. \\
\hline 109. & 09/07 & pinguim-papua & Pygoscelis papиа & $04 / 12 / 2007$ & $\begin{array}{l}\text { Ilha } \\
\text { Elefante/Antártica }\end{array}$ & Neg. \\
\hline 110. & $10 / 07$ & pinguim-antártico & Pygoscelis antarctica & $04 / 12 / 2007$ & $\begin{array}{l}\text { Ilha } \\
\text { Elefante/Antártica }\end{array}$ & Neg. \\
\hline 111. & $11 / 07$ & pinguim-antártico & Pygoscelis antarctica & $04 / 12 / 2007$ & $\begin{array}{l}\text { Ilha } \\
\text { Elefante/Antártica }\end{array}$ & Neg. \\
\hline 112. & $12 / 07$ & pinguim-antártico & Pygoscelis antarctica & $04 / 12 / 2007$ & $\begin{array}{l}\text { Ilha } \\
\text { Elefante/Antártica }\end{array}$ & Neg. \\
\hline 113. & $13 / 07$ & pinguim-antártico & Pygoscelis antarctica & $04 / 12 / 2007$ & $\begin{array}{l}\text { Ilha } \\
\text { Elefante/Antártica }\end{array}$ & Neg \\
\hline 114. & $14 / 07$ & pinguim-antártico & Pygoscelis antarctica & $04 / 12 / 2007$ & $\begin{array}{l}\text { Ilha } \\
\text { Elefante/Antártica }\end{array}$ & Neg. \\
\hline 115. & $15 / 07$ & pinguim-antártico & Pygoscelis antarctica & $04 / 12 / 2007$ & $\begin{array}{l}\text { Ilha } \\
\text { Elefante/Antártica }\end{array}$ & Neg. \\
\hline 116. & $16 / 07$ & pinguim-papua & Pygoscelis papua & $04 / 12 / 2007$ & $\begin{array}{l}\text { Ilha } \\
\text { Elefante/Antártica }\end{array}$ & Neg. \\
\hline 117. & $17 / 07$ & pinguim-papua & Pygoscelis papua & $04 / 12 / 2007$ & $\begin{array}{l}\text { Ilha } \\
\text { Elefante/Antártica }\end{array}$ & Neg. \\
\hline 118. & $18 / 07$ & pinguim-antártico & Pygoscelis antarctica & $04 / 12 / 2007$ & $\begin{array}{l}\text { Ilha } \\
\text { Elefante/Antártica }\end{array}$ & Neg. \\
\hline 119. & $19 / 07$ & pinguim-papua & Pygoscelis papua & $04 / 12 / 2007$ & $\begin{array}{l}\text { Ilha } \\
\text { Elefante/Antártica }\end{array}$ & Neg. \\
\hline
\end{tabular}


(continuação)

\begin{tabular}{|c|c|c|c|c|c|c|}
\hline $\begin{array}{c}\text { Número } \\
\text { de } \\
\text { amostras }\end{array}$ & $\begin{array}{l}\text { Identificação } \\
\text { da Amostra }\end{array}$ & Nome popular & Nome científico & $\begin{array}{c}\text { Data da } \\
\text { coleta }\end{array}$ & Local & Resultados \\
\hline 120. & $20 / 07$ & pinguim-papua & Pygoscelis papua & $04 / 12 / 2007$ & $\begin{array}{l}\text { Ilha } \\
\text { Elefante/Antártica }\end{array}$ & Neg. \\
\hline 121. & $21 / 07$ & pinguim-antártico & Pygoscelis antarctica & $04 / 12 / 2007$ & $\begin{array}{l}\text { Ilha } \\
\text { Elefante/Antártica }\end{array}$ & Neg. \\
\hline 122. & $22 / 07$ & pinguim-papua & Pygoscelis papиа & $04 / 12 / 2007$ & $\begin{array}{l}\text { Ilha } \\
\text { Elefante/Antártica }\end{array}$ & Neg. \\
\hline 123. & $23 / 07$ & pinguim-antártico & Pygoscelis antarctica & $04 / 12 / 2007$ & $\begin{array}{l}\text { Ilha } \\
\text { Elefante/Antártica }\end{array}$ & Neg. \\
\hline 124. & $24 / 07$ & pinguim-papua & Pygoscelis papua & $04 / 12 / 2007$ & $\begin{array}{l}\text { Ilha } \\
\text { Elefante/Antártica }\end{array}$ & Neg. \\
\hline 125. & $25 / 07$ & pinguim-papua & Pygoscelis papua & $05 / 12 / 2007$ & $\begin{array}{l}\text { Ilha } \\
\text { Elefante/Antártica }\end{array}$ & $\mathrm{Neg}$ \\
\hline 126. & $26 / 07$ & pinguim-papua & Pygoscelis papua & $05 / 12 / 2007$ & $\begin{array}{l}\text { Ilha } \\
\text { Elefante/Antártica }\end{array}$ & $\mathrm{Neg}$ \\
\hline 127. & $27 / 07$ & pinguim-papua & Pygoscelis papua & $05 / 12 / 2007$ & $\begin{array}{l}\text { Ilha } \\
\text { Elefante/Antártica }\end{array}$ & Neg. \\
\hline 128. & $28 / 07$ & pinguim-antártico & Pygoscelis antarctica & $05 / 12 / 2007$ & $\begin{array}{l}\text { Ilha } \\
\text { Elefante/Antártica }\end{array}$ & Neg. \\
\hline 129. & $29 / 07$ & pinguim-antártico & Pygoscelis antarctica & $05 / 12 / 2007$ & $\begin{array}{l}\text { Ilha } \\
\text { Elefante/Antártica }\end{array}$ & $\mathrm{Neg}$ \\
\hline 130. & $30 / 07$ & pinguim-papua & Pygoscelis papua & $05 / 12 / 2007$ & $\begin{array}{l}\text { Ilha } \\
\text { Elefante/Antártica }\end{array}$ & Neg. \\
\hline 131. & $31 / 07$ & pinguim-papua & Pygoscelis papua & $05 / 12 / 2007$ & $\begin{array}{l}\text { Ilha } \\
\text { Elefante/Antártica }\end{array}$ & Neg. \\
\hline 132. & $32 / 07$ & pinguim-antártico & Pygoscelis antarctica & $05 / 12 / 2007$ & $\begin{array}{l}\text { Ilha } \\
\text { Elefante/Antártica }\end{array}$ & Neg. \\
\hline 133. & $33 / 07$ & pinguim-antártico & Pygoscelis antarctica & $05 / 12 / 2007$ & $\begin{array}{l}\text { Ilha } \\
\text { Elefante/Antártica }\end{array}$ & Neg \\
\hline 134. & $34 / 07$ & pinguim-antártico & Pygoscelis antarctica & $05 / 12 / 2007$ & $\begin{array}{l}\text { Ilha } \\
\text { Elefante/Antártica }\end{array}$ & $\mathrm{Neg}$ \\
\hline 135. & $35 / 07$ & pinguim-antártico & Pygoscelis antarctica & $05 / 12 / 2007$ & $\begin{array}{l}\text { Ilha } \\
\text { Elefante/Antártica }\end{array}$ & Neg. \\
\hline 136. & $36 / 07$ & pinguim-antártico & Pygoscelis antarctica & $05 / 12 / 2007$ & $\begin{array}{l}\text { Ilha } \\
\text { Elefante/Antártica }\end{array}$ & $\mathrm{Neg}$ \\
\hline 137. & $37 / 07$ & pinguim-papua & Pygoscelis papua & $05 / 12 / 2007$ & $\begin{array}{l}\text { Ilha } \\
\text { Elefante/Antártica }\end{array}$ & Neg. \\
\hline 138. & $38 / 07$ & pinguim-papua & Pygoscelis papua & $05 / 12 / 2007$ & $\begin{array}{l}\text { Ilha } \\
\text { Elefante/Antártica }\end{array}$ & Neg. \\
\hline 139. & $39 / 07$ & pinguim-antártico & Pygoscelis antarctica & $05 / 12 / 2007$ & $\begin{array}{l}\text { Ilha } \\
\text { Elefante/Antártica }\end{array}$ & Neg. \\
\hline 140. & $40 / 07$ & pinguim-antártico & Pygoscelis antarctica & $05 / 12 / 2007$ & $\begin{array}{l}\text { Ilha } \\
\text { Elefante/Antártica }\end{array}$ & Neg. \\
\hline 141. & $41 / 07$ & pinguim-antártico & Pygoscelis antarctica & $05 / 12 / 2007$ & $\begin{array}{l}\text { Ilha } \\
\text { Elefante/Antártica }\end{array}$ & Neg. \\
\hline 142. & $42 / 07$ & pinguim-antártico & Pygoscelis antarctica & $05 / 12 / 2007$ & $\begin{array}{l}\text { Ilha } \\
\text { Elefante/Antártica }\end{array}$ & Neg. \\
\hline 143. & $43 / 07$ & pinguim-papua & Pygoscelis papиа & $05 / 12 / 2007$ & $\begin{array}{l}\text { Ilha } \\
\text { Elefante/Antártica }\end{array}$ & $\mathrm{Neg}$ \\
\hline
\end{tabular}


(continuação)

\begin{tabular}{|c|c|c|c|c|c|c|}
\hline $\begin{array}{c}\begin{array}{c}\text { Número } \\
\text { de } \\
\text { amostras }\end{array} \\
\end{array}$ & $\begin{array}{c}\text { Identificação } \\
\text { da Amostra }\end{array}$ & Nome popular & Nome científico & $\begin{array}{c}\text { Data da } \\
\text { coleta }\end{array}$ & Local & Resultados \\
\hline 144. & $44 / 07$ & pinguim-antártico & Pygoscelis antarctica & $05 / 12 / 2007$ & $\begin{array}{l}\text { Ilha } \\
\text { Elefante/Antártica }\end{array}$ & Neg. \\
\hline 145. & $45 / 07$ & pinguim-antártico & Pygoscelis antarctica & $05 / 12 / 2007$ & $\begin{array}{l}\text { Ilha } \\
\text { Elefante/Antártica }\end{array}$ & Neg. \\
\hline 146. & $46 / 07$ & pinguim-papua & Pygoscelis papua & $05 / 12 / 2007$ & $\begin{array}{l}\text { Ilha } \\
\text { Elefante/Antártica }\end{array}$ & Neg. \\
\hline 147. & $47 / 07$ & pinguim-antártico & Pygoscelis antarctica & $05 / 12 / 2007$ & $\begin{array}{l}\text { Ilha } \\
\text { Elefante/Antártica }\end{array}$ & Neg. \\
\hline 148. & $48 / 07$ & pinguim-papua & Pygoscelis pариа & $05 / 12 / 2007$ & $\begin{array}{l}\text { Ilha } \\
\text { Elefante/Antártica }\end{array}$ & Neg. \\
\hline 149. & $49 / 07$ & pinguim-antártico & Pygoscelis antarctica & $05 / 12 / 2007$ & $\begin{array}{l}\text { Ilha } \\
\text { Elefante/Antártica }\end{array}$ & Neg \\
\hline 150. & $50 / 07$ & pinguim-antártico & Pygoscelis antarctica & $05 / 12 / 2007$ & $\begin{array}{l}\text { Ilha } \\
\text { Elefante/Antártica }\end{array}$ & Neg. \\
\hline 151. & $51 / 07$ & pinguim-antártico & Pygoscelis antarctica & $05 / 12 / 2007$ & $\begin{array}{l}\text { Ilha } \\
\text { Elefante/Antártica }\end{array}$ & Neg. \\
\hline 152. & $52 / 07$ & pinguim-antártico & Pygoscelis antarctica & $05 / 12 / 2007$ & $\begin{array}{l}\text { Ilha } \\
\text { Elefante/Antártica }\end{array}$ & $\mathrm{Neg}$ \\
\hline 153. & $53 / 07$ & pinguim-antártico & Pygoscelis antarctica & $05 / 12 / 2007$ & $\begin{array}{l}\text { Ilha } \\
\text { Elefante/Antártica }\end{array}$ & Neg. \\
\hline 154. & $54 / 07$ & pinguim-antártico & Pygoscelis antarctica & $05 / 12 / 2007$ & $\begin{array}{l}\text { Ilha } \\
\text { Elefante/Antártica }\end{array}$ & Neg \\
\hline 155. & $55 / 07$ & pinguim-antártico & Pygoscelis antarctica & $05 / 12 / 2007$ & $\begin{array}{l}\text { Ilha } \\
\text { Elefante/Antártica }\end{array}$ & Neg \\
\hline 156. & $56 / 07$ & pinguim-antártico & Pygoscelis antarctica & $05 / 12 / 2007$ & $\begin{array}{l}\text { Ilha } \\
\text { Elefante/Antártica }\end{array}$ & Neg. \\
\hline 157. & $57 / 07$ & pinguim-papua & Pygoscelis papиа & $05 / 12 / 2007$ & $\begin{array}{l}\text { Ilha } \\
\text { Elefante/Antártica }\end{array}$ & Neg. \\
\hline 158. & $58 / 07$ & pinguim-antártico & Pygoscelis antarctica & $05 / 12 / 2007$ & $\begin{array}{l}\text { Ilha } \\
\text { Elefante/Antártica }\end{array}$ & Neg. \\
\hline 159. & $59 / 07$ & pinguim-antártico & Pygoscelis antarctica & $05 / 12 / 2007$ & $\begin{array}{l}\text { Ilha } \\
\text { Elefante/Antártica }\end{array}$ & $\mathrm{Neg}$ \\
\hline 160. & $60 / 07$ & pinguim-antártico & Pygoscelis antarctica & $05 / 12 / 2007$ & $\begin{array}{l}\text { Ilha } \\
\text { Elefante/Antártica }\end{array}$ & Neg \\
\hline 161. & $61 / 07$ & pinguim-antártico & Pygoscelis antarctica & $06 / 12 / 2007$ & $\begin{array}{l}\text { Ilha } \\
\text { Elefante/Antártica }\end{array}$ & Neg \\
\hline 162. & $62 / 07$ & pinguim-antártico & Pygoscelis antarctica & $06 / 12 / 2007$ & $\begin{array}{l}\text { Ilha } \\
\text { Elefante/Antártica }\end{array}$ & Neg. \\
\hline 163. & $63 / 07$ & pinguim-antártico & Pygoscelis antarctica & $06 / 12 / 2007$ & $\begin{array}{l}\text { Ilha } \\
\text { Elefante/Antártica }\end{array}$ & $\mathrm{Neg}$ \\
\hline 164. & $64 / 07$ & pinguim-antártico & Pygoscelis antarctica & $06 / 12 / 2007$ & $\begin{array}{l}\text { Ilha } \\
\text { Elefante/Antártica }\end{array}$ & Neg. \\
\hline 165. & $65 / 07$ & pinguim-papua & Pygoscelis рариа & 06/12/2007 & $\begin{array}{l}\text { Ilha } \\
\text { Elefante/Antártica }\end{array}$ & Neg. \\
\hline 166. & $66 / 07$ & pinguim-antártico & Pygoscelis antarctica & $06 / 12 / 2007$ & $\begin{array}{l}\text { Ilha } \\
\text { Elefante/Antártica }\end{array}$ & Neg. \\
\hline 167. & $67 / 07$ & pinguim-antártico & Pygoscelis antarctica & $06 / 12 / 2007$ & $\begin{array}{l}\text { Ilha } \\
\text { Elefante/Antártica }\end{array}$ & Neg \\
\hline
\end{tabular}


(continuação)

\begin{tabular}{|c|c|c|c|c|c|c|}
\hline $\begin{array}{c}\text { Número } \\
\text { de } \\
\text { amostras }\end{array}$ & $\begin{array}{l}\text { Identificação } \\
\text { da Amostra }\end{array}$ & Nome popular & Nome científico & $\begin{array}{c}\text { Data da } \\
\text { coleta }\end{array}$ & Local & Resultados \\
\hline 168. & $68 / 07$ & pinguim-antártico & Pygoscelis antarctica & $06 / 12 / 2007$ & $\begin{array}{l}\text { Ilha } \\
\text { Elefante/Antártica }\end{array}$ & $\mathrm{Neg}$ \\
\hline 169. & $69 / 07$ & pinguim-antártico & Pygoscelis antarctica & $06 / 12 / 2007$ & $\begin{array}{l}\text { Ilha } \\
\text { Elefante/Antártica }\end{array}$ & Neg \\
\hline 170. & $70 / 07$ & pinguim-papua & Pygoscelis papua & $06 / 12 / 2007$ & $\begin{array}{l}\text { Ilha } \\
\text { Elefante/Antártica }\end{array}$ & Neg. \\
\hline 171. & $71 / 07$ & pinguim-papua & Pygoscelis papua & $06 / 12 / 2007$ & $\begin{array}{l}\text { Ilha } \\
\text { Elefante/Antártica }\end{array}$ & Neg. \\
\hline 172. & $72 / 07$ & pinguim-antártico & Pygoscelis antarctica & $06 / 12 / 2007$ & $\begin{array}{l}\text { Ilha } \\
\text { Elefante/Antártica }\end{array}$ & Neg. \\
\hline 173. & $73 / 07$ & pinguim-antártico & Pygoscelis antarctica & $08 / 12 / 2007$ & $\begin{array}{l}\text { Ilha } \\
\text { Elefante/Antártica }\end{array}$ & Neg. \\
\hline 174. & $74 / 07$ & pinguim-papua & Pygoscelis pариа & $08 / 12 / 2007$ & $\begin{array}{l}\text { Ilha } \\
\text { Elefante/Antártica }\end{array}$ & Neg. \\
\hline 175. & $75 / 07$ & pinguim-papua & Pygoscelis papua & $08 / 12 / 2007$ & $\begin{array}{l}\text { Ilha } \\
\text { Elefante/Antártica }\end{array}$ & Neg. \\
\hline 176. & $76 / 07$ & pinguim-antártico & Pygoscelis antarctica & $08 / 12 / 2007$ & $\begin{array}{l}\text { Ilha } \\
\text { Elefante/Antártica }\end{array}$ & Neg. \\
\hline 177. & $77 / 07$ & pinguim-antártico & Pygoscelis antarctica & $08 / 12 / 2007$ & $\begin{array}{l}\text { Ilha } \\
\text { Elefante/Antártica }\end{array}$ & Neg. \\
\hline 178. & $78 / 07$ & pinguim-antártico & Pygoscelis antarctica & $08 / 12 / 2007$ & $\begin{array}{l}\text { Ilha } \\
\text { Elefante/Antártica }\end{array}$ & Neg. \\
\hline 179. & $79 / 07$ & pinguim-papua & Pygoscelis papиа & $08 / 12 / 2007$ & $\begin{array}{l}\text { Ilha } \\
\text { Elefante/Antártica }\end{array}$ & Neg. \\
\hline 180. & $80 / 07$ & pinguim-antártico & Pygoscelis antarctica & $08 / 12 / 2007$ & $\begin{array}{l}\text { Ilha } \\
\text { Elefante/Antártica }\end{array}$ & Neg. \\
\hline 181. & $81 / 07$ & pinguim-antártico & Pygoscelis antarctica & $08 / 12 / 2007$ & $\begin{array}{l}\text { Ilha } \\
\text { Elefante/Antártica }\end{array}$ & Neg. \\
\hline 182. & $82 / 07$ & pinguim-antártico & Pygoscelis antarctica & $08 / 12 / 2007$ & $\begin{array}{l}\text { Ilha } \\
\text { Elefante/Antártica }\end{array}$ & Neg. \\
\hline 183. & $83 / 07$ & pinguim-papua & Pygoscelis papua & $08 / 12 / 2007$ & $\begin{array}{l}\text { Ilha } \\
\text { Elefante/Antártica }\end{array}$ & $\mathrm{Neg}$ \\
\hline 184. & $84 / 07$ & pinguim-antártico & Pygoscelis antarctica & $08 / 12 / 2007$ & $\begin{array}{l}\text { Ilha } \\
\text { Elefante/Antártica }\end{array}$ & Neg. \\
\hline 185. & $85 / 07$ & pinguim-antártico & Pygoscelis antarctica & $08 / 12 / 2007$ & $\begin{array}{l}\text { Ilha } \\
\text { Elefante/Antártica }\end{array}$ & Neg. \\
\hline 186. & $86 / 07$ & pinguim-antártico & Pygoscelis antarctica & $08 / 12 / 2007$ & $\begin{array}{l}\text { Ilha } \\
\text { Elefante/Antártica }\end{array}$ & Neg. \\
\hline 187. & $87 / 07$ & pinguim-antártico & Pygoscelis antarctica & $08 / 12 / 2007$ & $\begin{array}{l}\text { Ilha } \\
\text { Elefante/Antártica }\end{array}$ & Neg. \\
\hline 188. & $88 / 07$ & pinguim-antártico & Pygoscelis antarctica & $08 / 12 / 2007$ & $\begin{array}{l}\text { Ilha } \\
\text { Elefante/Antártica }\end{array}$ & Neg. \\
\hline 189. & $89 / 07$ & pinguim-papua & Pygoscelis papиа & $08 / 12 / 2007$ & $\begin{array}{l}\text { Ilha } \\
\text { Elefante/Antártica }\end{array}$ & Neg. \\
\hline 190. & $90 / 07$ & pinguim-antártico & Pygoscelis antarctica & $08 / 12 / 2007$ & $\begin{array}{l}\text { Ilha } \\
\text { Elefante/Antártica }\end{array}$ & Neg. \\
\hline
\end{tabular}


(continuação)

\begin{tabular}{|c|c|c|c|c|c|c|}
\hline $\begin{array}{c}\text { Número } \\
\text { de } \\
\text { amostras }\end{array}$ & $\begin{array}{c}\text { Identificação } \\
\text { da Amostra }\end{array}$ & Nome popular & Nome científico & $\begin{array}{c}\text { Data da } \\
\text { coleta }\end{array}$ & Local & Resultados \\
\hline 191. & $91 / 07$ & pinguim-antártico & Pygoscelis antarctica & $08 / 12 / 2007$ & $\begin{array}{l}\text { Ilha } \\
\text { Elefante/Antártica }\end{array}$ & Neg. \\
\hline 192. & $92 / 07$ & pinguim-antártico & Pygoscelis antarctica & $08 / 12 / 2007$ & $\begin{array}{l}\text { Ilha } \\
\text { Elefante/Antártica }\end{array}$ & Neg. \\
\hline 193. & $93 / 07$ & pinguim-antártico & Pygoscelis antarctica & $08 / 12 / 2007$ & $\begin{array}{l}\text { Ilha } \\
\text { Elefante/Antártica }\end{array}$ & Neg. \\
\hline 194. & $94 / 07$ & pinguim-antártico & Pygoscelis antarctica & $08 / 12 / 2007$ & $\begin{array}{l}\text { Ilha } \\
\text { Elefante/Antártica }\end{array}$ & Neg. \\
\hline 195. & $95 / 07$ & pinguim-antártico & Pygoscelis antarctica & $08 / 12 / 2007$ & $\begin{array}{l}\text { Ilha } \\
\text { Elefante/Antártica }\end{array}$ & Neg. \\
\hline 196. & $96 / 07$ & pinguim-antártico & Pygoscelis antarctica & $08 / 12 / 2007$ & $\begin{array}{l}\text { Ilha } \\
\text { Elefante/Antártica }\end{array}$ & Neg. \\
\hline 197. & $97 / 07$ & pinguim-rei & $\begin{array}{l}\text { Aptenodytes } \\
\text { patagonicus }\end{array}$ & $08 / 12 / 2007$ & $\begin{array}{l}\text { Ilha } \\
\text { Elefante/Antártica }\end{array}$ & $\mathrm{Neg}$ \\
\hline 198. & $98 / 07$ & pinguim-rei & $\begin{array}{l}\text { Aptenodytes } \\
\text { patagonicus }\end{array}$ & $08 / 12 / 2007$ & $\begin{array}{l}\text { Ilha } \\
\text { Elefante/Antártica }\end{array}$ & Negr \\
\hline 199. & $01 / 08$ & pinguim-adélia & Pygoscelis adeliae & $03 / 12 / 2008$ & Frente EACF & Neg. \\
\hline 200. & 02/08 & pinguim-adélia & Pygoscelis adeliae & $03 / 12 / 2008$ & Frente EACF & Neg. \\
\hline 201. & 03/08 & pinguim-adélia & Pygoscelis adeliae & $03 / 12 / 2008$ & Frente EACF & Neg. \\
\hline 202. & $04 / 08$ & pinguim-papua & Pygoscelis papиа & $03 / 12 / 2008$ & Frente EACF & Neg. \\
\hline 203. & 05/08 & pinguim-papua & Pygoscelis papua & $03 / 12 / 2008$ & Frente EACF & Neg. \\
\hline 204. & 06/08 & pinguim-adélia & Pygoscelis adeliae & $03 / 12 / 2008$ & Frente EACF & Neg. \\
\hline 205. & $07 / 08$ & pinguim-adélia & Pygoscelis adeliae & $03 / 12 / 2008$ & Frente EACF & Neg. \\
\hline 206. & 08/08 & pinguim-papua & Pygoscelis papua & $03 / 12 / 2008$ & Frente EACF & Neg. \\
\hline 207. & 09/08 & pinguim-papua & Pygoscelis papua & $03 / 12 / 2008$ & Frente EACF & Neg. \\
\hline 208. & $10 / 08$ & pinguim-antártico & Pygoscelis antarctica & $03 / 12 / 2008$ & Frente EACF & Neg. \\
\hline 209. & $11 / 08$ & pinguim-papua & Pygoscelis papua & $03 / 12 / 2008$ & Frente EACF & Neg. \\
\hline 210. & $12 / 08$ & pinguim-antártico & Pygoscelis antarctica & $03 / 12 / 2008$ & Frente EACF & Neg \\
\hline 211. & $13 / 08$ & pinguim-adélia & Pygoscelis adeliae & $03 / 12 / 2008$ & Frente EACF & Neg. \\
\hline 212. & $14 / 08$ & pinguim-adélia & Pygoscelis adeliae & $03 / 12 / 2008$ & Frente EACF & Neg. \\
\hline 213. & $15 / 08$ & pinguim-papua & Pygoscelis papua & $03 / 12 / 2008$ & Frente EACF & Neg. \\
\hline 214. & $16 / 08$ & pinguim-papua & Pygoscelis papua & $04 / 12 / 2008$ & Frente EACF & Neg. \\
\hline
\end{tabular}


(continuação)

\begin{tabular}{|c|c|c|c|c|c|c|}
\hline $\begin{array}{c}\text { Número } \\
\text { de } \\
\text { amostras }\end{array}$ & $\begin{array}{c}\text { Identificação } \\
\text { da Amostra }\end{array}$ & Nome popular & Nome científico & $\begin{array}{c}\text { Data da } \\
\text { coleta }\end{array}$ & Local & Resultados \\
\hline 215. & $17 / 08$ & pinguim-adélia & Pygoscelis adeliae & $04 / 12 / 2008$ & Frente EACF & Neg. \\
\hline 216. & $18 / 08$ & pinguim-papua & Pygoscelis papua & $04 / 12 / 2008$ & Frente EACF & Neg. \\
\hline 217. & $19 / 08$ & pinguim-adélia & Pygoscelis adeliae & $04 / 12 / 2008$ & Frente EACF & Neg. \\
\hline 218. & $20 / 08$ & pinguim-papua & Pygoscelis papua & $04 / 12 / 2008$ & Frente EACF & Neg. \\
\hline 219. & $21 / 08$ & pinguim-adélia & Pygoscelis adeliae & $04 / 12 / 2008$ & Frente EACF & Neg. \\
\hline 220. & $22 / 08$ & pinguim-adélia & Pygoscelis adeliae & $04 / 12 / 2008$ & Frente EACF & Neg. \\
\hline 221. & $23 / 08$ & pinguim-adélia & Pygoscelis adeliae & $04 / 12 / 2008$ & Frente EACF & Neg. \\
\hline 222. & $24 / 08$ & pinguim-adélia & Pygoscelis adeliae & $04 / 12 / 2008$ & Frente EACF & Neg. \\
\hline 223. & $25 / 08$ & pinguim-papua & Pygoscelis papua & $04 / 12 / 2008$ & Frente EACF & Neg. \\
\hline 224. & $26 / 08$ & pinguim-adélia & Pygoscelis adeliae & $05 / 12 / 2008$ & Punta Plaza & Neg \\
\hline 225. & $27 / 08$ & pinguim-adélia & Pygoscelis adeliae & $05 / 12 / 2008$ & Punta Plaza & $\mathrm{Neg}$ \\
\hline 226. & $28 / 08$ & pinguim-adélia & Pygoscelis adeliae & $05 / 12 / 2008$ & Punta Plaza & Neg. \\
\hline 227. & $29 / 08$ & pinguim-adélia & Pygoscelis adeliae & $05 / 12 / 2008$ & Punta Plaza & Neg. \\
\hline 228. & $30 / 08$ & pinguim-adélia & Pygoscelis adeliae & $05 / 12 / 2008$ & Punta Plaza & Neg. \\
\hline 229. & $31 / 08$ & pinguim-adélia & Pygoscelis adeliae & $05 / 12 / 2008$ & Punta Plaza & Neg. \\
\hline 230. & $32 / 08$ & pinguim-adélia & Pygoscelis adeliae & $05 / 12 / 2008$ & Punta Plaza & Neg. \\
\hline 231. & $33 / 08$ & pinguim-papua & Pygoscelis рариа & $05 / 12 / 2008$ & Punta Plaza & Neg. \\
\hline 232. & $34 / 08$ & pinguim-papua & Pygoscelis papua & $05 / 12 / 2008$ & Punta Plaza & Neg. \\
\hline 233. & $35 / 08$ & pinguim-adélia & Pygoscelis adeliae & $05 / 12 / 2008$ & Punta Plaza & Neg. \\
\hline 234. & $36 / 08$ & pinguim-papua & Pygoscelis papua & $06 / 12 / 2008$ & Frente EACF & Neg. \\
\hline 235. & $37 / 08$ & pinguim-adélia & Pygoscelis adeliae & $06 / 12 / 2008$ & Frente EACF & Neg. \\
\hline 236. & $38 / 08$ & pinguim-antártico & Pygoscelis antarctica & $06 / 12 / 2008$ & Frente EACF & Neg. \\
\hline 237. & $39 / 08$ & pinguim-adélia & Pygoscelis adeliae & $06 / 12 / 2008$ & Frente EACF & Neg. \\
\hline 238. & $40 / 08$ & pinguim-adélia & Pygoscelis adeliae & $06 / 12 / 2008$ & Frente EACF & Neg. \\
\hline
\end{tabular}


(continuação)

\begin{tabular}{|c|c|c|c|c|c|c|}
\hline $\begin{array}{c}\text { Número } \\
\text { de } \\
\text { amostras }\end{array}$ & $\begin{array}{c}\text { Identificação } \\
\text { da Amostra }\end{array}$ & Nome popular & Nome científico & $\begin{array}{c}\text { Data da } \\
\text { coleta }\end{array}$ & Local & Resultados \\
\hline 239. & $41 / 08$ & pinguim-adélia & Pygoscelis adeliae & $06 / 12 / 2008$ & Frente EACF & Neg. \\
\hline 240. & $42 / 08$ & pinguim-adélia & Pygoscelis adeliae & $06 / 12 / 2008$ & Frente EACF & Neg. \\
\hline 241. & $43 / 08$ & pinguim-antártico & Pygoscelis antarctica & $06 / 12 / 2008$ & Frente EACF & Neg. \\
\hline 242. & $44 / 08$ & pinguim-adélia & Pygoscelis adeliae & $06 / 12 / 2008$ & Frente EACF & Neg. \\
\hline 243. & $45 / 08$ & pinguim-adélia & Pygoscelis adeliae & $06 / 12 / 2008$ & Frente EACF & Neg. \\
\hline 244. & $46 / 08$ & pinguim-adélia & Pygoscelis adeliae & $06 / 12 / 2008$ & Frente EACF & Neg. \\
\hline 245. & $47 / 08$ & pinguim-antártico & Pygoscelis antarctica & $06 / 12 / 2008$ & Frente EACF & Neg. \\
\hline 246. & $48 / 08$ & pinguim-adélia & Pygoscelis adeliae & $06 / 12 / 2008$ & Frente EACF & Neg. \\
\hline 247. & $49 / 08$ & pinguim-adélia & Pygoscelis adeliae & $09 / 12 / 2008$ & Frente EACF & Neg \\
\hline 248. & $50 / 08$ & pinguim-adélia & Pygoscelis adeliae & 09/12/2008 & Frente EACF & Neg. \\
\hline 249. & $51 / 08$ & pinguim-papua & Pygoscelis papua & $09 / 12 / 2008$ & Frente EACF & Neg. \\
\hline 250. & $52 / 08$ & pinguim-adélia & Pygoscelis adeliae & $09 / 12 / 2008$ & Frente EACF & Neg. \\
\hline 251. & $53 / 08$ & pinguim-adélia & Pygoscelis adeliae & $09 / 12 / 2008$ & Frente EACF & Neg. \\
\hline 252. & $54 / 08$ & pinguim-adélia & Pygoscelis adeliae & $09 / 12 / 2008$ & Frente EACF & Neg. \\
\hline 253. & $55 / 08$ & pinguim-adélia & Pygoscelis adeliae & $10 / 12 / 2008$ & Frente EACF & Neg \\
\hline 254. & $56 / 08$ & pinguim-papua & Pygoscelis papua & $10 / 12 / 2008$ & Frente EACF & Neg. \\
\hline 255. & $57 / 08$ & pinguim-adélia & Pygoscelis adeliae & $10 / 12 / 2008$ & Frente EACF & Neg. \\
\hline 256. & $58 / 08$ & pinguim-adélia & Pygoscelis adeliae & $10 / 12 / 2008$ & Frente EACF & Neg \\
\hline 257. & $59 / 08$ & pinguim-adélia & Pygoscelis adeliae & $10 / 12 / 2008$ & Frente EACF & Neg. \\
\hline 258. & $60 / 08$ & pinguim-adélia & Pygoscelis adeliae & $10 / 12 / 2008$ & Frente EACF & Neg. \\
\hline 259. & $61 / 08$ & pinguim-adélia & Pygoscelis adeliae & $11 / 12 / 2008$ & Frente EACF & Neg. \\
\hline 260. & $62 / 08$ & pinguim-papua & Pygoscelis papиа & $11 / 12 / 2008$ & Frente EACF & Neg. \\
\hline 261. & $63 / 08$ & pinguim-papua & Pygoscelis papua & $11 / 12 / 2008$ & Frente EACF & Neg. \\
\hline 262. & $64 / 08$ & pinguim-adélia & Pygoscelis adeliae & $11 / 12 / 2008$ & Frente EACF & Neg. \\
\hline
\end{tabular}


(conclusão)

\begin{tabular}{|c|c|c|c|c|c|c|}
\hline $\begin{array}{c}\text { Número } \\
\text { de } \\
\text { amostras }\end{array}$ & $\begin{array}{l}\text { Identificação } \\
\text { da Amostra }\end{array}$ & Nome popular & Nome científico & $\begin{array}{c}\text { Data da } \\
\text { coleta }\end{array}$ & Local & Resultados \\
\hline 263. & $65 / 08$ & pinguim-antártico & Pygoscelis antarctica & $11 / 12 / 2008$ & Frente EACF & $\mathrm{Neg}$ \\
\hline 264. & $66 / 08$ & pinguim-adélia & Pygoscelis adeliae & $11 / 12 / 2008$ & Frente EACF & Neg. \\
\hline 265. & $67 / 08$ & pinguim-antártico & Pygoscelis antarctica & $11 / 12 / 2008$ & Frente EACF & Neg. \\
\hline 266. & $68 / 08$ & pinguim-adélia & Pygoscelis adeliae & $11 / 12 / 2008$ & Frente EACF & Neg. \\
\hline 267. & $69 / 08$ & pinguim-papua & Pygoscelis papua & $12 / 12 / 2008$ & Punta Plaza & Neg. \\
\hline 268. & $70 / 08$ & pinguim-adélia & Pygoscelis adeliae & $12 / 12 / 2008$ & Punta Plaza & Neg. \\
\hline 269. & $71 / 08$ & pinguim-papua & Pygoscelis papиа & $12 / 12 / 2008$ & Punta Plaza & Neg. \\
\hline 270. & $72 / 08$ & pinguim-adélia & Pygoscelis adeliae & $12 / 12 / 2008$ & Punta Plaza & Neg \\
\hline 271. & $73 / 08$ & pinguim-adélia & Pygoscelis adeliae & $12 / 12 / 2008$ & Punta Plaza & Neg. \\
\hline 272. & $74 / 08$ & pinguim-adélia & Pygoscelis adeliae & $12 / 12 / 2008$ & Punta Plaza & Neg. \\
\hline 273. & $75 / 08$ & pinguim-antártico & Pygoscelis antarctica & 09/03/2009 & Punta Plaza-Ipanema & Neg. \\
\hline 274. & $76 / 08$ & pinguim-antártico & Pygoscelis antarctica & 09/03/2009 & Punta Plaza-Ipanema & Neg. \\
\hline 275. & $77 / 08$ & pinguim-antártico & Pygoscelis antarctica & 09/03/2009 & Punta Plaza-Refúgio1 & Neg. \\
\hline 276. & $78 / 08$ & pinguim-antártico & Pygoscelis antarctica & 09/03/2009 & $\begin{array}{l}\text { Punta Plaza-Refúgio } \\
1\end{array}$ & Neg. \\
\hline 277. & $79 / 08$ & pinguim-papua & Pygoscelis pариа & 09/03/2009 & $\begin{array}{l}\text { Punta Plaza-Refúgio } \\
1\end{array}$ & Neg. \\
\hline 278. & $80 / 08$ & pinguim-antártico & Pygoscelis antarctica & 09/03/2009 & $\begin{array}{l}\text { Punta Plaza-Refúgio } \\
1\end{array}$ & Neg. \\
\hline 279. & $143 / 08$ & pinguim-papua & Pygoscelis papиа & $16 / 03 / 2009$ & Módulo de Química & Neg. \\
\hline 280. & $145 / 08$ & pinguim-papua & Pygoscelis papua & $17 / 03 / 2009$ & Módulo de Química & Neg. \\
\hline 281. & $146 / 08$ & pinguim-papua & Pygoscelis papua & $17 / 03 / 2009$ & Módulo de Química & Neg. \\
\hline 282. & $147 / 08$ & pinguim-papua & Pygoscelis pариа & $17 / 03 / 2009$ & Módulo de Química & Neg. \\
\hline 283. & $149 / 08$ & pinguim-papua & Pygoscelis papua & $17 / 03 / 2009$ & Módulo de Química & Neg. \\
\hline
\end{tabular}

